\title{
Hodgkin's disease: pursuing the progenitor cell
}

Citation for published version (APA):

Jansen, M. P. H. M. (1998). Hodgkin's disease: pursuing the progenitor cell. [Doctoral Thesis, Maastricht University]. Datawyse / Universitaire Pers Maastricht. https://doi.org/10.26481/dis.19981125mj

Document status and date:

Published: 01/01/1998

DOI:

10.26481/dis.19981125mj

Document Version:

Publisher's PDF, also known as Version of record

\section{Please check the document version of this publication:}

- A submitted manuscript is the version of the article upon submission and before peer-review. There can be important differences between the submitted version and the official published version of record.

People interested in the research are advised to contact the author for the final version of the publication, or visit the DOI to the publisher's website.

- The final author version and the galley proof are versions of the publication after peer review.

- The final published version features the final layout of the paper including the volume, issue and page numbers.

Link to publication

\footnotetext{
General rights rights.

- You may freely distribute the URL identifying the publication in the public portal. please follow below link for the End User Agreement:

www.umlib.nl/taverne-license

Take down policy

If you believe that this document breaches copyright please contact us at:

repository@maastrichtuniversity.nl

providing details and we will investigate your claim.
}

Copyright and moral rights for the publications made accessible in the public portal are retained by the authors and/or other copyright owners and it is a condition of accessing publications that users recognise and abide by the legal requirements associated with these

- Users may download and print one copy of any publication from the public portal for the purpose of private study or research.

- You may not further distribute the material or use it for any profit-making activity or commercial gain

If the publication is distributed under the terms of Article $25 \mathrm{fa}$ of the Dutch Copyright Act, indicated by the "Taverne" license above, 
Hodgkin's disease:

Pursuing the progenitor cell 
(CMPHM Jansen, Maastricht 1998

Maastricht: Universitaire Pers Maastricht. ISBN 90-5278-241-5 


\title{
Hodgkin's disease: Pursuing the progenitor cell.
}

\author{
Proefschrift
}

\author{
ter verkrijging van de graadl van doctor \\ aan de Universiteit Maastricht, \\ op gezag van de Rector Magnificus, \\ Prof. Dr. A Nieuwenhuijzen Kruseman \\ volgens het besluit van het College van Decanen, \\ in het openbaar te verdedigen \\ op woensdag 25 november 1998 om 14.00 uur
}

door

Mauritius Paulus Henricus Maria Jansen

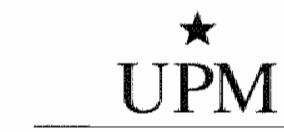

UNIVERSTARE PERS MAASTRICHT 


\section{Promotores:}

Prof. dr. FCS Ramaekers

\section{Co-promotor:}

Dr. HC Schouten

Dr. FJ Bot

\section{Beoordelingscommissie:}

Prof. dr. JPM Geraedts (voorzitter)

Prof. dr. MJAP Daemen

Prof. dr. V Diehl (Universität Köln, Deutschland)

Prof. dr. S Poppema (Rijksuniversiteit Groningen)

Prof. dr. J Wagstaff

This thesis was financially supported by the Ank van? Vlissingen Foundation and NijbakkerMora Foundation. 


Chapter 1 Introduction

Chapter 2 A novel triple-color detection procedure for brightfield microscopy, combining in situ hybridization with immunocytochemistry.

Chapter 3 Comparison of A- and B-type lamin expression in nodular sclerosing Hodgkin's disease and reactive lymph nodes.

Chapter 4 Chromosomal abnormalities in Hodgkin"s disease are not restricted to Hodgkin/Reed-Sternberg cells.

Chapter 5 Morphologically normal, CD30 negative B-lymphocytes with chromosome aberrations in classical Hodgkin's disease: The progenitor cell of the malignant clone?

Chapter 6 Genotyping and phenotyping of distinct cell populations in the Hodgkin-derived cell line L1236 provides evidence for progressive in vitro differentiation of precursor cells into Hodgkin/Reed-Sternberg-like cells.

Chapter $7 \quad$ Summary and General Discussion

Samenvatting

Dankwoord 



\title{
Chapter 1
}

\author{
Introduction
}


Hodgkin's disease is a malignancy of the lymph node which was first described as such in 1832 by Thomas Hodgkin 35 ! The tumor cells in Hodgkin's disease, first recognized by Reed ${ }^{[a !}$ and Sternberg ${ }^{155 !}$ around the turn of this century, have a distinct morphology, i.e. large mononucleated or multinucleated cells with prominent nucleoli. These cells, that make up only a smail proportion of the tumor, are called Hodgkin cells and Reed-Sternberg cells, respectively. Less than $1 \%$ of the cells in the Lumor area consists of the mallignant Hodgkin/ Feed-Sternberg cell population. Despite their rarity, Hodgkin/Reed-Sternberg cells appear to facilitate profound paraneoplastic effects such as weight loss, fever, pruritus, eosinophilia, and altered immune function [is!

Hodgkin/Reed-Sternberg cells and the hyper-reactive and inflammatory cellular reaction in their surroundings consisting of lymphocytes, histiocytes, granulocytes, eosinophils, plasma cells and stromal cells ${ }^{10, * 6]}$ are used for the diagnosis of four histological subtypes of Hodgkin's disease. These subtypes are described in the Rye-classification of $1966^{[62,631}$ and in a revised classification (REAL) of $1994^{[33]}$ as the nodular sclerosis, the mixed cellularity, the lymphocyte depleted and the lymphocyle predominant subtype. Nowadays, the lymphocyte predominant subtype is considered a distinct entity of Hodgkin's disease, whereas nodular sclerosis, mixed cellularity and lymphocyte depleted are collec-

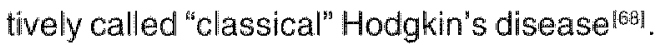

World-wide incidence rates for Hodgkin's disease are low and range between 1.5 and 4.5 for men and between 0.9 and 3.0 for women per one hundred thousand [2]]. The occurrence has an unusual age pattern, describing bimodal curves for two or three age-defined, etiologically distinct disease processes ${ }^{166 j}$. Epidemiological studies identify an age-defined association of Epstein-Barr virus infection with Hodgkin's disease ${ }^{[14,43]}$. Furthermore, incidence rates are also influenced by genetic susceptibility factors, as indicated by incidence variation among race ${ }^{[14.64]}$, by familial aggregation of the disease ${ }^{[28.65]}$, and by association with human leukocyte antigen (HLA) expression ${ }^{[53]}$.

The prognosis of Hodgkin's disease was poor until the mid-20 century. In the last four decades this prognosis has been substantially improved due to radio- and chemotherapy, resulting in tumor free survival rates after five years of $80 \%$ and $58 \%$ for the early and advanced stages of the disease, respectively ${ }^{[17]}$. Early stages of Hodgkin's disease are normally treated with radiotherapy ${ }^{[69]}$, whereas intermediate and advanced stages are treated with a combination of radio- and chemotherapy 192. The protocols of which are constantly adjusted to improve the tumor free intervals and survival rates and to reduce treatment related complications ${ }^{119 !}$.

\section{Hodgkin/Reed-Sternberg Cells}

The pathogenesis of Hodgkin's disease and the origin and nature of the malignant Hodgkin/ Reed-Stemberg cells still remain largely unknown. The phenotypic and genetic constitution of the Hodgkin/Reed-Sternberg cells has, therefore, been analyzed extensively in the last decades in an attempt to elucidate their origin and nature.

\section{Phenotypic constitution}

Immunocytochemical procedures have been used for the phenotypic analysis of the Hodgkin/Reed-Sternberg cell. Markers specific for different cell lineages were investi- 
gated to determine the origin of this malignant fraction, whereas markers specific for (lymphocyte) activation, proliferation, and apoptosis were analyzed to resolve the differentiation status of the tumor cells.

Cell lineage markers: Positivity for different lineage specific markers was observed, indlcating that the Hodgkin/Reed-Sternberg cells might originate from macrophages/histio-

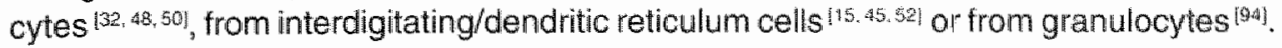
However, most studies indicated that the Hodgkin/Reed-Sternberg cells were derived from lymphocytes $\{9,23,42 !$. The B-cell markers CD 19, CD20, CD22, and CD79 and the T-cell markers $\mathrm{CD} 2, \mathrm{CD} 3, \mathrm{CD} 4, \mathrm{CD} 5, \mathrm{CD} 6, \mathrm{CD} 7$, and $\mathrm{CD} 8$ have been analyzed in the different

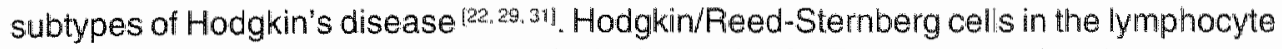
predominant subtype were almost exclusively positive for B-cell markers ${ }^{[6]}$. Furthermore, the tumor cells in this subtype also contain the B-cell specific J chain ${ }^{1923}$, another indication for their B-cell arigin ${ }^{78.99 !}$. Hodgkin/Reed-Sternberg cells in the classical subtypes express both B- and T-cell markers, however less frequently and distinctly, therefore hampering the exact determination of the founder phenotype [1. 12.25].

Activation markers: Different activation markers, such as CD15, CD30, CD40, CD70, and $\mathrm{MHC}$ classes I and II are expressed in the majority of Hodgkin/Reed-Sternberg cells [22, 29, 31]. Antibodies against the CD30-antigen are used in the classical subtypes as a phenotypic marker for Hodgkin/Reed-Sternberg cells, since in Hodgkin's disease this antigen is primarily detected in the malignant cells ${ }^{[8] 1}$. The tumor cells in the majority of lymphocyte predominant subtype lack the CD15 and CD30 antigen ${ }^{931}$. The CD30-antigen was also observed on a small subset of B-and T-lymphocytes, but these cells were not considered to be precursors of the Hodgkin/Reed-Sternberg cells ${ }^{[39]}$.

Proliferation markers: The proliferation markers Ki-67 and PCNA have been observed in Hodgkin's disease ${ }^{[39]}$, in the mononucleated Hodgkin cells and in the multinucleated ReedSternberg cells, although at a low frequency ${ }^{15.26)}$. Furthermore, the tumor cells expressed high levels of the oncogenes $c$-fos and $c$-jun which are linked with proliferation ${ }^{13}, 22,29$ and they incorporate ${ }^{3} \mathrm{H}$-thymidine into their nuclear DNA $[47]$, indicating that DNA synthesis does occur in Hodgkin/Reed-Sternberg cells. It appears in multinucleated Reed-Sternberg cells that all nuclei within the one cell are in the same phase of mitotic division, which may fit with the hypothesis that not cell fusion but endoreduplication without a cytoplasmic division causes this polykaryon formation ${ }^{[22]}$.

(Anti) Apoptotic markers: Several markers involved in the (anti) apoptotic processes, such as bcl-2, bcl- $x$, bax, and fas have been detected in Hodgkin's disease $19,01,71,84,4111$. The balance between cell death inducing (bax, fas) and protecting (bcl-2, bcl-x) proteins controls the apoptotic pathway. Bcl-2 and bcl-x are expressed in more than $50 \%$ of the Hodgkin/ Reed-Sternberg cells [21,29, 61,71. 84. Bax and fas are, however, also frequently obserwed in

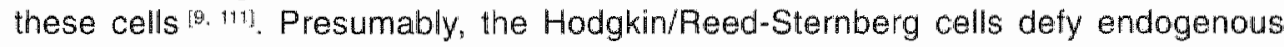
apoptosis through favouring cell death protecting proteins ${ }^{171 !}$. Furthermore, the $\mathrm{p} 53$ protein was detected in Hodgkin/Reed-Sternberg cells and presumed to correlate with a mutated protein which blocks the apoptotic pathway ${ }^{[21,30,77]}$. However, with the detection of the p53 protein no mutations were involved as previously postulated [102. 112], not relating hence, the presence of the $p 53$ protein to the protection against cell death. 


\section{Genetic constitution}

Flow cytometry, karyotyping, in situ hybridization, and molecular genetic procedures have been applied for the genetic analysis of the Hodgkin/Reed-Stemberg cell. This genetic characterization of the tumor cells should reveal its nature but might also clarify the origin of Hodgkin/Reed-Stemberg cells.

DNA flow cytometry. Flow cytometry was used to determine the nuclear DNA content and the aneuploid cell fraction in Hodgkin's disease 37 . Altered DNA contents have been detected in a range of $61031 \%$ of cases $12,2,42$, . This wide range might be due to differences in technical and analytical procedures, the development of more sensitive flow cytometers in the last years or sampling differences . The DNA indices varied from 0.7 to 1.9 , but the majority of cases had a DNA index between 0.8 and $1.2[24.44,72\}$. Such indices agree with a gain or loss of up to 8 or 10 chromosomes $[7]$. Furthermore, in one study the aneuploid cell fraction surpassed $10 \%$ in the majority of the analyzed aneuploid cases, clearly exceeding the frequency of Hodgkin/Reed-Stemberg cells in these cases ${ }^{[24]}$.

Karyotyping:Karyotyping of metaphase spreads could characterize structural and/or numerical chromosomal aberrations. However, it was difficult to obtain reliable karyotypes from lymph nodes affected with Hodglkin's disease. From 321 cases investigated in different studies ${ }^{[4,11,20,22,96,97,98]}$, only 141 cases showed abnormal karyotypes. The majority of these karyotypes showed numerical abnormalities, i.e. predominantly hyperdiploidy. Chromosomes $2,5,9$, and 12 were most frequently gained, whereas chromosomes 13 , $15,21, X$ and $Y$ were most frequently lost. In addition, structural abnormalities were also detected. Chromosomes involved in these structural abnomalities were $1 p, 6 q, 11 q$, and 14q. Nevertheless, all these studies did not discover a specific numerical or structural chromosome abnormality for Hodgkin's disease. Furthermore, the cellular origin of the abnormal karyotypes could not be assessed. Only a few reports indicated that the abnormal karyotypes were derived from Hodgkin/Reed-Stemberg cells ${ }^{[54,79,85,95] \mid .}$

In situ hybridization: The in situ hybridization procedure can be applied for the analysis of metaphase spreads as well as interphase nuclei, and is suitable for the detection of viral genomes or structural and/or numerical chromosomal aberrations [36.38.60. 73]. Not onlly fresh but also frozen and paraffin embedded archival samples can be examined in brightfield or fluirescence microscopy, recently allowing the detection of multiple targets in one cell:91. 10:4. Furthermore, in situ hybridization can be combined with immunophenotyping in order to determine the cellular origin of a genetically affected cell190.103107.109!. In Hodgkin's disease, this combined immunophenotyping and in situ hybridization procedure has been applied to fresh biopsies and paraffin embedded sections. Numerical abnormalities for chromosomes $1,2,3,4,8,12,17, X$ and $Y$ were detected in CD30 positive Hodgkin/ Reed-Sternberg cells $174,80,105,1061$. Furthermore, in situ hybridization detected Epstein-Bar Virus (EBV) in the Hodgkin/Reed-Sternberg cells of the classical subtypes more often than in lymphocytes of a healthy population [34, 43, 101, 110].

Molecular genetics: When standard molecular genetic techniques were applied to samples of Hodgkin's disease the frequency of Hodgkin/Reed-Sternberg cells was below the threshold of sensitivity for the abnormalities tested and to the admixture of other cells ${ }^{18]}$. However, via micromanipulation it was possible to isolate single Hodgkin/Reed-Sternberg cells and to anallyze their genetic alterations after PCR amplification ${ }^{100}$. Immunoglobulin gene rearrangements were determined for single Hodgkin/Reed-Stemberg cells to 
assess their origin and clonality. Several studies demonstrated that the tumor cells in the lymphocyte predominant and classical subtypes contained these gene rearrangements, proving that Hodgkin/Reed-Sternberg cells originated from B-lymphocytes $116,40,41,55.56 .53$. 59. 67. It is now generally accepted that the fumor celis in Hodgkin's disease contain monoclonal $\mathrm{lgH}$ rearrangements ${ }^{40 \mathrm{i}}$, and therefore, this tumor is considered to be a Blymphocyte malignancy. Finally, sequence mutation analysis of the rearranged genes indicated that the Hodgkin/Reed-Sternberg cells are derived from (crippled) germinal centre cells, because only germinal centre cells contain frequently (unfavourable) mutations in their rearranged genes which are observed in the tumor cells $[6,49,57]$.

\section{Tumor cell development in Hodgkin's Disease}

The phenotypic and genetic constitution of the Hodgkin/Reed-Sternberg cells was used in iwo recent studies to describe tumor cell development in Hodgkin's disease. The first model was primarily based on phenotypic characteristics ${ }^{131 !}$ whereas the second model used predominantly recently obtained genetic characteristics ${ }^{[57]}$.

Tumor cell development in the first model starts with the suppression of the immune system (iatrogenic, viral), followed by EBV infection or bcl2 rearrangement in lymphoid precursor cells. After these events other genetic alterations may occur resulting in a clonal expansion of lymphoid cells with morphologic features of Hodgkin/Reed-Sternberg cells. Tumor cell development in the second model starts with the gain of mutations in germinal centre B-lymphocytes. In lymphocyte predominant Hodgkin's disease, a favourable mutam tion results in high affinity memory $B$ cells which can transform into Hodgkin/Reed-Sternberg cells. [b]. In classical Hodgkin's disease, a crippling mutation results in cell death for most cells. However, a small population may be rescued from apoptosis and transformed during their survival into Hodgkin/Reed-Sternberg cells ${ }^{\mid 4 !\}}$.

Both models imply the existence of progenitor cells for the Hodgkin/Reed-Sternberg cells. Morphologically normal cells in the tumor area might, therefore, be candidate progenitor cells.

\section{Progenitor cells}

Although there is now some evidence that the primary malignant event may take place in the follicie centre cell, limited data are available on the phenotypic and genotypic characteristics of these hypothetical precursor cells.

Two studies did notice that the development of EBV-associated tumors in SCID mice was dependent on the presence of EBV-positive non-neoplastic small Iymphocytes in patient

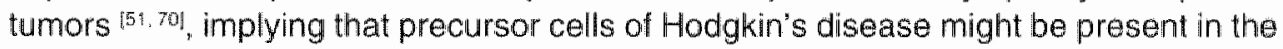
imorphologically normal cell population. Another study observed that Hodgkin/ReedSternberg cells in a Richter transformation of a chronic lymphocytic leukemia and in classical Hodgkin's disease share common genetic alterations, and that mature B cells could transform into cells with the morphology and immunophenotype of Hodgkin/Reed-Sternberg cells ${ }^{\mid 75}$. Finally, one study described abnormal karyotypes in Hodgkin's disease that did not correspond with the genetic constitution of their CD30-positive and morphologically typical Hodgkin/Reed-Stemberg cells ${ }^{105}$. These two latter studies suggest that genetic alterations already may occur in some morphologically normal precursor cells.

\section{Aim of this study}

We hypothesize that the malignant clone in Hodgkin's disease is not restricted to the Hodgkin/Reed-Sternberg cells, but also includes other cells. This, non-Hodgkin/Reed. 
Stemberg cell fraction also includes morphologically nomal progenitor cells. This is based on the above-mentioned circumstantial evidence and on the finding that DNA flow cytometry showed that the aneuploid cell fraction exceeded the population of Hodgkin/Reed-Sternberg cells. So far, however, not a single study has attempted to identify progenitor cells in Hodgkin's disease in the morphologically normal appearing cell population.

The aim of our study was to further define the malignant population and more specifically to identify the progenitor cells in Hodgkin's disease. For that reason, the phenotypic and genetic constitution of the morphologically normal cells in the tumor area was analyzed, in addition to the Hodgkin/Peed-Sternberg cells. A procedure for multiple target analysis in brightfield microscopy was developed for this pursuit (chapter 2) and used in a combination of immunophenotyping and in situ hybridization procedure (chapter 5). Lamin subtype expression patterns in combination with the Ki-67 marker were used to determine the differentiated versus proliferative phenotype of these cells (chapter 3). Numerical chromosome abnormalities were used to identify the genetically abnormal, i.e. malignant cell populations (chapter 4 and 5). The genetically aberrant cells were further characterized for lymphocyte subtype markers (chapter 5). Finally, a Hodgkin-derived cell line was analyzed in an attempt to further clarify tumor cell development in Hodgkin's disease and find support for the hypothesis that the malignant clone in Hodgkin's disease is not limited to the Hodgkin/ Reed-Sternberg cells, but also includes some morphologically normal B-lymphocytes which may be progenitor cells (chapter 6 ).

\section{References}

1. Agnarsson, B and Kadin, M. The immunophenotype of Reed-Sternberg cells: A study of 50 cases of Hodgkin's disease using fixed frozen tissues. Cancer 63: 2083 (1989).

2. Anastasi, J, Bauer, KD and Variakojis, D. DNA aneuploidy in Hodgkin's disease. A multiparameter flow-cytometric analysis with cytologic correlation. Am I Pathol 128: 573 (1987).

3. Angel, P and Karin, M. The role of Jun, Fos and the AP-1 complex in cell-proliferation and transformation. Biochim Biophys Acta 1072: $129(1991)$.

4. Banks, RE, Gledhill, S, Ross, FM, Krajewski, A, Dewar, AE and Weir-Thompson, EM. Karyotypic abnomalities and immunoglobulin gene rearrangements in Hodgkin's disease. Cancer Genet Crogenet 51 : $103(1991)$.

5. Bemjamin, $D$ and Gown, A. Aberrant cytoplasmic expression of proliferafing cell nuclear antigen in Hodgkin's disease. Am. Surg Pathor 15:764 (1991).

6. Braeuninger, A, Kuppers, $R$ "Strickler, J, Wacker, $H$, Rajewsky, Kand Hansmainn, M-L. Hodgkin and Roed Stemberg cells in lymphocyte predominant Hodgkin"s disease represent clonal populalions of geminal center-deriwed tumol cells. Proc Natl Acad Sci USA $94: 9337$ (1997).

7. Braylan, D, Benson, N and Nourse, V. Cellular DNA of human neoplastic B-Cells measured by flow cylometry. Cancer Res 44:5010 (1984).

8. Brimker, M, Poppema, S, Buys, C, Timens, W, Osinga, J and Visser, L. Clonal immunoglobulin gene rearrangements in tissues involved by Hodgkn's disease. Blood70: 186 (1987).

9. Brousset, P, Benharroch, D, Krajewski, S, Laurent, G, Meggetto, F, Rigal-Huguel, F, Gopas, J, Prinsloo, I, Pris, J. Delsol, G, Reed, J and Schlaifer, D. Frequent expression of the cell deathinducing gene bax in Reed-Stemberg cells of Hodgkin"s disease. Blood 87: 2470 (1996).

10. Burke, J. Hodgkin's disease: histopathology and differential diagnosis. In: D. Knowles, ed. Neoplastic Hematopathology. Baltimore: Williams \& Wilkins: 497 (1992).

11. Cabanillas, F, Pathak, S, Trujillo, J, Grant, G, Cork, A, Hagemeister, FB, Velasquez, WS, McLaughlin, P. Redman, J, Katz, A and al, e. Cylogenetic teatures of Hodgkin's disease suggest possible origin from a lymphocyle. Blood 71: 1615 (1988).

12. Casey, T, Olson, S, Cousar, J and Collins, R. Immunophenotypes of Reed-Sternberg cells: A study of 19 cases of Hodgkin's disease in plastic embedded sections. Blood 74:2624 (1989).

13. Cossman, J, Messineo, $C$ and Bagg, A. Reed-Sternberg cell: Survival in a hostile sea. Lab /mest 78 : $229(1998)$

14. Cozen. W, Katz, Jand Mack. T. Risk patterms of Hodgkin"s disease in Los Angeles vary by cell type. 
Cancer Epidemiology. Biomarkers and Prevention 1: 261 (1992).

15. Curran, R and Jones. E. Hodgkin's disease: An immunohistochemical and histological study. d Pathol 125: 39 (1978).

16. Delabie, J, Tierens, $A$, Wu, $G$, Weisenburger, D and Chan. W. Lymphocyte predominance Hodgkin's disease: lineage and clonality detentination using a single-cell assay. Blood $84: 3291(1994)$.

17. Diehl, $V$, Bredenfeld, $H$. Franklin, J and Jox, A. Hodgkin's disease in its second century. Helix $7: 36$ (1998).

18. Diehl, V Sieber, M, Ruffer, U, Lathan, B, Hasenclever, D, Pfreundschuh, M, Loeffler, M, Lieberz, $D$, Koch, $P$, Adler, M and Tesch, H. BEACOPP: an internsified chemotherapy reginen in advanced Hodgkin's disease. The Geman Hodgkin's Lymphoma Study Group. Ann Oncol 8: 143 (1997).

19. Dien, $V$, von Kalle, $C$, Fonatsch, $C$. Tesch. $H_{n}$ Juecker, M and Schadt, M. The cell of origin in Hodgkin's disease. Semin Oncol 17: 660 (1990).

20. Döhner, H, Bloomfield, CD. Frizzera, G, Frestedt, J and Arthur, DC. Recuning chromosome abnormalities in Hodgkin's disease. Genes Chromosom Cancer 5: 392 (1992).

21. Doussis, I. Pezzella, F, Lane, D, Gatter, K and Mason, D. An immunocytochemical study of 053 and bcl-2 protein expression in Hodgkin's disease. Am J Chir Pathol 99: 663 (1993)

22. Drexier, H. Recent results on the biology of Hodgkin and Reed-Stemberg cells, I. Biopsy material. Leuk Lymphoma 8: 283 (1992).

23. Drexler, H, Jones, D, Diehl, $V$ and Minowada, $J$ is the Hodgkin cell $a \mathrm{~T}$. or B.lymphocyte? Recent evidence from geno- and immunophenotypic analysis and in vitro cell lines. Hemalol Oncol7: 95 (1989).

24. Erdkamp, FL, Schouten, HC, Breed, WP, Janssen, WC, Hoffmann, JJ, Schutte "B and Blijham, GH DNA aneuploidy in Hodgkin's disease: a multiparameter flow cytometric analysis. Leuk Lymphomi 12: $297(1994)$.

25. Fatini, B, Stein, R, Pileri, S, Canino, S, Farabbi, R, Martelli, M, Grignani, F, Fagoli, M, Minelli, 0 . Ciani, $C$ and Flenghi, L. Expression of lymphoid-associated antigens on Hodgkin's and Feed-Sternberg cells in Hodgkin's disease. An immunocytochemical study on lymph node cytospins using mono. clonal antibodies. Histopathology 11: $1229(1987)$.

26. Gerdes, J, Baarlen, JW, Piler, S, Schwarting, $R_{\text {, Unnik, }} J$ and Stein, $H$. Tumor cell growth fraction in Hodgkin's disease. Am J Patho/ 129: 390 (1987).

27. Glaser, $S$ and Jarrett, $P$. The epidemiology of Hodgkin's disease. Ballieres Clin Hemato : $9(3): 401$ (1996).

28. Grufferman, Sand Delzell. E. Epidemiology of Hodgkin's disease. Epidem Rev 6: 76 (1984).

29. Gruss, H-J and Kadin. M. Pathophysiology of Hodgkin's disease: functional and molecular aspects. Ballieres Clin Hematol 9: 417 (1996).

30. Gupta, R, Norton, A, Thompson, ILister, T and Bodmer, J. p53 expression in Reed-Stemberg cells of Hodgkin's disease. Br J Cancer 66:649 (1992).

31. Haluska, F, Brutsky A and Canellos, G. The cellular biology of the Reed-Sternberg cell, Blood 8.4: $1005(1994)$.

32. Hansmann, M-L, Radzum, H, Nebendah, C and Pawwaresch, M. Immunoelectron-mictoscopic investigation of Hodgkin's disease with monoclonal antibodies against histiocyles. Eur J Hanmato/40: 25 (1988).

33. Harris, $N$, Jaffe, E, Stein, $H$, Banks, $P$, Chan, J, Cleary, $M$, Delsol, $G$, de Wolf Peetters, $C$, Falin, B, Gatter, K, Grogan, T, Isaacson, P, Knowles, D, Mason, D, Müller-Hermelink, H. Pileri, S, Piris, M, Rallikiaer. E and Warnke, R. A revised European-American classification of lymphoid neoplasms; a proposal from the international lymphoma study group. Blood 84: 1361 (1994)

34. Herbst, $H$, Stein, $H$ and Niedobitek, G. Epstein Barr virus and CD30* malignant lymphomas. Crit Rev Oncog 4: 191 (1993).

35. Hodgkin. T. On some morbid appearances of the absorbent glands and spleen. Med Chir Trans 17: $68(1832)$.

36. Hopman, A, Ramaekers, F, Raap, A, Beck, J, Devilee, P, van der Ploeg, M and Vooifs, G. In silu hybridization as a tool to study numerical chromosome aberrations in solid bladder tumors. His. tochemistry 89: 307 (1988).

37. Hopman, $\mathrm{AH}$, Voorter, $\mathrm{CE}$ and Ramaekers, FC. Detection of genomic changes in cancer by in silu hybridization. Mol Biol Rep 19: 31 (1994).

38. Hopman. AHM, Poddighe, P. Moesker, O and Famaekers, FCS. Interphase cytogenetics: an approach to the detection of genetic aberrations in tumours. Diagnostic Molecular Pathology - A prac tical approach. Oxford: IRL Press, Vol 1: 141 (1992).

39. Hsu; $S$ and Hsu, P. Aberrant expression of $T$ cell and $B$ cell markers in myelocyte-monocyte-histiocyte derived lymphoma and leukemia cells, Is the infrequent expression of T/B cell markers sufficient to establish a lymphoid origin for Hodgkin's Reed-Stemberg cells? Am J Pathol 134: 203 (1989). 
40. Hummel, M, Marafioti. T, Ziemann, K and Stein, H. Ig reartangements in isolated Reed-Sternberg cells: conclusions irom four different studies. Ann Oncol7 (Sup 4): 31 (1996).

4\%. Hummel, M. Zlemann, K, Lammert, H, Pileri, S, Sabattin, E and Stein, H. Hodgkin's disease with monoclonal and polyclonal populations of Reed-Sternberg cells. N Engl J Med 333: 901 (1995).

42. Jafte, E. The elusive Reed-Stemberg cell. N Engl J Med 320 : 529 (1989).

43. Jarrett, $R$, Armstrong, A and Alexander. F. Epstein-Barr virus and the epidemiology of Hodgkin's disease. Ann Oncol 7 (sup 4): $S 5$ (1996).

44. Joensuu, H, Klemi, PJ and Korkella, E. Prognostic value of DNA ploidy and proliferative activity in Hodgkin's disease. Am J Clin Pathol 90: 670 (1988).

45. Kadin, M. Possible origin of the Reed Sternberg cell from an interdigitating reticulum cell. Cancer Treat Rep 60: 601 (1982).

46. Kadin, M. Pathology of Hodgkin's disease. Current Opinion in Oncology 6: 456 (1994).

47. Kadin, Mand Astbury. A. Long term cultures of Hodgkin's tissue. A morphologic and radioautographic study. Lab /mvest 28: 81 (1973).

48. Kadin, $M$, Stites, $D$, Lewy, $\mathbb{R}$ and Warnke, $R$. Exogenous immunoglobutin and the macrophage origin of the Reed-Sternberg cels in Hodgkin's disease. N Engl U Med299: 1208 (1978).

49. Kanzler, H, Küppers, F, Hansmann, ML and Rajewsky, K. Hodgkin and Reed-Sternberg cells in Hodgkin's disease represent the outgrowth of a dominant tumor clone derived from (crippled) germinal center B cells. J Exp Med 184: 1495 (1996).

50. Kaplan, H and Gartner, 5. "Stemberg-Reed" giant cells of Hodgkin"s disease: Cultivation in vitro, heterotransplantation, and characterization as neoplastic macrophages. Int I Cancer 19:511 (1977).

51. Kapp, U, Wolf, J, Hummel, M, Pawlita, M, von-Kalle, $C_{n}$ Dallenbach, $F$, Schwonzen, M, Krueger, GR. Muller-Lantzsch, N, Fonatsch, $C$ and al, e. Hodgkin's lymphoma-derived tissue serially transplanted into severe combined immunodeficient mice. Blood B2: 1247 (1993).

52. Kennedy, $\|_{\sharp}$ Hart, D, Colls, B, Nimmo, ل, Willis, D and Angus, H. Nodular sclerosing, mixed cellularty and lymphocyte-depleted variants of Hodgkin's disease are probably dendritic cell malignancies. Clin Exp Immunol 76: 324 (1989).

53. Kitz, W, Aldrich, C, Fildes, N and al. e. Localization of predisposition to Hodgkin disease in the HLA class II region. Am J Hum Gen 54: 497 (1994).

54. Knuttlla, S, Teerenhovi, L, Larramendy, M, Elonen, E, Franssila, K, Nylund, S, Timonen, T, Heinonen, $K_{i}$ Mahlamaki. E, Winqvist, $\mathrm{F}$ and Ruutu, T. Cell Ineage involvement of recurrent chromosomal abnormalities in hematologic neoplasms. Genes Chromosom Cancer 10: 95 (1994).

55. Küppers, $R$, Hansmann, ML, Diehl, $V$ and Rajewsky, K. Mollecular single-cell analysis of Hodgkin and Heed-Sternberg cells. Mol Med Today 1:26 (1995).

56. Küppers, R, Kanzler, H, Hansmann, MLL and Rajewsky, K. Single cell analysis of Hodgkin/ReedStemberg cells. Ann Oncol7 (Sup 4): 27 (1996).

57. Küppers, $\mathrm{R}$ and Rajewsky, K. The origin of Hodgkin and Reed/Sternberg cells in Hodgkin's disease. Annu Rev Immunol 16: 471 (1998).

58. Küppers, R, Rajewsky, K, Zhao, M, Simons, G, Laumann, R, Fischer, R. and Hansmann, ML. Hodgkin's disease: clonallg gene rearrangements in Hodgkin and Reed-Sternberg cells picked from histological sections. Ann N Y Acad Soi 764: 523 (1995).

59. Leoncini, L, Spina, D, Meght, T, Gallorini, M, Tosi, P. Hummel, M, Stein, H, Pileri, S, Kraft, R, Laissilue, JA, and Cottier, H. Cell kinetics, morphology, and molecular IgVH gene rearrangements in Hodgkin's disease. Lauk Lymphoma 26: 307 (1997).

60. Lichter, $\mathrm{P}$ and Pied, T. Molecular analysis of chromosome aberrations. In situ hybridization. Methods Mol Biol 29: $449(1994)$.

61. Lormzen, J, Thiele, J and Fischer, R. The mummified Hodgkin cell: cell death in Hodgkin's disease. JPathol 182: 288 (1997).

62. Lukes, R and Butler, J. The pathology and nomenclature of Hodgkin's disease. Cancer 26: 1063 (1966).

63. Lukes, R, Gompel, L, Hall, T, Rappapon, $H$ and Rubin, P. Report of the Nomenclature Committee. Rye Classification. Cancer Res 26: 1311 (1966).

64. Macfarlane, G, Evstifeeva, T, Boyle, P and al, , e. International patterns in the occurence of Hodgkin's disease in children and young adull males. Int J Cancer61: 165 (1995).

65. Mack, T, Cozen. W, Shibata, D and al., e. Concordance for Hodgkin's disease in identical twins suggesting genetic susceptibility to the young-adult form of the disease. N Engl J Med 332. 413 (1995).

66. MacMahon, B. Epidemiology of Hodgkin's disease. Cancer Res 26: 1189 (1966).

67. Marafioti, T, Hummel, M, Anagnostopoulos, I, Foss, HD, Falini, B, Delsol, G, Isaacson, PG, Pileri, S and Stein, H. Origin of nodular lymphocyte-predominant Hodgkin's disease from a clonal expansion of highly mutated geminal-center B cells. NEngl J Med 337: 453 (1997). 
68. Mason, D, Banks, P, Chan, J, Cleary, M, Delsol, G, de Wolt-Peeters, C. Falini, B, Gatter, K, Gragan, T. Harris, N, Isaacson, P, Jaffe, E, Knowles, D, Müller-Hermeink, H, Plen, S, Ralfkaer, E, Stein, H and Warnke, R. Nodular Iymphocyte predominance Hodgkin's disease. A clinicopathological entity. Am J'Surg Pathol 18: 526 (1994).

69. Mauch, P. Management of early stage Hodgkin's disease: the role of radiation therapy and/or chemotherapy. Ann Oncol7: 79 (1996).

70. Meggetto, F, Muller, C, Henry, S, Selves, J, Mariame, B, Brousset, $P$, Saati, TA and Delsol, G. Epstein-Bart Virus (EBV)-associated lymphoproliferations in severe combined immunodefficient mice transplanted with Hodgkin's disease lymph nodes: Implication of EBV-positive bystander B lymphocytes rather than EBV-intected Reed-Stemberg cells. Blood87: 2435 (1996).

71. Messineo, $C$, Jamerson, M, Hunter, E, Braziel, R, Bagg, $A$, Ining, S and Cossman, J. Gene expression by single Reed-Stemberg cells: Pathways of apoptosis and activation. Blood;91:2443(1998).

72. Morgan, KG, Quirke, P, O'Brien, CJ and Bird, CC. Hodgkin"s disease: a flow cytometric study. J Chin Pathol 41: 365 (1988).

73. Nederlof, PM, van-der-Flier, S, Raap, AK, Tanke, HU, van-der-Ploeg, M, Konips, F and Geraedts, JP. Detection of chromosome aberrations in interphase tumor nuclei by nonradioactive in situ hybridiza. tion. Cancer Gene Cytogenet 42: 87 (1989).

74. Nolte, $M$, Werner, $M$, von Wasielewski, $R$, Nietgen, $G$, Wilkens, $L$ and Georgii, $A$, Detection of numerical karyotype changes in the giant cells of Hodgkin's lymphomas by a combination of FISH and immunohistochemistry applied to paraffin sections. Histochem Cell Biol 105: 401 (1996).

75. Ohno, T, Smir, B, Weisenburger, D, Gascoyne, R. Hinrichs, S and Chan, W. Origin of the Hodgkin/ Reed-Stemberg cells in chronic lymphocytic leukemia with "Hodgkin's transformation". Blood91: $1757(1998)$.

76. Pasman , P, Erdkamp, F, Breed, W, Janssen, W, Hoffmann, J, Schutte, B, Vrints, L and Schouten, $H$. Flow cytometric analysis of consecutive lymph node samples from patients with Hodgkin's disease: reproducible within one biopsy? Leuk Lymphoma 22: 339 (1996).

77. Pasman, PC, Tiebosch, A, Erdkamp, FL, Vrints, LW, Breed, WP and Schouten, HC, P53 as a marker of the malignant cell in Hodgkin's disease. Annals of Oncology 5 (Sup 1): $\$ 89$ (1994).

78. Pinkus, G and Said, J. Hodgkin's disease, lymphocyte predominance type, nodular-Funther evidence for a $B$ cell derivation. Am I Pathol 133: 211 (1988).

79. Poppema, S, Kalela, J and Hepperle, B. Chromosomal abnormalities in patients with Hodgkin's disease: evidence for frequent involvement of the $14 \mathrm{q}$ chromosomal region but infrequent bol-2 gene rearrangements in Reed-Sternberg cells. INatl Cancer /nst B4: 1789 (\$992).

80. Pringle, JH, Shaw, JA, Gillies, A and Lauder, I. Numerical chromosomal aberrations in Hodgkin's disease detected by in situ hybridisation on routine paraffin sections. J Clin Pathol 50: 553 (1997).

81. Reed, D. On the pathological changes in Hodgkin's disease, with special reference to its relationship to tuberculosis. J Hopkins Hosp Rep 10: 133 (1902).

82. Reuss, K, Engert, A, Tesch. H and Diehl, W. Current clinical trials in Hodgkin's disease. Ann Oncol 7: $109(1996)$.

83. Sabattini, E, Gerdes, J, Gherlimzoni, F, Poggi, S, Zucchini, L, Melili, G, Grigioni, F, Dolveconio, M, Leoncini, L. Falini, B and Pileri, S. Comparison between the monoctonal antibodies Ki- 67 and pcio in 125 malignant lymphomas. J Pathol 169: 397 (1993).

84. Schlaifer, D, March, M, Krajewski, S, Laurent, G, Pris, J, Delsol, G, Reed, J and Brousset, P. High expression of the bel-x gene in Reed-Stemberg cells of Hodgkin's disease. Blood85: 2671 (1995).

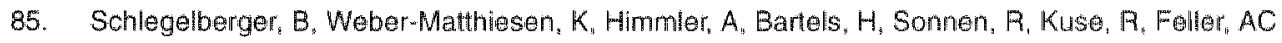
and Grote, W. Cytogenetic findings and results of combined immunophenotyping and karyotyping in Hodgkin's disease Laukemia 8: 72 (1994).

86. Schouten, H, Sanger, W, Duggan, M, Weisenburger, D, MacLennan, K and Armitage, J. Chromosomal abnormalities in Hodgkin's disease. Blood73: 2149 (1989).

87. Schutte, B, Reynders, M, Bosman, F and Bihnam, G. Flow cytometric determination of DNA ploidy level in nuclei isolated from paraffin-embedded tissue. Cytometry $6: 26,1985)$.

88. Schwab, U, Stein, H, Gerdes, J, Lemke, H, Kirchner, H. Schaadi, M and Diehl, V. Production of a monoclonal antibody specific for Hodgkin and Sternberg-Reed cells of Hodgkin's disease and subset of nomal lymphoid cells. Nature 299: 65 (1982).

89. Shackney, SE, Sikramstad KS, Cunningham, RE, Dugas, DJ, Lincoln, TL and Lukes, AJ. Dual parameter flow cytometry studies in human lymphomas. IClin Invest 66: 1281 (1980).

90. Speel, Ed, Herbergs, J, Ramaekers, FC and Hopman, AH. Combined immunocytochemistry and fluorescence in situ hybridization for simultaneous tricolor detection of cell cycle, genomic, and phenotypic parameters of tumor cells. I Histochem Cytochem 42: 961 (1994).

91. Spee, El, Jansen, MP, Riamaekers, FC and Hopman, AH. A novel triple-Color detection procedure for brightfield microscopy, combining in situ hybtidization with immunocytochemistry. J Histochem 
Cytochem 42: $1299(1994)$.

92. Sten, $H_{4}$, Hansmann, ML, Lennet, $K$, Brandzaeg, P, Gatter, $K$ and Mason, D. Reed-Sternberg and Hodgkin celis in lymphocyte-predominant Hodgkin's disease of nodular subtype contain J chain. Am J Clin Pathol 86: 292 (1986).

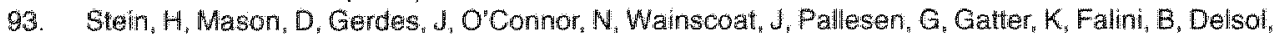
Q. Lemke, $H$, Schwarting, $R$ and Lennert. $K$. The expression of the Hodgkin's disease associated antigen Ki- 1 in reactive and neoplastic lymphoid tissue: Evidence that Reed-Stemberg cells and histiocytic malignancies are derived from activated lymphoid cells. Blood 66: 848 (1985).

94. Stein, H, Uchanska-Ziegler, B, Gerdes, $J$, Zlegler, A and Wernet, P. Hodgkin and Sternberg-Reed cells contain antigens specific lo late granulopoesis. Int $J$ Cancer 29: 283 (1982).

95. Stemberg, $\mathrm{C}$. Über eine eigenartige unter dem Bilde der Pseudoleukämie verlaufende Tuberkulose des lymphatischen Apparates. Z Heikunde 19: 21 (1898).

96. Teerenhovi, L, Lindholm, C. Pakkala, A, Franssila, $K$, Stein, $H$ and Knuutila, S. Unique display of a pathologic karyotype in Hodgkin's disease by Reed-Stemberg cells. Cancer Genet Cytogenet 34 : 305 (1988).

97. Thangavelu, Mand Le-Beau, MM. Chromosomal abnormalities in Hodgkin's disease. Hematol Oncol Clin North Am 3: 221 (1989).

98. Tilly,$H$, Bastard, C, Delastre, T, Duval, C, Bizet, M, Lenormand, B, Dauce, JP. Monconduit, M and Piguet, H. Cytogenetic studies in untreated Hodglkin's disease. Blood 77: 1298 (1991).

99. Timens, W, Visser $L$ and Poppema, S. Nodular subtype predominance type of Hodgkin"s disease is a germinal center lymphoma. Lab invest54: 457 (1986).

100. Trümper, L, Brady, G, Bagg, A, Gray, D, Loke, S, Greisser, H, Wagman, R, Braziel, R, Gascoyne, R, Vicini, $S$, Iscove, $N$, Cossman, J and Mak, T. Single-cell analysis of Hodgkin and Reed-Stemberg cells: Molecular heterogeinity of gene expression and p53 multations. Blood B1: 3097 (1993).

101. Vassallo, J, Brousset, P. Knecht, H, Lamant, L, Odermatt, BF and Deisol, G. Detection of EpsteinBarr virus in Hodgkin's disease. Applied immunohistochemistry 1:213 (1993).

102. Villuendlas, $R$, Pïris, M, Algara, P and al., $\Theta$. The expression of p53 protein in non Hodgkin's lymphow mas is not always dependent on $p 53$ gene mutations. Blood 82: 3151 (1993).

103. Weber-Matthiesen, K, Deerberg, J, Muller-Hermelink, A, Schlegelberger, B and Grote, W. Rapid immunophenotypic characterization of chromosomally aberrant cells by the new FICTION method. Cytogenet Cell Genet 63: 123 (1993).

104. Weber-Matthiesen, K, Deerberg, J, Muller-Hermelink, A, Winkemann, M, Schlegelberger, B and Giote. W. Rationalization of in situ hybridization: testing up to 16 different probes on a single slide. Cancer Genet Cytogenet 68: 91 (1993).

105. Weber-Matthiesen, $K_{1}$ Deerberg,, , Poetsch, M, Grate, W and Schlegelberger, B. Clarification of dubious karyotypes in Hodgkin's disease by simultaneous fluorescence immunophenotyping and interphase cytogenetics (FICTION). Cytogenet Cell Genet 70: 243 (1995).

106. Weber-Matthiesen, $K$, Deerberg, J, Poetsch, M, Grote, W and Schlegelberger, B. Numerical chromosome aberrations are present within the CD30 Hodgkin and Reed-Stemberg cells in $100 \%$ of analyzed cases of Hodgkin's disease. Blood 86: 1464 (1995).

107. Weber-Matthiesen, K, Muler-Hermelink, A, Deerberg, J, Scherthan, $H$, Schlegelberger, B and Grote, W. Discrimination of distinct subpopulations within a tumor with combined double immunophenotyping and interphase cytogenetics. I Histochem Cytochem $41: 164 \pi$ (1993)

108. Weber-Matthiesen, $K$, Pressi, $S$, Schlegelbenger, B and Grote. W. Combined immunophenotyping and interphase cytogenetics on cryostat sections by the new FICTION method. Leukemia 7:646 (1993).

109. Weber-Matthiesem, K, Winkemann, M, Muller-Hermelink, A, Schllegelberger, B and Grote, W. Simultaneous fworescence immunophenolyping and interphase cylogeneticsi a contribution to the characterization of tumor cells. J Histochem Cylochem 40: 171 (1992).

110. Weiss, LM, Movahed, LA, Warnke, RA and Sklar, J. Dettection of Epstein-Barr viral genomes in Reed-Sternberg cells of Hodgkin's disease. N Engl J Med 320: 502 (1989).

111. Xern, $L$. Carbuccia, N, Parc, P, Hassoun, $J$ and Birg. F. Frequent expression of FAS/APO-1 in Hodgkin's disease and anaplastic large cell lymphoma. Histopathology 27: 235 (1995).

112. Xeri, L, Parc, P, Bouabdallah, $R$, Camerolo, $J$ and Hassoun, J. PCR-mismatch analysis of p53 gene mutation in Hodgkin's disease. J Pathol 175: 189 (1995). 


\section{Chapter 2}

\section{A novel triple-color detection procedure for brightfield microscopy, combining in situ hybridization with immunocytochemistry}

Ernst JM Speel, Maurice PHM Jansen, Frans CS Ramaekers, and Anton HN Hopman

J Histochem Cytochem 42, 1299-1307, 1994 
Abstract

We describe a fast light microscopic procedure for the simultaneous enzyme cytochemical detection of three different DNA target sequences in contrasting colors in both interphase and metaphase cell preparations. Chromosome-specific DNA probes labeled with either biotin, digoxigenin, or fluorescein were hybridized as a mixture and detected clearly and accurately by precipitates of the horseradish peroxidase-diaminobenzidine (PO-DAB, brown color), alkaline phosphatase-Fast Red (APase-Fast Red, red color), or horseradish peroxidase-tetramethylbenzidine ( $P O-T M B$, green color) reaction, respectively. The $P O-T M B$ reaction product was stabilized effectively by the addition of sodium tugnstate to the reaction mixture, thus making the $\mathrm{PO}$-TMB reaction now generally applicable to in situ hybridization (ISH). To avoid mixing of the precipitates of the two PO reactions used in the triple-color ISH method, the first detected PO activity was always completely inactivated by a mild acid treatment before the second one was applied. Finally, the cell preparations were embedded in a thin protein layer cross-linked by formaldehyde to ensure permanent stabilization of the enzyme reaction products and optimal visualization of color contrast. The triple-color $1 \mathrm{SH}$ detection procedure could be combined with B-galactosidase-5-bromo4-chloro-3-indolyl-B-D-galactoside immunocytochemistry; leading to the simultaneous localization of multiple DNA targets and a protein target in the same cell. The described procedure may, therefore, be a valuable tool in the areas of cytogenetics, cell biology, and molecular pathology.

\section{Introduction}

Non-radioactive in situ hybridization (ISH) procedures using chromosome-specific DNA probes provide a powerful tool for the analysis of numerical and structural genomic aberrations in metaphase and interphase preparations of mammalian cells ${ }^{155}$, 19. Many nonradioactive detection systems have been described for $1 \mathrm{SH}$, of which the fluorescence and enzyme cytochemical procedures are most frequently used. These methods are based on visualization of in situ hybridized DNA probes, which are modified either directly ${ }^{[44]}$ or indirectly ${ }^{[16.27]}$ "with cytochemical detection layers of, for example, avidin and antibody conjugates carrying different tags for used in various types of microscopy ${ }^{18,23,24,31,33]}$. Since the intraduction of fluorescence $1 \mathrm{SH}$ by the end of the $1970 \mathrm{~s}^{[1.38]}$, this technique has been improved enormously and is now widely used because of its analytical speed and its high sensitivity and resolution [atil. Moreover, various fluorochromes are now available that allow simultaneous detection of multiple DNA target sequences in different colors in only one preparation ${ }^{\text {(3. } .13 .17,18.20)}$. Despite these advantages, fluorescence ISH has the disadvantage, that fading of the fluorescence signal takes place on exposure to light, aithough anti-fading reagents have been described that delay this proces to a large extent [?]. We have recently reported the application of the sensitive alkaline phosphatase (APase-)Fast Red reaction to $\mathrm{ISH}$, which results in a precipitate with a virtually permanent fluorescent character ${ }^{[34 !}$. However. a disadvantage of fluorescence ISH may also be the significant autofluorescence in, e.g., formalin-fixed, paraffin-embedded tissue sections. In addition, because of economical and practical considerations, the use of precipitating enzyme cytochemistry for ISH, combined with conventional brightfield microscopy, can be a valuable alternative to fluorescence $\mathrm{SH}$, especially, if permanent cell preparations with nondiffusable, non-fading reaction products can be combined with preservation of cell morphology.

Several authors have reported the successful application of double-target absorption ISH on cell preparations and tissue sections, utilizing both horseradish peroxidase (PO) and 
APase as the reporter enzymes $[0,9,13,17,18,20]$. In these cases, the two contrasting colors of the reaction products could be clearly distinguished by brightfield microscopy. In the fields of cytogenetics, molecular pathology, and cell biology, however, there is still an increasing need for techniques that allow demonstration of multiple targets (such as nucleic acid sequences) in the same specimens. Such a goal requires the use of different enzyme cytochemical reactions that possess both high sensitivity and precise localization properties and result in stable reaction products with contrasting colors. Moreover, rapid staining reactions are preferred so that the entire detection procedure can be performed within a few hours. The triple-staining protocols that have been described for immunocytochemistry $(I C C)^{16,38,39]}$ are unsuitable for ISH. First the localization properties of the B-gallactosidase-5-bromo-4-chloro-3-indolyl-B-D-galactoside ( $B$-Gal-BCIG) reaction in these proce-

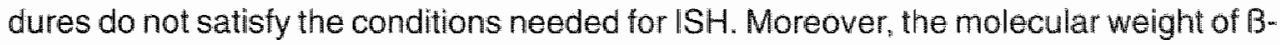
Gall is very high $(500 \mathrm{kD})$, as a result of which we have as yet been unsuccessful in utilizing B-Gal conjugates for ISH (Speel unpublished results). Second, in these ICC procedures, directly enzyme-labeled conjugates were used that may give rise to penetration problems if they are applied in the first ISH detection layer, resulting in diffuse, weak staining reactions ${ }^{[34]}$. Since specific nucleic acid probes can now be labeled with biotin, digoxigenin, and fluorescein, such differently modified probes hybridized to immobilized target nucleid acids have been visualized simultaneously by three different colors in blots (rainbow system, $\left.{ }^{(14)}\right)$. In this system, the detection was carried out in consecutive APase-based reactions using three different naphthol-phosphate/diazonium salt combinations. However "the feasibility of this detection system for use in ISH remains to be established.

In the underlying study, a novel and relatively fast triple-color ISH method was developed for use in brightfield microscopy. For this purpose, we combined two PO reactions (POdiaminobenzidine (DAB) and PO-tetramethylbenzidine (TMB)) with one APase reaction (APase-Fast Red), since these enzyme reactions have proven to meet the criteria for

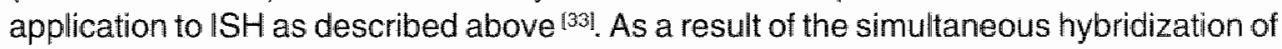
a biotinylated, a fluoresceinated, and a digoxigenin-labelled DNA probe, the DNA target sequences were detected accurately by means of the contrasting colors brown (PO-DAB), green ( $\mathrm{PO}-\mathrm{TMB}$ ), and red (APase-Fast Red). The application of the $\mathrm{PO}-\mathrm{TMB}$ reaction to ISH was described by us only recently ${ }^{[33]}$. This enzyme reaction, which is a modification of the procedure as described by Van der Loos et al. ${ }^{\text {Hol }}$, resulted in an unstable green precipitate. Only immediate air-drying after the reaction could preserve the green reaction product, whereas embedding of stained cell preparations in organic-based mounting media led to a change in the absorption color from green to purple. Therefore, we examined the efficacy of sodium tungstate to stabilize the PO-TMB reaction product, which was recently

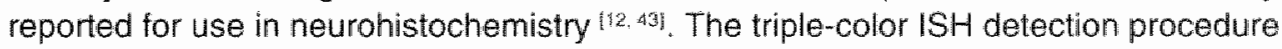
described here, in addition, could be combined with $B$-gal-BCIG ICC, providing a procedure for the simultaneous demonstration of one protein and three DNA targets in the same cell.

\section{Materials \& Methods}

Cell processing

Cell preparations from a $70 \%$ ethanol suspension of the human transitional cell carcinoma line T24 (DNA index 1.6; trisomic for the centromeres of chromosomes 1 and 7 , tetrasomic for the centromere of chromosome 17 and the telomere of chromosome $1 \mathrm{p} ;$; 411 , as well as steps necessary for removal of cytoplasm to improve DNA probe and conjugate penetration (pepsin digestion), were performed as previously described 115.34 . 
Human umbilical vein endothelial (HUVE) cells were grown on coated glass slides in a $1: 1$ mixture of M199 (Gibco-BRL, Breda, The Netherlands) and RPMI 1640 (Gibco-BRL) media containing $20 \%$ pooled human serum, $10 \mathrm{mll} / \mathrm{liter}$ of a crude bovine brain extract, and 200 $1 \mathrm{U} / \mathrm{ml}$ of heparin sodium salt. Coating of the slides to which the cells were attached was performed by application of $200 \mu 10.1 \%$ gelatin in demineralized water (Mill Q) to each dry, sterile slide for 30 min at room temperature (RT). After removal of excess gelatin, every slide was incubated with $200 \mu \mathrm{l} 2.5 \%$ glutaraldehyde in Milli $Q$ for $15 \mathrm{~min}$ at $R T$, rinsed four times with phosphate-buffered saline (PBS: $0.15 \mathrm{M} \mathrm{NaCl}, 10 \mathrm{mM}$ sodium phosphate, $\mathrm{pH7.2)}$, and finally coated with $200 \mu / 150 \mu \mathrm{g} / \mathrm{ml}$ fibronectin in Hanks buffered saline solution (Gibco-BRL) for $30 \mathrm{~min}$ at $37^{\circ} \mathrm{C}$. HUVE cells were fixed by dipping in cold methanol $\left(-20^{\circ} \mathrm{C}\right)$ for $5 \mathrm{sec}$ and acetone $\left(4^{\circ} \mathrm{C}\right)$ three times for $5 \mathrm{sec}$, and were stored at $20^{\circ} \mathrm{C}$ until use.

\section{Preparation of metaphase spreads}

Chromosomes were prepared from peripheral blood using phytohemagglutinin stimulation, hypotonic spreading, and fixation in methanol:acetic acid $(3: 1 \mathrm{w} / \mathrm{v})$. Pretreatment of the metaphase spreads with RNase A and pepsin, followed by postfixation in $1 \%$ formaldehyde in PBS, has been described previously ${ }^{[19.34,44 !}$.

\section{DNA probes and labeling procedures}

The probes for the (peri)centromeric regions of the human chromosomes 1 ( $p U C$ 1.77), 7 $(\mathrm{p} 7 \mathrm{t1})$, and 17 ( $\mathrm{p} 17 \mathrm{H} 8$ ) have been described by Cooke and Hindley ${ }^{[17}$, Waye et al. ${ }^{[41]}$, and Waye and Willard ${ }^{[42]}$, respectively. The human $1 \mathrm{p}$-specific subtelomeric probe $\mathrm{p} 1-79$ was described by Buroker et al. ${ }^{|5|}$. The DNA probes were labeled with biotin-11-dUTP (Enzo Diagnostics, New York, NY, USA), digoxigenin-11-dUTP, or fluorescein-12-dUTP (Boehringer, Mannheim, Germany) in a standard nick-translation reaction and used in single-, double-, or triple-target ISH procedures.

\section{In situ hybridization procedure}

The DNA probes describes above were used at a concentration of $0.4 \mathrm{ng} / \mu \mathrm{l}$ ( $\mathrm{pUC} 1.77$ ) or $1 \mathrm{ng} / \mu / \mathrm{p} 7 \mathrm{t1}, \mathrm{p} 17 \mathrm{H} 8, \mathrm{p} 1-79)$ and hybridized in different combinations in a hybridization buffer containing $60 \%$ formamide, $2 \times S S C(0.3 \mathrm{M} \mathrm{NaCl}, 30 \mathrm{mM} \mathrm{Na}$-citrate), $\mathrm{pH} 5.0,10 \%$ dextran sulphate, $0.2 \mu \mathrm{g} / \mu \mathrm{l}$ yeast tRNA as carrier RNA. Ten $\mu$ l buffer was added to each slide under a coverslip $(20 \times 20 \mathrm{~mm})$. Denaturation was performed on the bottom of a metal box in a water bath at $70^{\circ} \mathrm{C}$ for $3 \mathrm{~min}$ and hybridization was performed overnight at $37^{\circ} \mathrm{C}$. The slides were washed twice for 10 min at $42^{\circ} \mathrm{C}$ with $60 \%$ formamide, $2 \times S S C, p H 5.0$, containing $0.05 \%$ Tween 20 , followed by two 5 min washes with $2 \times S S C, p H 7.0$, at $42^{\circ} \mathrm{C}$ and a 5 min wash with $4 \times$ SSC, pH 7.0, containing $0.05 \%$ Tween 20 (Buffer A) at RT.

\section{Cytochemical detection procedures}

To reduce background staining in the cytochemical detection procedures, the slides were pre-incubated with $4 \times \mathrm{SSC}, \mathrm{pH} 7.0$, containing $5 \%$ non-fat dry milk (Buffer $\mathrm{B}$ ) for 10 min at $37^{\circ} \mathrm{C}$, followed by dipping in Buffer $\mathrm{A}$ (see above). For all the detection procedures, the avidin conjugates were diluted in Buffer $B$, and all the antibody conjugates were dilluted in PBS containing $0.05 \%$ Tween 20 (Buffer $\mathrm{C}$ ) and $2 \%$ normal goat serum (NGS). After each incubation step of $20-30$ min at $37^{\circ} \mathrm{C}$, the slides were rinsed twice in Buffer $\mathrm{A}$ (avidin conjugates) or Buffer $\mathrm{C}$ (antibody conjugates). 


\section{Single-target ISH}

\section{Green PO-TMB detection}

For single-target ISH, the biotinylated pUC 1.77 probe was detected by incubating the slides with a 1:50 dilution of PO-conjugated avidin (AvPO; DAKO, Glostrup, Denmark). followed by the PO-TMB reaction protocol (see below). The cells were counterstained with hematoxylin, dehydrated, and mounted in Entellan (Merck, Darmstadt, Geimany).

\section{Double-target ISH}

\section{Brown PO-DAB and red APase-Fast Red detection}

First the biotinylated pUC1.77 probe was detected with one incubation layer of AVPO, followed by the PO-DAB reaction (see below). When the second probe was digoxigeninlabeled ( $p 7 t 1$ ), the slides were incubated with monoclonal mouse anti-digoxin (MaDig. 1:2000; Sigma, St Louis, MO, USA). If a fluoresceinated probe was used ( $p 17 \mathrm{H8}$ or $\mathrm{p} 1$ 79), detection was performed with monoclonal mouse anti-fluorescein (MaFITC, 1:500; DAKO). The monoclonal antibodies (MAbs) were detected with APase-conjugated goat anti-mouse IgG (GaMAPase, 1:25; DAKO), followed by the APase-Fast Red reaction (see below). The cells were counterstained with hematoxylin, washed in Milli $\mathrm{Q}$, air-dried, and mounted in PBS/glycerol (1:9).

\section{Brown PO-DAB and green PO-TMB detection}

After detection of the biotinylated pUC1.77 probe with PO-DAB as described above, the second probe was visualized by incubation with the appropriate MAb and a second layer of PO-conjugated rabbit anti-mouse IgG (RaMPO, 1:80; DAKO), fallowed by the PO-TMB reaction (see below). PO activity still present after the PO-DAB reaction was inactivated by incubation of the slides in $0.01 \mathrm{~N} \mathrm{HCl}$ for $10 \mathrm{~min}$ at $\mathrm{RT}$. The cells were counterstained with hematoxylin or ethyl green, dehydrated, and mounted in Entellan.

\section{Triple-target ISH}

Brown PO-DAB, red APase-Fast Red, and green PO-TMB detection

The general protocol for the triple-color in situ detection of three hybridized DNA probes that are modified with biotin, digoxigenin, and fluorescein is shown below. The total time, including wash steps is approximately 3 hrs.

\begin{tabular}{|c|c|c|c|}
\hline 1. & AwPO (1:50) & $20 \mathrm{~min}$ & $37 \% \mathrm{C}$ \\
\hline 2. & Detection of $\mathrm{PO}$ activity in brown (PO-DAB) & $5 \mathrm{~min}$ & $37^{\circ} \mathrm{C}$ \\
\hline 3 & $0.01 \mathrm{~N} \mathrm{HCl}$ (inactivation AvPO rest activity) & $10 \mathrm{~min}$ & PT \\
\hline 4. & MaDig/RaFITC (both $1: 2000$ ) & $30 \mathrm{mmn}$ & $37^{\circ} \mathrm{C}$ \\
\hline 5. & GaMAPase/SwaRPO $(1: 251: 100)$ & $30 \mathrm{~min}$ & $37^{\mathrm{5}} \mathrm{C}$ \\
\hline 6. & Detection of APase activity in red (APase-Fast Red) & $5-10 \mathrm{~mm}$ & $37^{\circ} \mathrm{C}$ \\
\hline 7. & Delection of $\mathrm{PO}$ activity in green (PO-TMB) & $1.2 \mathrm{~min}$ & $37^{\circ} \mathrm{C}$ \\
\hline 8. & Counterstaining with hematoxylim & 1. 500 & $\mathrm{Ar}$ \\
\hline g. & Alrmarying & romin & RT \\
\hline 10. & Embedding in a protein mallix & $10 \mathrm{~min}$ & $37^{\circ} \mathrm{C}$ \\
\hline
\end{tabular}

In Figure $1 \mathrm{c}$, a combination of biotinylated pUC 1.77, digoxigenin-labeled $\mathrm{p} 17 \mathrm{H8}$, and fluoresceinated $\mathrm{p} 7 \mathrm{t} 1$ was used, whereas in Figures $1 \mathrm{~d}-1 \mathrm{~g}$ and $1 \mathrm{k}$ biotinylated pUC1.77 was combined with digoxigenin-labeled $\mathrm{p} 7 \mathrm{t1}$ and fluoresceinated $\mathrm{p} 17 \mathrm{H} 8$. The cells were counterstained with hematoxylin, washed in Milli Q, air-dried, and embedded in a protein matrix as described previously ${ }^{\text {[3a! }}$. Briefly, the slides were smeared with $50 \mu$ l of a mixture 
of $20 \mathrm{mg} / \mathrm{ml}$ bowine serum albumin (BSA; Sigma) in Milli $\mathrm{Q}$ and $2 \%$ formaldehyde, and airdried. Then, the slides could be analyzed directly or mounted optionally in an aqueous or organic mounting medium, or in immersion oil, with similar results.

\section{Combined immunocytochemistry and in situ hybridization}

The procedure used for combined ICC and ISH was performed as described previously I32. In short, HUVE cells were blocked with Buffer C containing $2 \%$ NGS for 10 min, followed by an incubation for 45 min at RT with undiluted culture supernatant of MAb RV202, directed against the intermediate filament protein vimentin [28]. As a control, MAb RCK 102 was used, which was directed against human cytokeratin filaments 5 and 8 [28]. After washing three times for 3 min in Buffer $C$, the mouse antibodies were detected by incubation with B-Gal-conjugated goat anti-mouse IgG (GaMB-Gal, 1:25; SBA, Birmingham, AL, USA) for 45 min at RT. The cells were washed three times for 3 min in PBS, followed by the B-Gal-BCIG staining reaction (see below). Thereafter, the cells were washed in $0.01 \mathrm{~N}$ $\mathrm{HCl}$ tor 2 min at $37^{\circ} \mathrm{C}$, digested with $100 \mu \mathrm{g} / \mathrm{ml}$ pepsin in $0.01 \mathrm{~N} \mathrm{HCl}$ for 20 min at $37^{\circ} \mathrm{C}$, washed again in $0.01 \mathrm{~N} \mathrm{HCl}$ for $2 \mathrm{~min}$, dehydrated, and post-fixed with $1 \%$ paraformaldehyde in PBS for 20 min at $4{ }^{\circ} \mathrm{C}$. Cells were subjected to the ISH procedure as described above and were not counterstained in these cases. ISH on HUVE cells was performed as described above, omitting the steps for $I C C$.

\section{Detection of enzyme activity}

\section{APase-FAST RED reaction}

APase detection was performed as described previously ${ }^{[34]}$. In brief, 1 mg naphthol-ASMXphosphate (Sigma) in $250 \mu \mathrm{l} 0.2 \mathrm{M} \mathrm{Tris-HCl}$ buffer, $\mathrm{pH} 8.5$, containing $10 \mathrm{mM} \mathrm{MgCl} 2$ and 5 mg Fast Red TR salt (Sigma) in $750 \mu$ l buffer, were subsequently added to $4 \mathrm{ml}$ buffer with $5 \%$ polyvinyl alcohol (PVA, Mw 40000; Sigma). This solution was gently mixed, after which each slide was incubated with $100 \mu$ l of this reaction mixture under a coverslip for 5-10 min at RT. The slides were washed three times for 5 min with PBS.

\section{B-Gal-BCIG reaction}

B-Gal detection with 5-bromo-4-chloro-3-indolyl-B-D-galactoside (BCIG; Life Technologies, Breda, The Netherlands) was performed as described by Bondi et al. (ial. In brief, $2.5 \mu \mathrm{l}$ of a stock solution of $20 \mathrm{mg} / \mathrm{ml} \mathrm{BClGin} \mathrm{N}$, $N$-dimethylformamide was added to $100 \mu \mathrm{l}$ PBS containing $0.9 \mathrm{mM} \mathrm{MgCl2}, 3 \mathrm{mM}$ potassium ferricyanide, and $3 \mathrm{mM}$ potassium ferrocyanide. Each preparation was incubated with this reaction mixture under a coverslip for 20 $60 \mathrm{~min}$ at $37^{\circ} \mathrm{C}$ and washed three times for $5 \mathrm{~min}$ in PBS.

\section{PO-DAB reaction}

$\mathrm{PO}$ detection with $\mathrm{H} 2 \mathrm{O} 2$ and diaminobenzidine (DAB; Sigma) was performed as described by Graham and Karnovsky ${ }^{[10]}$, using $0.1 \mathrm{M}$ imidazole (Merck) in the reaction mixture. After each PO-DAB reaction of $5 \mathrm{~min}$, the cells were rinsed twice for $5 \mathrm{~min}$ in PBS.

\section{PO-TMB reaction}

PO detection with $\mathrm{H} 2 \mathrm{O} 2$ and 3,3 ',5, $5^{\text {- }}$-tetramethylbenzidine (TMB; Sigma) was performed

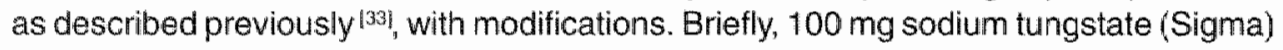
was dissolved in $7.5 \mathrm{ml} 100 \mathrm{mM}$ citrate-phosphate buffer, $\mathrm{pH} 5.1$, after which the $\mathrm{pH}$ was brought back to $\mathrm{pH} 5.0-5.5$ with $37 \% \mathrm{HCl}$. Just before use, $20 \mathrm{mg}$ dioctyl sodium sulfosuccinate (DSSS; Sigma) and $6 \mathrm{mg}$ TMB were dissolved in $2.5 \mathrm{ml} 1004$ ethanol at $80^{\circ} \mathrm{C}$ and added to the buffer together with $10 \mu \mathrm{l} 30 \% \mathrm{H} 2 \mathrm{O} 2$. The preparations were 
incubated with $100 \mu$ of this reaction mixture under a coverslip for $1-2 \mathrm{~min}$ at RT and washed three times for 1 min with $0.1 \mathrm{M}$ phosphate buffer, $\mathrm{pH} 6.0$, and $1 /$ min with Milli $\mathrm{Q}$.

\section{Brightfield microscopy}

Microphotographs were made on a Zeiss Axiophot microscope, using a Kodak Color Gold 100 ASA film in combination with blue and magenta filters.

\section{Results}

To develop a triple-target ISH detection procedure for brightfield microscopy, different combinations of two precipitating PO reactions (PO-DAB and PO-TMB) and one APase reaction (APase-Fast Red) were tested in several cell systems, including interphase preparations of T24 tumor cells or diploid HUVE cells and metaphase spreads of normal human peripheral lymphocytes (Table 1). The individual enzyme reactions have been described previousily and are routinely applied to ISH. The PO-TMB reaction, however, first needed some adaptation owing to the poor stability of its reaction product.

Table 1. Sequence of enzymatic detection systems (1-HII) in multiple-target ISH based on two $\mathrm{PO}$ and one Apase detection systems ${ }^{\text {a.b. }}$

\begin{tabular}{|c|c|c|c|c|c|}
\hline \multirow[t]{2}{*}{$\mathrm{ISH}$} & \multirow[t]{2}{*}{ Detection system } & $\mathrm{PO}$ & Apase & PO & \multirow[t]{2}{*}{ Enbedding } \\
\hline & & $\begin{array}{c}\text { DAB } \\
\text { (brown) }\end{array}$ & $\begin{array}{c}\text { Fast Red } \\
\text { (red) }\end{array}$ & $\begin{array}{c}\text { TMB } \\
\text { (green) }\end{array}$ & \\
\hline \multirow[t]{3}{*}{ Single-target } & 1 & 1 & & & Aqueous/organic \\
\hline & 2 & & 1 & & Aqueous \\
\hline & 3 & & & 1 & Organic \\
\hline \multirow[t]{3}{*}{ Double-target } & $4^{\circ}$ & 1 & $\|$ & & Aqueous \\
\hline & $5^{\mathrm{d}, \mathrm{s}}$ & 1 & & lil & Organic \\
\hline & $6^{0}$ & & 1 & $\|$ & Protein matrix \\
\hline Triple-target & $7^{\text {t.. } 98}$ & 1. & ll & Ili! & Protein matrix \\
\hline
\end{tabular}

a The enzyme reactions were performed directly after the incubation with the appropriate enzyme conjugate. The incubations used are described in Materials \& Mathods. For each ISH detection system the appropriate embedding medium is stated.

- Apase, alkaline phosphatase; DAB, diaminobenzidine; $15 H$, in situ hybridization; PO, horseradish peroxidase; $T M B$, tetramethylbenzidine.

- In enzyme activity detection after application of both enzyme conjugates, the reactions must be performed in the reversed order to prevent inactivation of Apase by the PO reaction.

"Inactivation of the $\mathrm{PO}$ activity after the first $\mathrm{PO}$ reaction with $0.01 \mathrm{~N} \mathrm{HCl}$ is essential.

-The $\mathrm{PO}-\mathrm{TMB}$ reaction must always be performed last, since the resulting precipltate proved to be unstable in aqueous solutions with a pH above pH 6 (e.g. MilliO and PBS).

'Embedding in a protein matrix is essential to prevent dissolving of the reaction products in an aqueous or organic mounting medium, or in immersion oil.

Modification of the PO-TMB reaction for $1 S H$

The PO-TMB reaction, described previously by us for use in $\| S H \mid{ }^{[33]}$, was modified by the addition of $10 \mathrm{mg} / \mathrm{ml}$ sodium tungstate to the reaction mixture to stabilize the resulting green precipitate. T24 cells, hybridized with the biotinylated DNA probe specific for the (sub)centromeric region of chromosome 1 and stained with AVPO, showed three specific green ISH signals in brightfield microscopy (Figure la). A staining reaction of 1-2 min appeared to be optimal for distinct localization of the $\mathrm{PO}-\mathrm{TMB}$ reaction product. The pre- 
cipitate proved to be stable during the washing steps in phosphate buffer and Mili $Q$, as well as during the dehydration steps. The cells could be counterstained with hematoxylin, embedded in organic mounting medium, such as Entellan or mineral oil, and stored permanenty at ${ }^{\circ} \mathrm{C}$. The $\mathrm{PO}$.TMB reaction product was unstable in aqueous mounting media, such as PBS/glycerol (1:9) and Imsol (Kinipath, Zevenaar, The Netherlands), in which it dissolves rapidly. The high sensitivity of the $\mathrm{PO}$-TMB reaction was demonstrated by the detectability of the telomere 1 -Specific DNA probe in T24 cells, using the same reaction time that was needed for the detection of the centromere probe (Figure 1b).

\section{Double-target $15 H$ detection procedures}

Brown PO-DAB and red APase-Fast Red detection

The biotinylated and the digoxigenin-labeled DNA probes, specific for the (sub)centromeric regions of chromosomes 1 and 7 , respectively, were hybridized simultaneously to 124 and HUVE cells, and enzyme cytochemically detected by the PO-DAB and APase-Fast Red reaction as outlined in Table 1 (detection system 4 ). The contrasting colors of the brown PO-DAB and the red APase-Fast Red precipitates could be clearly distinguished in T24 cells, showing three $1 \mathrm{SH}$ signals for both the centromeres of chromosomes 1 and 7 (shown in part in Figures 1d and 1e), as well as in HUVE cells, showing two ISH signals for both chromosomes (such as in Figure 1j). Cells were counterstained with hematoxylin and had to be embedded in aqueous mounting medium, since the APase-Fast Red reaction product is unstable in ethanol and organic-based mounting media (Table 1). The same results were obtained when both enzyme reactions (PO-DAB and APase-Fast Red) were performed after incubation of both enzyme conjugates. However, in that case the APase-Fast Red reaction was always performed before the PO-DAB reaction, since a reversed order decreased the APase activity significantly 17 !

\section{Brown PO-DAB and green PO-TMB detection}

A combination of the PO-DAB and $P O-T M B$ reaction could also be utilized for the visualization of two separately hybridized DNA probes in situ (Table 1, detection system 5). Figure ib shows the three brown (PO-DAB) ISH signals for the centromere of chromosome 1, together with four green (PO-TMB) signals for the telomere of this chromosome in T24 cells. Furthermore, the centromeric regions of chromosomes 1 and 7 were visualized with this double PO detection system in diploid HUVE cells (Figure 1i). The cells were counterstained with hematoxylin or ethyl green without losing color contrast and were embedded in organic mounting medium, since the PO-TMB reaction product is unstable in aqueous embeding media (Table 1). Inactivation of $\mathrm{PO}$ activity after the $\mathrm{PO}-\mathrm{DAB}$ reacthon was necessary before performance of the final $P O-T M B$ reaction, since omission of this inactivation step leads to mixing of the precipitates on the first detected DNA target (data not shown). Therefore, the slides were incubated with $0.01 \mathrm{~N} \mathrm{HCl}$ for 10 min at RT immediately after the PO-DAB reaction or after application of the second incubation layer. This procedure, which was described earlier by Nibbering et al. "25n, appeared to affect neither the final ISH results nor cell morphology.

\section{Tiple-target ISH detecion procedure}

The PO-DAB, APase Fast Red, and PO-TMB reactions were combined in a triple-staining procedure lor simultaneous visualization of three centromere-specific DNA probes in different cell preparations. (Table 1, detection system 7). Figure 1c shows the centromeric regions of chromosomes 1,7 , and 17 in the contrasting colors brown (PO-DAB), green (PO-TMB), and red (APase-Fast Red), respectively, in T24 cells that are not counterstained. 
Evidently, T24 cells contain three copies of the centromeres of chromosomes 1 and 7 and four copies of the centromere of chromosome 17. The same chromosomal regions are accurately discernible in brown, red, and green, respectively, in either T24 cells (Figures $1 \mathrm{~d}$ and $1 \mathrm{e}$ ) or human metaphase spreads (Figures $1 /$ and $1 \mathrm{~g}$ ) after counterstaining with hematoxylin. The copy numbers of the centromeric regions of chromosomes 1,7 , and 17 were in agreement with those in Figure 10, whereas a disomy for these chromosomal regions was seen in the diploid metaphase spreads and lymphocyte nuclei (Figures iff and $1 \mathrm{~g}$ ). The entire detection procedure, which can be performed within 3 hrs, is outlined in 'Materials and Methods'. As already described for the double-target ISH, mild acid treatment was essential for inactivation of the first applied PO activity, whereas the PO$T M B$ reaction was always performed at the end of the detection procedure to ensure the stability of the reaction product (Table 1). Since the APase-Fast Red precipitate is unstable in ethanol and organic mounting media and the PO-TMB reaction product dissolves in aqueous mounting media, the cells were always air-dried after courterstaining and

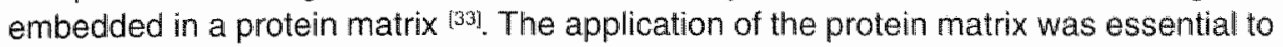
obtain a clear color contrast between the different enzyme precipitates. Moreover, this protein layer stabilizes the precipitates permanently and prevents them from being dissolved in any of the applied mounting media. Similarly, combination of the APase-Fast Red and PO-TMB detection systems for double-target ISH, as outlined in Table 1 (detection system 6), also requires application of a protein matrix to obtain permanent preparations.

\section{Combined ICC and multiple-target ISH}

Since in the ISH procedure antigenic epitopes are likely to be destroyed, ICC was always applied before the ISH procedure. As a model system we used HUVE cells, which express the intermediate filament protein vimentin but do not contain cylokeratins. Application of the mouse anti-vimentin MAb could be visualized by the B-Gal-BCIG reaction, resulting in a specific blue vimentin staining pattern with reasonable fibrillar localization (see, e.g., Figures $1 \mathrm{~h}, 1 \mathrm{j}$, and $1 \mathrm{k}$ ). In contrast, no staining was observed when the mouse anticytokeratin MAb was used (data not shown). The B-Gal-BClG reaction product appeared to be unaffected by the ISH procedure, as reported by others ${ }^{[29.37]}$. Therefore, the B-GalBCIG ICC could be combined with the absorption ISH methods described above. This is demonstrated, for example, in Figure $1 \mathrm{~h}$, in which vimentin was visualized simultaneously with both the centromeres of chromosomes 1 and 7 in diploid HUVE cells (ISH with double PO detection). To demonstrate the specificity of the ISH signals, the HUVE cells were also subjected to double-target ISH without prior ICC staining for vimentin (Figure 1i). All nuclei contained two copies for the centromeres of chromosomes 1 and 7 , as also observed in Figure 1h. A better color contrast could be obtained, if the B-Gal-BClG used for the visualization of vimentin was combined with double-target $\| S H$ using the PO-DAB (brown) and APase-Fast Red (red) detection systems (Figure 1j). Finally, the triple-color ISH method was combined with $I C C$, resulting in the simultaneous localization of the centromeres of chromosomes 1 (brown), 7 (red), and 17 (green), together with vimentin (blue) in the cytoplasm of diploid HUVE cells (Figure $1 \mathrm{k}$ ).

\section{Discussion}

We report here the development of a new and rapid triple-color ISH detection procedure for the simultaneous detection of three chromosome-specific. DNA sequences by brightfield microscopy in interphase nuclei and metaphase preparations. A combination of three 


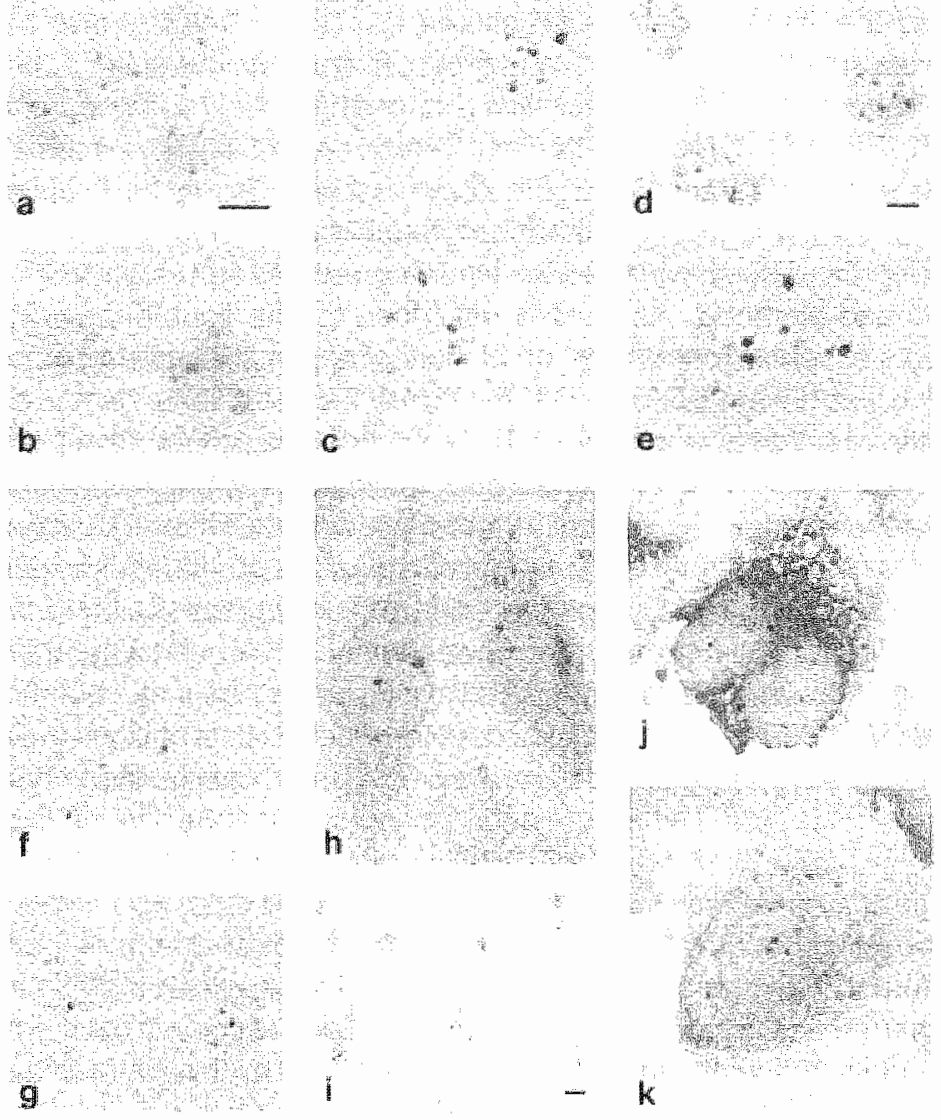

Figure 1. Brightfield detection of (a) single-target, $(\mathrm{b}, \mathrm{h}-\mathrm{j})$ double-target, and $(\mathbf{c}-\mathbf{g}, \mathbf{k})$ triple-target ISH in T24 cells (a-e), human lymphocyte metaphase spreads $(t-g)$, and HUVE cells $(h-k)$. Some of these cell preparations were immunocytochemically stained for vimentin belore the USH procedure $(h, j, k)$. Nuclei were counterstained with haematoxylin $(a, b, d-g)$ or ethyl green (i). DNA. probes used were: pUC 1.77 biotin (a) in combination with either $p 1.79$ fluorescein (b) or p7t1 digoxygenin (h-1), pUC 1.77 biotin in combination with either $p 7 t 1$ thorescein or 17148 digoxygenin (c) or $\mathrm{p} 7 \mathrm{t} 1$ digoxygenin and $\mathrm{p} 17 \mathrm{H} / \mathrm{B}$ fluorescein (d-g,h). (a) Detection of the (sub)centromeric regions of chromosome 1 in green ( $P O-T M B$ ). (b) Detection of the (sub)centromeric and (sub)telomeric regions of chromosome 1 in brown (PO-DAB) and green (PO-TMB), respectively. (c) Detection of the (sub) centromeric regions of chromosomes 1,7 , and 17 in brown (PO-DAB), green (PO-TMB), and red (APase*Fast Red), respectively. $(\mathrm{d}-\mathrm{g}$ ) Detection of the (sub)centromeric regions of chromosomes 11,7 , and 17 in brown (PO-DAB), red (APase-Fast Red), and green (PO-TMB), respectively. (h) Simultaneous detection of the intermediate fillament protein vimentin in blue (B-Gal-BClG) and the (sub)centromeric regilons of chromosomes 11 and 7 in brown (PO-DAB) and greem (PO-TMB). (1) Similar detection of the chromosomal regions as seen in $\mathrm{h}$ without ICC staining. (1) Similar ICC-ISH staining as seen in $h$, except for the (sub)centromeric region of chromosome 7. which is now shown in red (APase Fast Red). (k) Similar ICC.1SH staining as seen inj with the extra detection of the (sub) centromeric region of chromosome 17 in green (PO-TMB). Bars: 5 um. For color illustration see page 97. 
DNA probes, labeled with either biotin, digoxigenin, or fluorescein, could be hybridized simultaneously, since the cytochemical detection layers used are unrelated and do not interfere with each other. Distinct localization of the DNA probes was accomplished within 3 hrs by consecutive application of three sensitive enzyme cytochemical reactions, i.e., PO-DAB, APase-Fast Red, and PO-TMB (Table 1). Since the optimal conditions for each of these reactions were different, they had to be performed in succession. The reactions resulted in clearly contrasting and discernible brown, red, and green precipitates, respectively.

The present results have demonstrated that the PO-TMB reaction product can be efficiently stabilized with the addition of sodium tungstate to the reaction mixture, resulting in discretely localized green ISH signals. The reaction is extremely fast and sensitive, since incubation for 1-2 min proved to be sufficient far localization of both centromere- and telomere-specific DNA probes. Therefore, this reaction can be considered as an interesting alternative to the frequently used $\mathrm{PO}-\mathrm{DAB}$ reaction in terms of reaction velocity and sensitivity. Because the p1-79 probe for the (sub)telomeric region of chromosome 1 hybridizes with a repetitive target DNA sequence of only some $100 \mathrm{~kb}$ [5], the brightfield detection of yeast artificial chromosomes (YACs) and, eventually, cosimid probes with the PO-TMB reaction may now be within reach. We are now investigating the feasibility of applying this detection procedure in combination with brightfield microscopy.

The introduction of the PO-TMB reaction has considerably improved the multiplicity of color combinations for ISH. The PO-TMB reaction can be combined efficiently with both PO-DAB and the APase-Fast Red reaction, resulting in an extension of detection meth ods to double-target ISH as well as to the development of the triple-target ISH method for brightfield microscopy. However, the utilization of two PO and one APase detection procedures in one protocol requires some specific adaptations. First, the activity of the firstly applied PO conjugate may pose a serious problem in the second $\mathrm{PO}$ reaction. Therefore, the enzyme activity of the first detection round must be irreversibly inactivated. This could be achieved by a brief $0.01 \mathrm{~N} \mathrm{HCl}$ treatment of the cell preparations, which has been recommended by Nibbering et al, ${ }^{[25]}$ as an alternative to $\mathrm{H}_{2} \mathrm{O} 2$ 2. This treatment appeared to have no apparent negative effect on the detection of the digoxigenin-and fluoresceinlabeled probes or on cell morphology. Furthermore, the PO-DAB precipitate remained stable during the mild acid treatment, which has also been proven to be advantageous in combined ICC and ISH procedures ${ }^{[21]}$.

Second, the triple-color ISH detection procedure requires embedding of the cell preparations in a thin protein layer, which appeared to be essential to obtain an optimal color contrast of the enzyme precipitattes used. We have applied this approach previously for use in sensitive and multicolor reflection contrast microscopy ${ }^{[33 !}$. Since the PO-TMB reaction product is unstable in aqueous mounting media and the APase-Fast Red reaction product is unstable in an organic mounting medium, the embedding of the combination of both reaction products in a protein layer proved to be extremely useful, particularly since air-drying of the slides alone has been diemonstrated to yield only poor color contrast of the enzyme precipitates. Moreover, the cell preparations could be permanently stabilized in this manner. In comparison with the multicolor rainbow detection system generally used for blot hybridization and described by Hoeltke et al. ${ }^{[14]}$, our ISH detection procedure can be performed within 3 hrs, which is only half of the time required for the rainbow system. Furthermore, we use enzyme reactions that are specifically optimized for discrete localization of DNA sequences in situ. Moreover, the PO inactivation step with $0.01 \mathrm{~N} \mathrm{HCl}$ has no serious effect on cell morphology, whereas the repeated APase inactivation at $85^{\circ} \mathrm{C}$ performed in the rainbow system most probably is fatal for the preservation of cell mor- 
phology. Our new triple-color detection procedure for nucleic acid sequences in situ may, therefore, also be advantageous for use on blots with respect to time and localization properties.

A further extension of colors for blot and in situ hybridization could be explored by utilizing colored precipitates that are generated by other PO chromophores, such as aminoethyl carbazole (AEC) [1!] and chloronaphthol [a], or by other APase reactions using nitroblue tetrazolium (NBT) and 5-bromo-4-chloro-3-indolyl-phosphate (BCIP). In addition, combined $P O$ and APase reactions can be applied, resulting in mixed colors as described for ICC by Claassen et al. [6]. In this respect, the efficacy of the mild acid treatment step to inactivate $P O$ activity can be of help. However, the influence of the enzyme inactivation procedures on the stability of the precipitates and nucleic acid probe labels, as well as the order of enzyme detection, will ultimately determine the utility of these efforts for nucleic acid detection systems.

The described ISH detection procedure could also be combined with a specific ICC staining reaction of HUVE cells using the B-Gal-BCIG reaction. This enzymatic reaction, which could not be utilized for ISH, resulted in a blue indolyl precipitate that was reasonably well localized and stable on pepsin treatment at $\mathrm{pH} 2.0$, as well as throughout the entire ISH procedure. The ISH results on the immunostained diploid HUVE cells showed the expected two copies per nucleus for each centromere-specific DNA sequence tested, and when compared with non-immunostained cells. Therefore, the B-Gal-BCIG reaction product does not seem to make the cells less accessible to ISH reagents or to shield the target DNA. This finding is consistent with earlier reports ${ }^{[29,37]}$, and similar properties have been described for the APase-Fast Red reaction product if fluorescence analysis is preferred ${ }^{[32]}$. The PO-DAB precipitate, however, has been shown to often shield the target DNA ${ }^{[35.37]}$. Since the color contrast between the $B-G a l-B C I G$ and the $P O-T M B$ reaction product is relatively low, the combined $I C C$-ISH procedure with PO-DAB and APase-Fast Red is recommended. However, it is clear that the triple-color ISH detection procedure can also be efficiently combined with $B-G a l-B C I G I C C$, making this procedure extremely suitable for use in immunophenotyping cells that contain a specific chromosomal aberration or viral infection. Therefore, it may gain wide applicability in diagnostic pathology.

In the light of the developments in interphase cytogenetics, the presented tricolor ISH method can be of value for the detection of both numerical and structural chromosome aberrations in tumor cells ${ }^{15}, 26.35$. As shown in Figures 1c-1e, imbalances between the number of centromeric regions of specific chromosomes could be detected with high efficiency in T24 ceils. In addition, alimost all cells could be shown to contain four copies of a telomere 1-specific DNA sequence, whereas only three copies of the centromere 1-specific sequence could be detected (Figure 1b). This kind of chromosomal aberration can now be visualized easily with brightfield microscopy, bypassing the need for a fluorescence microscope. The application of the described triple-color ISH detection procedure for the study of tumor heterogeneity in tissue sections and cytological preparations, as well as chromosome aneuploidy in sperm cells, is now under investigation. Although the number of experiments as yet is limited, in all these cases the protocol could be used without any modification in the sequence of enzymatic reactions and reaction conditions.

\section{Acknowledgements}

We thank J Albrechts for the preparation of metaphase spreads, and A van Geelen (Department of Microbiology, Acadenic Hospital Maastricht) for culturing the HUVE cells. This work was supported by the Netherlands Organization for Scientific Research NWO, grant no. 900 . 


\section{References}

1. Bauman, J, Wiegant, J, Borst, P and Van Duin, P. A new method for fluonescence microscopical localization of specific DWA sequences by in situ hybridization of fluorochrome labeled PNA. Exp Cell Res 128: 485 (1980).

2. Böck, $G$. Hilchenbach, M, Schauenstein, $K$ and Wick $G$. Photometric analysis of antifading re. agents for immunofluorescence with laser and conventional illumination sources. I Histochem Cytochem 33: 699 (1985).

3. Bondi, A, Chieregatti, G, Eusebi, V, Fulchen, E and Bussolati, G. The use of B-galaclosidase as a tracer in immunocytochemistry. Histochemistry 76: 153 (1982).

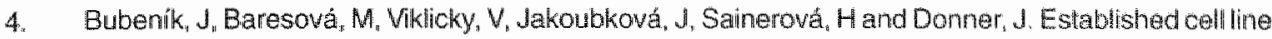
of urinary bladder carcinoma (T24) containing tumour specific antigen. In J Cancer 11: 765 (1973).

5. Buroker, $N$, Bestwick, $\mathrm{R}$, Haight, $\mathrm{G}$, Magenis, $\mathrm{A}$ and Litt, M. A hyperwariable repeated sequence on human chromosome 1p36. Hum Gener 77: 175 (1987).

6. Claassen, E, Boorsma, D, Kors, N and Van Rooijen, N. Double-enzyme conjugates, producing an intermediate color, for simultaneous and direct detection of three different intracellutar immunoglobu. fin determinants with only two enzymes. 1 Histochem Cytochem $34: 423(1986)$.

7. Cooke, Hand Hindley, J. Cloning of human satellite III DNA: different components are on different chromosomes. Nucleic Acid Res 6: 3177 (1979).

8. Emmerich, P, Loos, P, Jauch, A, Hopman, A, Wiegant, J. Higgins, M, White, B, Van der Ploeg, M, Cremer, $C$ and Cremer, T. Double in situ hybridization in combination with digital image analysis: a new approach to sludy interphase chromosome topography. Exp Cell Res 181: 126 (1989).

9. Gentilomi, $G$, Musiani, M, Zerbini, M, Gibellini, D, Gallinella, $G$ and Venturoli, $S$. Double in situ hybridization for detection of Herpes simplex virus and Cytomegalovirus DNA using non-radioactive probes J Histochem Cytochem 40:421 (1992).

10. Graham, Fi and Karnovisky, M. The early stages of absorption of injected horseradish peroxidase in the proximal tubules of mouse kidney: ultrastructural cytochemistry by a new technique.J Histochem Oytochem 14:291 (1966).

11. Giraham, R, Lundholm, U and Karnowsky, M. Gylochemical demonstration of peroxidase activity with 3-amino-9-ethylcarbazole. J Histochem Cytochem 13: 150 (1964).

12. Gu, $Y$, Chen, $Y$ and $Y e, L$. Electron microscopical demonstration of horseradish peroxidase by use of tetramethylbenzidine as chromogen and sodium tungstate as stabilizer (TMB-ST method): a tracing method with high sensitivity and well preserved ulltrastructural tissue. I Neurosci Methods 42: 1 (1992).

13. Herrington, C, Bums, J, Graham, A, Bhatt, B and McGee, J. Interphase cytogenetics using bioth and digoxygenin labelled probes $\| \mathrm{l}$ : simultaneous differential detection of human and papilloma virus nucleic acids in individual nuclei. 1 Clin Pathal $42: 601$ (1989).

14. Houltke, H, Ettl, I, Finken, M, West, $S$ and Kunz, W. Multiple nucteic acid labeling and rainbow detection. Anal Biochem 207: 24 (1992).

15. Hopman, A, Ramaekers, F, Raap, A, Beck, لd, Devilee, P, Van der Ploeg, M and Vocils, G. In situ hybridization as a tool to study numerical chromosome aberrations in solid bladder tumors. His. tochemistry 89 : 307 (1988).

36. Hopman, A, Speel, E, Voorter, $C$ and Pamaekers, F. DNA probe labelling methods. In. E. Levy and C. Herrington, eds. Non-isotopic techniques in molecular biology: a practical approach. Oxford: $\|$ FL Press, University Press: (1995).

17. Hopman, A. Wiegant, J, Raap, A, Landegent, J, Van der Ploeg, M and Van Duijn. P. Bi-color deteclion of two target DNAs by non-radiaactive in situ hybridization. Histochemistry 85: 1 (1986).

18. Kerstens, H. Paddighe, P and Manselaar, G. Double-target im situ hybridization in brightfield microscopy. Genet Anal Tech Appl 8: 24 (1994).

49. Lichter, P. Boyle, A, Cremer, T and Ward, D. Arralysis of genes and chromosomes by nonisotopic in situ hybridization. Genet Anal Tech Appl 8: 24 (1991).

20. Mullink, H. Walboomers, J, Raap. A and Meiler, C. Two colour DWA in situ hybridization for the detection of two viral genomes using non-radioactive probes. Histochemistry $91: 195$ (1989a).

21. Mullink, H, Waboomers, If Tadema, T, Jansen. D and Meijer, C. Combined immuno- and nonradioactive hybridocytochemistry on cells and tissue sections: influence of fixation, enzyme pretreatment, and choice of chromagen on detection of antigen and DNA sequences. J Histochem Cytochem 37: 603 (19896).

22. Nakane. P. Simultaneous localization of multiple tissiue antigens using the peroxidase-labeled antibody method: A study on pituitary glands of the rat. Histochem Cylochem 16.557 (1968).

23. Narayanswami, Sand Hamkal0.B. DNA sequence mapping using electron microscopy. Genet Anat Tech Appl 8: 14 (1991).

24. Nederlof, P, Robinson, D, Abuknesha, R, Wiegant, J, Hopman, A, Tanke. Hand Raap, A. Three-color futurescence in situ hybridization for the simultaneous detection of multiple nucleic acid sequences. 
Cylometry 10: 20 (1989).

25. Nibbering, P. Marinnen, J, Faap, A, Leih, P and Van Furth, $A$. Quantitative study of enzyme immunocytochemical reactions performed with enzyme conjugates immobilized on nitrocellulose. Histochemistry $84: 538(1986)$.

26. Poddighe, P, Ramaekers, F, Smeets, A, Vooljs, G and Hopman, A. Structural chromosome 1 aberrations in transitional cell carcinoma of the bladder; interphase cytogenetics combining a centromeric, telomeric, and library DNA probe. Cancer Res 52: 4929(1992)

27. Paap, A, Hopman, A and Van der Ploeg. M. Hapten labelng of nucleic acid probes for DNA in situ hybridization. In: G. Bullock and P. Petrusz, eds. Techniques in immunocytochemistry. Cambridge: University Press, Vol 4: 167. (1989).

28. Ramaekers, $F$, Huysmans, $A$, Schaan, $G$, Moesker, $O$ and Vocils, $P$. Tissue distribution of keratin 7 as monitored by a monoclonal antibody. Exp Cell Res 170:235 (1987).

29. Robben, $H$, Van Dekken, $H$, Poddighe, $P$ and Voofis, $G$. ldentification of aberrant cells in cytological specimens by combined in situ hybridization and immunocytochemistry. Cyropathology 5: 384 (1994).

30. Rudkin, $G$ and Stollar, B. High resolution detection of DNA-RNA hybrids in situ by indirect immunofluorescence. Nature 265: 472 (1977).

31. Seveus, L, Väisälä, M, Syrjänen, $S$, Sandberg, M, Kuusisto, A, Harju, R, Salo, J, Hemmilä, I, Kojola, H and Soini, E. Time-resolved fluorescence imaging of europium chelate label in immunohistochemistry and in situ hybridization. Cytometry $13 ; 329$ (1992).

32. Speel, E, Herbergs, J, Ramaekers, F and Hopman, A. Combined immunocytochemistry and thorescence in situ hybridization for simultaneous tricolor detection of cell cycle, genomic, and phenotypic parameters of tumor cells. J Histochem Cytochem 42: 961 (1994).

33. Speel, E, Kamps, M Bonnet, J, Ramaekers, $F$ and Hopman, A. Multicolour preparations for in situ thybridization using precipitating enzyme cytochemistry in combination with reflection contrast microscopy. Histochemistry 100: 357 (1993).

34. Speel, E, Schutte, B, Wiegant, J, Ramaekers, F and Hopman, A. A novel fluorescence detection method for in situ hybridization based on alkaline phosphatase-fast red reaction. J Histochem Cytochem 40: 1299 (1992).

35. Strehl, S and Ambros, P. Fluorescence in situ hybridization combined with immunohistochemistry for highly sensitive detection of chromasome 1 aberrations in neuroblastoma. Cytogenet Cell Genet 63: 24 (1993).

36. Trask, B. Fluorescence in situ hybridization: applications in cytogenetics and gene mapping. Trends Genet7: 149 (1991).

37. Van den Brink, W, Van der Loos, C, Volkers, H, Lauwen, $R$, Van den Berg, F, Houthoff, H-J and Das, P. Combined B-Galactosidase and immunogold/silver staining for immunohistochemistry and DNA in situ hybridization. J Histochem Cylochem 38: 325 (1990).

38. Van der Loos, C, Das, P and Houthoff, H-u. An immunoenzyme triple staining method using both polyclonal and monoclonal antibiodies from the same species. Application of combined direct, indirest and avidin-biotin complex (ABC) technique. J Histochem Cytochem 35: 1199 (1987).

39. Van dier Loos, C, Das, P, Van den Oord, J and Houthoff, H-J. Multiple immunoenzyme staining techniques. Use of fluoresceinated, biotinylated and umlabelled monoclonal antibodies. I /mmunol Methods 117: $45(1989)$.

40. Van der Loos, $C$, Van den Dord, J, Das, P and Houthoff, H-J. Use of commercially availlable mono. clonal antibodies for immunoenzyme double staining. Histochem J20: 409 (1988).

41. Waye, J, England, S and Willard, H. Genomic organization of alpha satellite DNA on human chromosome 7: evidence for wo distinct alphoid domains on a single chromosome. Mol Cell Biol 7: 349 (1987).

42. Waye, $J$ and Willard, H. Molecular analysis of a deletion polymorphism in alpha satellite of human chromosome 17: evidence for homologous unequal crosising-over and subsequent fixation. Nucleic Acids Fes 14: 6915(1986).

43. Weinberg, F and Van Eyck, S. A tetrahethylbenzidine/tungstate reaction for horseradish peroxidase histochemisiry. J Histochem Cytochem 39: 1143 (1991).

44. Wiegant, ل, Ried, T, Nederlof, P, Van der Ploeg, M, Tanke, H and Raap, A. In situ hybridization with fluoresceinated DNA. Nucleic Acids fies 19:3237 (1991). 


\section{Chapter 3}

\section{Comparison of A- and B-type lamin expression in nodular sclerosing Hodgkin's disease and reactive lymph nodes}

Maurice PHM Jansen, Barbie M Machiels, Anton HN Hopman, Jos LV Broers, Frederik J Bot, Jan Willem Arends, Frans CS Ramaekers, and Harry C Schouten 


\section{Abstract}

Lamins are a family of nuclear membrane-associated intermediate filament proteins, of which the A-type lamins are preferentially expressed in differentiated cells. The B-type lamins $B 1$ and $B 2$ have long been considered to be constitutively expressed, but only recently have we come across several examples of a differential expression of these two latter lamin subtypes, with lamin B1 being related to proliferation.

In order to clarify the differentiation and proliferation status of the Reed-Sternberg and Hodgkin cells we studied A- and B-type lamin expression with specific monoclonal antibodies in Hodgkin's disease. Its normal counterpart, the reactive lymph node, was also examined for lamin subtype expression.

The CD20 positive centrocytes and centroblasts of the follicle centre in the reactive lymph nodes expressed lamin B1, but were not or only very weakly positive for lamin B2 or A-type lamin antibodies. Mantle zone lymphocytes displayed lamins B1 and B2, but were negative for A-type lamins. Furthermore, CD3- and CD20-positive lymphocytes in the medulla and paracortex lacked A-type lamins, but were positive for both B-type lamins. Finally, the proliferation marker Ki-67 was mainly detected in the centroblasts, but also in a fraction of the A-type lamin negative cells in the paracortex and medulla.

In Hodgkin's disease, all cells expressed lamins B1 and B2, whereas a small subpopulation of cells had A-type lamins. CD30-positive Reed-Sternberg and Hodgkin cells were primarily positive for A-type lamins and about $20 \%$ of the Reed-Sternberg and Hodgkin cells expressed $\mathrm{Ki}-67$, with co-expression of lamin A in most of these cells.

All in all, Ki-67 and A-type lamin positivity in general were mutually exclusive in lymph nodes, indicating that A-type lamin positive cells are not proliferative. This also suggests that the A-type lamin expression in Reed-Sternberg and Hodgkin cells is correlated with a relatively mature phenotype of these malignant cells. However, part of these differentiated malignant cells still have a capacity to proliferate as indicated by Ki-67 positivity. Our observation that lamin $B 2$ expression in the follicle centre cells of the reactive lymph node is low or absent indicates that this lamin subtype is not always expressed in nucleated cells, which is in clear contrast to the results obtained in previous studies in other diseases and in normal tissues. Absence of lamin B2 expression may be associated with the follicle centre stage of B-cells.

\section{Introduction}

Lamins belong to the intermediate filament protein family and are constituents of the nuclear lamina. In vertebrates two types of lamins have been recognized, i.e. lamins of the neutral A-subtype and lamins of the acidic B-subtype ${ }^{[1,18.23] . ~ T h e s e ~ s u b t y p e s ~ d i f f e r ~ i n ~ t h e i r ~ p r i-~}$ mary sequences and $\mathrm{pl}$, and each subtype consists of several distinct phosphorylation isoforms ${ }^{|2.15|}$. The B-type lamins B1 and B2 (Mw 65-67 kDa) seem to be involved in the association of the nuclear lamina to the inner nuclear membrane, which may result in stabilisation of the nuclear envelope ${ }^{[26]}$. B-type lamins have long been thought to be constitutively expressed in all somatic nucleated cells of vertebrates ${ }^{[6,22]}$. During mitosis, the nuclear lamina desintegrates due to phosphorylation of the lamins, but B-type lamins remain associated with vesicles originating from the nuclear membrane ${ }^{[1]}$.

Expression of the A-type lamins, consisting of lamin A and lamin C, is largely restricted to differentiated cells and not extensively found in proliferating cells ${ }^{[6,23]}$. Recent results indicate that statin, an antigen associated with non-proliferative cells, is identical to A-type lamins ${ }^{[7]}$. Statin and the proliferation marker Ki-67 segregate to distinct populations in cytospins of lymphoid cell suspensions, confirming the anti-proliferative expresssion of 
statin or A-type lamins [30). A-type lamins have intrinsic chromatin-binding capacity, and as a result may be involved in a topological organization of chromatin and in the regulation of replication and transcription $[10-1224$. During mitosis the phosphorylated A-type lamins, in contrast to the B-type lamins, become soluble and disperse throughout the cytoplasm.

Human lymphocytes of the early differentiation stages, as well as the neoplastic cells in acute lymphoblastic leukemia (ALL) and non-Hodgkin's lymphomas (NHL), are known to

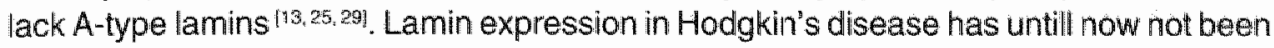
characterized. Next to lymphocytes, this latter tumor type contains macrophages and histiocytes, as well as the morphologically distinguishable Reed-Sternberg and Hodgkin cells. The multinucleated Reed-Sternberg cells and mononucleated Hodgkin cells are considered to represent the malignant fraction in Hodgkin's disease, although they amount to only $2-3 \%$ of the total cell population. So far, the origin and stage of differentiation of the Reed-Sternberg cells have not been completely elucidated 114, 19:. A recent study, however, suggests on basis of rearranged $V_{H}$ and $V_{L}$ genes that the malignant cells in Hodgkin's disease originate from germinal center $\mathrm{B}$-cells ${ }^{[20]}$.

The aim of this study was to analyse lamin expression in cells of Hodgkin's disease in relation to their proliferative capacity and to compare these reaction patterns to those found in reactive lymph nodes, in an attempt to clarify the degree of differentiation of the malignant cells in Hodgkin's disease.

\section{Materials \& Methods}

\section{Tissue specimens}

Frozen biopsy specimens of nine patients with Hodgkin's disease nodular sclerosis subtype were investigated. In addition, twelve frozen biopsy specimens of reactive lymph nodes were analysed.

\section{Antibodies}

The following mouse monoclonal antibodies against A-and B-type lamins were used in this study for immunocytochemical analyses:

1. $133 \mathrm{~A} 2$ (lgG3) against lamin $A^{[16]}$, kindly provided by Dr. Y. Raymond (Montreal/Canada), mouse ascites diluted 1:1000;

2. $41 \mathrm{CC} 4$ (IgM) against lamin $\mathrm{A} / \mathrm{C}^{[3]}$, kindly provided by Dr. G. Warren (London/United Kingdom), culture supernatant used undiluted;

3. R27 (IgM) against lamins A/C ${ }^{[32]}$, kindly provided by Dr. G. Krohne (Würzburg/Germany), culture supernatant used undiluted;

4. X223 (IgG1) against lamin B2 ${ }^{15}$, kindly provided by Dr. G. Krohne, ascites diluted $1: 100^{*}$ 5. 101B7.2 (IgG1) against lamin B2 (Matritech Inc., Cambridge, MA), ascites diluted 1:100; 6. LN43 (lgG1) against lamin B2 ${ }^{\text {III }}$ kindly provided by Dr. E.B. Lane (Dundee/UK), culture supernatant used undiluted;

7. 119D5 (lgG1) against lamin B1, kindly provided by Dr. Y. Raymond, ascites diluted 1:750. The leucocyte common antigen antibody (LCA), diluted 1:200 was used as a positive control. Phosphate buffered saline (PBS) pH 7.0 without primary antibodies was used as a negative control. The secondary antibody for the immunocytochemical detection of antibody binding was a peroxidase conjugated rabbit anti mouse immunoglobulin (DAKO AVS, Glostrup, Denmark), diluted 1:100.

Primary antibodies recognizing lymphocyte subtypes and used for the double label immulnofluorescence studies, are:

1. anti-CD3, a rabbit polyclonal antiserum recognizing T-lymphocytes (DAKO), diluted 1:100; 
2. Anti-CD20, a mouse monoclonal IgG2a binding B-lymphocytes (L26; DAKO), diluted 1:1000;

3. Anti-CD30 (Ber-H2 clone; DAKO), a mouse monoclonal IgGi detecting Reed-Sternberg cells, Hodgkin cells and activated lymphocytes [26), diluted 1:25.

Finally, a rabbit polyclonal antiserum recognizing the prolfferation marker Ki-67 (DAKO) was used in combination with lamin antibodies and/or anti-CD30. The secondary antibodles used in the double-label immunofluorescence analyses were: fluorescein isothiocyanate (FITC) conjugated goal anti rabbil (Sigma, St. Louis, MO, USA), diluted 1:100, for the detection of anti-CD3; FITC labeled goat anti mouse IgG2a (Southern Biotechnology Associates, Inc., Birmingham, USA (SBA)), diluted 1:40, for the detection of anti-CD20; FITC labeled goat anti mouse IgG1 (SBA), dilluted 1:40, for the detection of anti-CD30; biotin labeled horse anti mouse (DAKO), diluted 1:200, with AMCA conjugated avidin (Vector, Brunschwig Chemie, Amsterdam, The Netherlands), diluted 1:100, for detection of CD30; Texas Red conjugated goat anti mouse IgM (SBA), diluted 1:40, for the detection of lamin AVC antibody R27. For signal enhancement FITC labeled antibodies were reincubated with rabbit anti FITC (DAKO), diluted 1:100 and FITC conjugated swine anti rabbit immunoglobulins (DAKO), diluted 1:100. Finally, Ki-67 antigen was detected with FITC conjugated swine anti rabbit antibody (DAKO).

\section{Immunoperoxidase staining procedure}

Five um thick sections were cut with a cryostat (Cryocut 1800, Reichert-Jung, Leica) from all frozen biopsy specimens, brought onto poly-L-lysine coated glass slides and fixed in acetone for five minutes at $4^{\circ} \mathrm{C}$. After fixation, slides were washed three times five minutes in PBS pH 7.5 at room temperature (RT). Slides were incubated with appropriately diluted mouse monoclonal antibodies for one hour at RT, followed by three times five minutes washing with PBS at RT. Thereafter, peroxidase conjugated secondary rabbit anti mouse Ig was incubated for one hour at RT. After another series of washing steps in PBS at RT (three times five minutes), peroxidase activity was visualized with a diaminobenzidine (DAB; Sigma) staining reaction $(0.5 \mathrm{mg} / \mathrm{ml}$ DAB in PBS/0.1M imidazol $\mathrm{pH} 7.6$ and $0.03 \% \mathrm{H}_{2} \mathrm{O}_{2}$ ), for four minutes at RT. Thereafter, slides were rinsed with MilliQ-water, counterstained, dehydrated and mounted in Entellan (Merck, Darmstadt, Germany). Control incubations included omission of the primary antibodies and incubation with all secundary antibodies.

\section{Immunofluorescence procedure}

For double-label immunofluorescence studies 5 um thick frozen tissue sections from 3 cases, fixed for 5 minutes in acetone, were simultaneously incubated with mouse monoclonal IgM antibodies against lamin A/C, together with either anti-CD3, anti-CD20 or anti-CD 30 antibodies for 45 minutes at $37^{\circ} \mathrm{C}$. Furthermore, monoclonal antibodies against lamin subtypes were also combined with the polyclonal antibody against the Ki-67 antigen. The slides were washed with PBS at RT and for detection of the CD-markers incubated with FITC conjugated goat anti rabbit IgG, FITC labeled goat anti mouse igG2a, or FITC conjugated goat anti mouse lgG1 antibody, respectively, at $37^{\circ} \mathrm{C}$ for 30 minutes. Ki67 antigen was stained with FITC conjugated swine anti rabbit and the lamins were detected with Texas Red labeled goat anti mouse IgM. After each incubation step, slides were washed with PBS at RT. Finally, FITC was amplified with rabbit anti FITC and FITC conjugated swine anti rabbit lg. Slides were dehydrated and nuclei were counterstained with 4,6-diamidino-2-phenylindole (DAPl; Sigma; $1.25 \mathrm{ng} / \mathrm{ml}$ ) in $90 \%$ glycerol, $0.02 \%$ $\mathrm{NaN}_{3}, 10 \% 0.2 \mathrm{M} \mathrm{Tris}-\mathrm{HCl}(\mathrm{pH} 8.0$ ), and 2.0\% 1,4-diazobicyclo-(2.2.2)-octane (DABCO; Sigma) (pH8.0), to reduce photobleaching. 
For triple-label immunofluorescence, anti-CD30, followed by biotin labeled horse anti mouse and AMCA conjugated avidin were first incubated, than the Ki-67 antigen was detected by the polyclonal antiserum, followed by FITC conjugated swine anti rabbit, and finally lamin A/C antibody R27 followed by Texas Red labeled goat anti mouse Igll were applied. Incubations were performed under similar conditions as described above for double-label immunofluorescence. Control incubations included omission of the primary antibodies and incubation with all secundary antibodies. The staining reactions were recordled with a CCD camera, using bright field and fluorescence filters.

\section{Results}

The immunophenotyping results obtained with the lamin antibodies, lymphocyte subtype markers, and Ki-67 as proliferation marker in reactive lymph nodes and of Hodgkin's disease are summarized in table 1 and illustrated in figures 1-8. Antibodies R27 and 41CC4, bath recognizing lamin $A$ and lamin $C$, showed similar reactivity patterns when compared to antibody $133 \mathrm{~A} 2$, recognizing only lamin $A$. The results of the $B$-type lamins were extrapolated by combining results of the lamin immunoperoxidase staining reactions with those from immunofluorescence microscopy for lymphocyte markers and Ki-67.

Table 1. Summary of the immunophenotypes of the different cell types in reactive lympla nodes and Hodgkin's disease.

\begin{tabular}{|c|c|c|c|c|c|c|c|}
\hline & $C D 3$ & $C 020$ & $C D 30$ & $K i-67$ & $\operatorname{Lamin} A / C$ & lamin $B 2$ & tamin $B$ \\
\hline \multicolumn{8}{|l|}{ Reactive lymph nade: } \\
\hline \multicolumn{8}{|l|}{ follicle centre: } \\
\hline centroblasts & m & + & . & + & . & . & + \\
\hline centrocytes & ${ }^{\infty}$ & + & *. & - & * & - & + \\
\hline mantle zone cells & - & + & - & - & ـ & + & + \\
\hline \multirow[t]{4}{*}{ paracortex/medulla cells } & + & - & - & - & - & + & + \\
\hline & - & + & . & . & . & + & + \\
\hline & - & - & - & - & + & + & + \\
\hline & and & nid & + & - & + & + & + \\
\hline \multicolumn{8}{|l|}{ Hodgkin's disease: } \\
\hline \multirow[t]{2}{*}{ Hodgkim/Reed-Stemberg cells } & nd & nd & + & - & 4 & * & + \\
\hline & ndi & nd & + & + & + & $*$ & + \\
\hline \multirow[t]{2}{*}{ surrounding cells } & nod & nd & 。 & * & . & $*$ & + \\
\hline & . & - & . & . & t. & * & + \\
\hline
\end{tabular}

Results obtained after bright field microscopy with peroxidase staining $(n=9)$, double- and triplelabel immunofluorescence microscopy $(n=3)$ and extrapolation. Expression of antigen is indicated by + whereas the lack is represented by -, nd is not determined. When different expression pattems for a cenain cell tyoe occur, than the most common pattern is described first, in order of significance.

Reactive lymph nodes

In the follicle centre few cells scattered through the follicles centre were positive for all three A-type lamin antibodies (fig. 1), while virtually all cells expressed lamin B1 as detected by 119D5 (fig. 2). The centrocytes and centroblasts of the follicle centre were not or very weakly positive for the lamin B2 antibodies (figs. 3 and 4). Mantle zone cells exhibited lamin $\mathrm{B} 1$ and $\mathrm{B} 2$ expression, but were completely negative for the lamin $\mathrm{A}$ and $\mathrm{A} / \mathrm{C}$ antibo- 
dies. The paracortical and medullar cells of reactive lymph nodes showed similar lamin expression patterns, i.e. strong expression of B-type lamins in all cells and A-type lamins in a smaller population of cells (fig. 1). To further specify the A-type lamin expression patterns for the different types of lymphocytes, we performed double- and triple-label immunofluorescence microscopy on the tissue sections. All CD20-positive B-cells in the follicle centre, but also the CD20-positive B-cells outside the follicle, lacked A-type lamins. Additionally, CD3-positive T-lymphocytes in the paracortex and medulla were also negative for A-type lamins. However, activated lymphoid cells with CD30 expression, sparsely seen in the paracortex and medulla, displayed lamins $\mathrm{A} / \mathrm{C}$, although a small subpopulation ( $\pm 10 \%$ ) of CD30 positive cells lacked A-type lamins. Another fraction of the A-type lamin positive cells in the paracortex and medulla remained unidentified by the lymphocyte markers, and mainly represent histiocytes, reticulum, dendritic and endothelial cells but not plasma cells. Proliferative cells were identified by staining with the Ki-67 antibody. Centroblasts in the follicle centre were positive fior $\mathrm{Ki}-67$, whereas centrocytes and the cells of the mantle zone, paracortex and medulla were predominantly negative (fig. 4). In general, A-type lamin expression was mutually exclusive with Ki-67 positivity.

\section{Hodgkin's disease}

The Reed-Sternberg and Hodgkin cells and all surrounding lymphocytes were positive for lamins B1 and B2 in all cases (figs. 5), although the staining intensity of the Reed-Sternberg and Hodgkin cells with the lamin B1 antibody seems lower than the staining intensity of the surrounding cells. A-type lamins were observed in most Reed-Sternberg and Hodgkin cells, while also a population of cells in the background displayed this lamin subtype (fig. 6).

Again, double- and triple-label immunocytochemistry was used to correlate A-type lamin expression with the cellular subtype (Table 2). CD20 positive B-lymphocytes and CD3 positive T-lymphocytes in Hodgkin's disease lacked lamins $A$ and $C_{n}$ which was comparable to the pattern observed in reactive lymph nodes. Again, A-type lamin expression commonly excluded Ki-67 positivity (fig. 7 ).

Furthermore, the majority of CD30 positive lymphoid cells and Reed-Sternberg or Hodgkin cells expressed A-type lamins (Table 2). However, a subpopulation of about $18 \%$ of the lamin $\mathrm{A} / \mathrm{C}$ and $\mathrm{CD} 30$ positive malignant cells showed also Ki-67 expression (fig. 8).

\section{Discussion}

In this study nuclear lamin subtype expression was investigated in specific cell populations of reactive lymph nodes and Hodgkin's disease. Lamin expression of the malignant cells in Hodgkin's disease was compared to the expression in reactive lymph node, in an attempt to obtain further insight into the biology of malignant Reed-Sternberg and Hodgkin cells.

\section{Differential expression of lamins $B 1$ and $B 2$ in reactive $y$ mph nodes}

Distinct areas of reactive lymph nodes exhibit a differential staining pattern for lamins B1 and $B 2$. The CD20 positive centrocytes and centroblasts of the follicle centre, i.e. maturating B-lymphocytes, express high levels of lamin B1, but no or only very low levels of lamin $B 2$, whereas cells of the mantle zone, the paracortex and medulla display both B-type lamins. Our observation implies that lamin $\mathrm{B} 2$ is not constitutively expressed in nucleated cells, in contrast to observations by other investigators $[6,22,23]$. The use of three different lamin B2 antibodies, recognizing both the hypo-and hyperphosphorylated forms of lamin $B 2$ in immunoblotting $[4]$, makes it very unlikely that epitope masking has prevented lamin 
disease expressing muliple phenotypic parameters.

Hodgkin's disease

\begin{tabular}{|c|c|c|c|}
\hline 0030 & $\operatorname{lamin} A C$ & K 167 & Frequency (in \\
\hline & + & $\frac{4}{2}$ & 1.0 \\
\hline & + &. & 15.3 \\
\hline & . & $\div$ & 7.1 \\
\hline & - & - & 76.5 \\
\hline+ & & . & 0.3 \\
\hline+ & & - & 1.0 \\
\hline -. & & + & 7.6 \\
\hline - & & . & 91.1 \\
\hline+ & + & & 0.8 \\
\hline+ & - & & 0.2 \\
\hline - & 4 & & 10.5 \\
\hline . & - & & 89.6 \\
\hline
\end{tabular}

\begin{tabular}{cccc}
\hline \multicolumn{4}{c}{ Hodgkin and Reed-Sternberg cells } \\
\hline CD30 & lamin A/C & K67 & Frequencr (in \%) \\
\cline { 2 - 4 }+ & + & + & 18 \\
+ & + & - & 74 \\
+ & - & + & 4 \\
+ & - & - & 4
\end{tabular}

Results represented as the percentage of 1000 cells counted in double-label immunofluorescence samples and of 50 counted Reed-Sternberg and Hodgkin cells in the triple-label study of three cases.

$\mathrm{B} 2$ recognition in our study $[3,15]$. Furthermore, the strong reactivity of the surrounding cells with these antibodies supports the suggestion that the centrocytes and centroblasts of the follicle centre do indeed not or only very weakly express lamin B2. This suggests that the absence of lamin B2 may be correlated with certain stages of B-cell maturation, because it is lacking only in centroblasts and centrocytes. In contrast, CD20 positive B-lymphocytes in the paracortex and medulla do express lamin B2.

Furthermore, it has been suggested that lamin $\mathrm{Bl}$ expression is correlated with proliferation [4]. Staining with the proliferation marker Ki-67 showed only positivity in the centroblasts and not in the centrocytes. However, lamin B1 was found in both cell types, which is in contrast with the assumed proliferation dependent expression of lamin B1. In conclusion, our observations with respect to B-type lamin expression in the reactive lymph nodes are striking in the light of recent observations in other normal human tissues [1, 4, 6, 21]. Lamin $B^{1}$ is expressed constitutively in the lymphoid cell population, while lamin B2 expression seems correlated with lymphoid cell maturation of the B-cells.

\section{A-type lamin expression in reactive lymph nodes}

Several investigators have observed a lack of A-type lamins in early human hematopoietic cells, such as T-lymphoblasts and pre-B cells ${ }^{[13.25 .29]}$. Cance et al. ${ }^{[6]}$ also demonstrated that proliferating lymphocytes of the germinal centers of lymphoid tissue lacked lamins $\mathrm{A}$ and $\mathrm{C}$. In our study A-type lamins were expressed in a small proportion of cells in reactive lymph nodes. Double-label fluorescence microscopy revealed that Ki-67 positive cells, CD20-positive B-lymphocytes and CD3-positive T-lymphocytes lack A-type lamins, confirming the earlier observations. A few of the lymphoid cells in reactive lymph nodes were CD 30 positive, and most of them expressed A-type lamins. The presence of A-type 


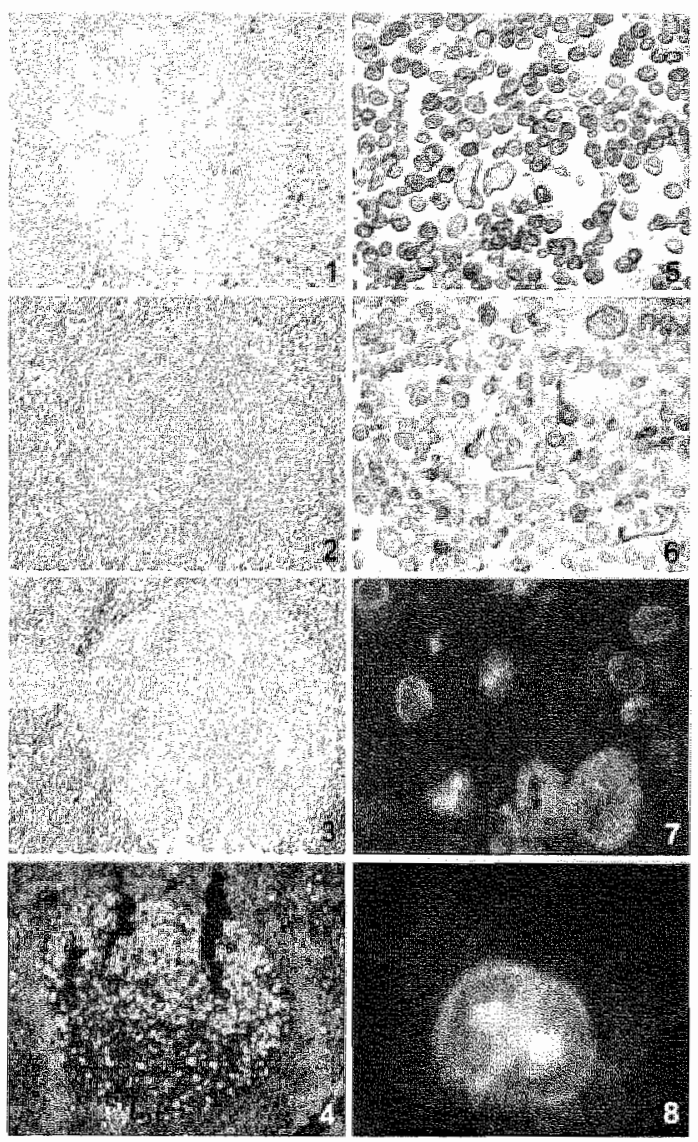

(Flg. 1) Reactive lymph node stained with antibody R27, showing that A-type lamins are present in a few cells of the follicle centre and a population of cells in the paracortex $(x 100)$. (Fig. 2) Staining of the reactive lymph node with antibody 119D5 showing that cells of the follicle centre and the surrounding areas exhibit lamin $\mathrm{B}(\mathrm{x} 100)$. (Flg. 3) The reactive lymph node after antibody LN43 staining, showing that lamin $B 2$ is not or wery weaklly expressed in the celis of the follicle centre (x/00). (Flg. 4) Double. label fuorescence microscopy of a reactive lymph node showing that centroblests of the follicle centre express the proliferation marker Ki-67 (in green) but not lamin B2 (in red), while the majority of the surrounding cells in the mantle zone, paracortex and medulla show the reverse staining pattern, Centrocytes were negative for $K i-67$ and lamin B2. Cc: centrocyte region; cb: centroblast region (x100). (Fig. 5) Reed-Stemberg/Hodgkin cells do express lamin $B 2$, as shown after staining with LN43. Note that surrounding cells stain more strongly (x400). (Fig. 6) Hodgkin lymphoma stained with antibody R27 shows that Reed-Sternberg and Hodginin cells express A-type lamins ( $x$ 400). (Fig.7) Double-label fluorescence microscopy of Hodgkin lymphoma with the proliferation marker $K j 67$ (in green) and antibody 727 for A.type lamins (in red), showing that in general Ki-67 and $A$-type lamin staining are mutually exclusive. DNA was counterstained with DAPI (blue) (x1000). (Fig. 8) Triple-label fluarescence micrioscopy of a CD30-positive Reed-Sternberg cell (in biwe) expressing A-type lamins as detected with antibody $\mathrm{R} 27$ (in red) and the proliferation marker Ki-67 
lamins in these CD30 positive cells suggests that this type of lamin expression may correlate with cell maturation or activation, because CD30 is expressed on mature activated Iymphocytes. Only a minor fraction of CD30 positive lymphoid cells lacks A-type lanins. Moreover, next to these cells a population of histiocytes, reticulum, dendritic and endothelial cells exhibited A-type lamin expression.

Recent studies suggest that, in general, A-type lamin expression is restricted to differentated cells $1.4,6,8,13$. Mature B- and T.lymphocytes of peripheral blood, for example, do display A-type lamins according to Guilly et al. "13]. Ourki-67 study supported the above findings, indicating that A-type lamin expression is limited to the non-proliferative and more mature cell fraction in lymph nodes. Therefore, the presence of A-type lamins in the CD30 positive cells may correlate with the degree of differentiation rather than activation of the cells.

A- and B-type lamin expression in Hodgkin's disease

In general, Reed Sternberg and Hodgkin cells contain lamins $A, C, B 1$ and $B 2$, while the surrounding $B$ - and T-lymphocytes were only positive for both B-type lamins. Reed-Stemberg and Hodgkin cells may be derived from lymphocytes, since recent studies prove the presence of lymphoid markers, such as $V_{H}$ and $V_{L}$ rearrangements, in ReedSternberg and Hodgkin cells ${ }^{[9,14,49]}$. The presence of lamin B2, A-type lamins and CD 30 in the Reed-Stemberg and Hodgkin cells suggests that they show a more differentiated phenotype than the centrocytes and centroblasts or the cells in the mantle zone of a reacm tive lymph node. Strikingly, Reed-Sternberg and Hodgkin cells resembled the lamin phenotype of CD30 positive cells of the paracortex or medulla. This may seem in contrast to the results of Kanzler et al. (1996) ${ }^{[20]}$, who suggested that the malignant cells in Hodgkin"s disease were derived from (crippled) germinal centre B-cells based on VH and VLgene rearrangements. We realize, however, that the Reed-Sternberg and Hodgkin cells may be derived from any lymphoid cell types by terminal differentiation, and hence show A-type lamin expression.

It should be noted that we did not detect centrocyte-and centroblast-llke lamin B2 negative B-cells in Hodgkin lymph nodes. This population seems to be replaced by a population of relatively undifferentiated cells, which may arise from crippled follicle cells and possibly representing the precursors of the Reed-Sternberg and Hodgkin cells. Such crippled cells may initiate differentiation rapidly and aberrantly, resulting in the lack of centrocyteand centroblast-like lamin B2 negative cells in Hodgkin's disease, which upon terminal differentiation result in Reed-Sternberg and Hodgkin cells.

The finding of rare Ki-67 positive Reed-Sternberg and Hodgkin cells confirms that a subpopulation of these malignant cells may proliferate $14,27.31$. However, most Ki-67 positive Reed-Sternberg and Hodgkin cells expressed nex to CD30 al so A-type lamins, indicating that these proliferating cells have a differentiated phenotype. Therefore, these results suggest that several populations of Reed-Sternberg and Hodgkin cells may exist"1"? which differ in their degree of differentiation, activation or proliferative status as shown by the absence or presence of A-type lamins and Ki-67 antigen.

In conclusion. Reed-Siternberg and Hodgkin cells express both A-type and B-type lamins in which they distinguish themselves from the lamin B2 negative centroblasts and centrocytes and the A-type lamin negative mantle zone cells of the reactive lymph nodes. Furthermore, this staining pattern indicates that the malignant cells are more differentiated than these cell types although some of these cells still possess proliferative capacity. 


\section{Aknowledgements}

We thank Annick Haeswovels and Petra Pasman for lechnical advise and staining of tissue sections. Dr. E.B. Lane, Dr. G. Krohne, Dr. Y. Raymond and Dr G. Warren are acknowledged for providing the lamin antbodies. Furthermore, we are grateful to the Nipakiker-Morra Foundation tor financial support.

\section{References}

1. Ausma, J, van Eys, G, Broers, J, Thone, W, Flameng. W, Ramaekers, Fand Borgers, M. Nuclear Iamin expression in chronic hibernating myocardium in man. IMol Cell Cardiol 28: 1297 (1996).

2. Biamonti, $G$, Giacca, M, Perin, G, Contreas, $G$, Zentilin, L, Weighardt, F, Guerra, M, Della-Vallie, $\mathrm{G}, \mathrm{Saccone}, \mathrm{S}$ and Aiva, $\mathrm{S}$. The gene lor a novel humam lamin maps all a highly transcribed locus of chromosome 19 which replicates at the onset of S-phase. Mol Cell Btol 12: 3499 (1992).

3. Bridger, J, Kill, I, O'Farrell, Mand Hutchison, C. Internal lamin structure within G1 nuclei of human dermal fibroblasts. J Cell Sci104: 297 (1993).

4. Broers, J, Machieis, B, Kuijpers, $H_{1}$ Smedts, F, van den Kieboom, R, Raymond, $Y$ and Ramaekers, F. A- and B-type lamins are differentially expressed in normal human tissues. Histochem Cell Biol 107: $505(1997)$.

5. Burke, B, Tooze, G and Warren, G. A monoclonal antibody which recognises each of the nuclear lamin polypeptides in mammalian cells. EMBO J2:361 (1983).

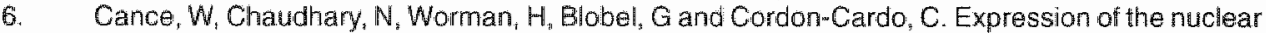
lamins in normal and neoplastic human tissues. J Exp Clin Cancer Res 11:233 (1992).

7. Coates, P, Hobbs, $R$, Crocker,, , Rowlands, D, Murray,, , Quinlan, $R$ and Hall, P. Identification of the antigen recognized by the monoclonal antibody BU31 as lamins $A$ and $C$. J Pathol 178: 21 (1996).

8. Collard, J, Senécall, J and Riaymond, Y. Redistribution of nuclear lamin-A is an early event associated with differentiation of human promyelocylic leukemia HL-60 cells. I Cell Sci 101: 657 (1992).

9. Diehl, $V$, von Kalle, $C$, Fonatsch, $C$, Tesch, $H$, Juecker, M and Schadt, M. The cell of origin in Hodgkin's disease. Semin Oncol 17:660 (1990).

10. Foisner, R and Gerace, L. Integral membrane proteins of the nuclear envelope interact with lamins and chromosomes, and binding is modulated by mitotic phosphorylation. Cell 73: 1267 (1993).

11. Gerace, $L$ and Burke, B. Functional organization of the nuclear envelope. Annu Rev Cell Biol 4: 335 (1988).

12. Glass, $\mathrm{J}$ and Gerace, L. Lamins $\mathrm{A}$ and $\mathrm{C}$ bind and assemble at the surface of mitotic chromosomes. J Cell Biol 111: 1047 (1990).

13. Guilly, M, Kolb, J, Gosti, F, Godeau, F and Courvalin, J. Lamins A and $C$ are not expressed at early stages of human lymphocyte differentiation. Exp Cell Res 189: 145 (1990).

14. Haluska, F, Brufsky, A and Canellos, $G$. The cellular biology of the Reed-Stemberg cell. Blood84: 1005 (1994).

15. Hoger, T, Zatloukal, $K_{n}$ Waizenegger, I and Krohne, G. Characterization of a second highly conserved B-type lamin present in cells previously thought to contain only a single B-type lamin. Chromosoma 100:67(1990).

16. Hozák, P. Sasseville, M-J. Raymond, $Y$ and Cook, P. Lamin proteins form an intemal nucleoskeleton as well as a peripheral lamina in human cells. $J$ Cell Sci 108: 635 (1995).

17. Hummel, M, Zliemann, K, Lammert, H. Piler, S, Sabattini, E and Stein, H. Hodgkin's disease with monoclonal andpolycional populations of Reed-Stemberg cells. N Engl J Med 333: 901 (1995).

18. Hutchison, $\mathrm{C}$, Bridger, $J, C o x, L$ and Kill, I. Weaving a pattern from disparate threads: lamin funcfion in nuclear assembly and IONA replication. J Cell Sci 107: 3259 (1994).

19. Jafte. E. The elusiwe Roed-Sternberg cell N Engl J Med 320:529 (1989).

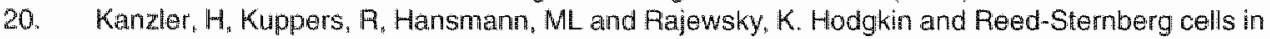
Hodgkin"s disease represent the outgrowth of a dominant tumor clone derived from (crippled) germinal center B cells. J Exp Med 184: 1495 (1996).

21. Machiels, B, Ramaekers, F, Kuijpers, H, Groenewoud, J, Oosterhuis, J and Looijenga, L. Nuclear lamin expression in normal testis and testicular germ cell tumors of adolescents and adults. J Pathol 182: 197 (1997).

22. Moir, R and Goldman, F. Lamin dynamics. Curr Opin Gell Biol 5: 408 (1993).

23. Nigg. E. Assembly and cell cycle dynamics of the nuclear lamina. Semin Cell Biol 3: 245 (1992).

24. Paddy, M, Belmont, A, Saumweber, H, Agard, D and Sedat, J. Interphase nuclear envelope lamins

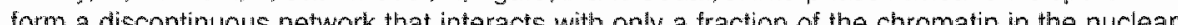


periphery. Cell 62: 89 (1990).

25. Paulin-Lewasseur, $M$, Scherbarth, $A$, Traub, U and Traub, P. Lack of famins A and $C$ m mammalian hemopoilic cell lines devoid of intermediate filament proteins. Eur Cell Biol 47 : 121 (1988).

26. Röber, $\mathrm{F}_{\mathrm{s}}$ Sauter, H, Weber, Kand Osbom, M. Cells of the cellular immune and hemopoiatic system of the mouse lack lamins $\mathrm{AC}$ : distinction versus other somatic cells. J Cell Sol $95: 587$ (1990).

27. Sabattini, E, Gerdes, J, Gherlinzoni, F, Poggi, S, Zucchini, L, Melili, G, Grigioni, F, Del-Vecchio, $M$, Leoncini, $L$ and Falini, $B$. Comparison between the monoclonal antibodies $K i-67$ and $P C 40$ in 125 malignant lymphomas. J Pathol 169: 397 (1993).

28. Schwab, U, Stein, $H_{n}$ Gerdes, J, Lemke, $H$, Kirchner, $H$, Schaadt, M and Diehl, V. Production of a monocional antibady specific for Hodgkin and Stemberg-Reed cels of Hodgkin's disease and a subset of normal lymphoid cells. Nature 299: 65 (1982).

29. Stadelmann, B, Khandjian, E, Hirt, A, Luthy, A, Well, Find Wagner, H. Repression of nuclear lamin $\mathrm{A}$ and $\mathrm{C}$ gene expression in human acute lymphoblastic leukemia and non-Hodgkin"s lymphoma cells. Leuk Res 14: 815 (1990).

30. Trudel, M, Oligny, $L$, Caplan, $S$, Caplan, $C$, Schipper, $H$ and Wang. E. Statin - a novel marker of nonproliferation (Expression in nonneoplastic lymphoid tissues and follicular lymphomas). Am J Clin Pathol 101: 421 (1994).

31. Tsenga, $A$, Korkolopoulou, $P$ Patsouris, E, Pangalis, $G, O$ ates,, Skopelitou, $A$, Elemenoglou, $J$ and Kittas, C. Proliferating cell nuelear antigen, Ki-67, c-myc p62 oncoprotein and nucleolar organizer regions in Hodgkin's disease. Appl Immunohistochem 2: 191 (1994).

32. Zatloukal, $K$, Denk, H, Spurej, $\mathrm{G}$ and Hutter, $\mathrm{H}$. Modulation of protein composition of nuclear lamina reduction of lamins-B1 and lamins-B2 in livers of griseofukin-treated mice. Lab thvest 66:589 (1992). 



\section{Chapter 4}

\section{Chromosomal abnormalities in Hodgkin's disease are not restricted to Hodgkin/Reed-Sternberg cells}

Maurice PHM Jansen, Anton HN Hopman, Annick M Haesevoets, Inge AF Gennotte, Fredrik J Bot, Jan Willem Arends, Frans CS Ramaekers and Harry C Schouten 


\section{Abstract}

Hodgkin and Reed-Sternberg cells are considered to represent the malignant fraction in Hodgkin's disease. Several studies have shown that the Hodgkin and Reed-Sternberg cells are chromosomally abnormal, but genetic data about the morphologically nomal cell population in Hodgkin's disease are very limited. We have, therefore, examined this latter cell population for chromosomal aberrations, using the in situ hybridization (ISH) procedure, making use of DNA probes for chromosomes $1,7,8,9,11,12,15,17$, and 18. Nuclei were isolated from freshly frozen ( 10 cases) and paraffin embedded ( 16 cases) biopsy samples and 1000 nuclei per case were evaluated. The cases of Hodgkin's disease were compared to reactive lymph nodes, which show aberrant chromosome copy numbers in less than $1 \%$ of the cells. Using strict scoring criteria, nuclei in the tumor were found to show an abnormal genotype, in a range of 1 to $12 \%$, with trisomies occuring most frequently. No characteristic numerical chromosome abnormality was observed. ISH on $4 \mu \mathrm{m}$ thick paraffin sections of six cases of Hodgkin's disease revealed numerical aberrations for chromosome 1 in cells which appeared to be morphologically normal. The genomically abnormal nuclei did not differ in morphology and size from nuclei of morphologically normal cells, but differed considerably in size when compared to nuclei of Hodgkin/Reed-Sternberg cells after the ISH procedure. Three of these six cases revealed a population of apparently normall cells with an aberrant copy number which differed notably from the fraction observed in reactive lymph nodes. Our conclusion, therefore, is that a subset of morphologically normal cells, next to the Hodgkin/Reed-Sternberg cells, are chromosomally aberrant and may participate in the malignant cell fraction of Hodgkin's disease.

\section{Introduction}

Hodgkin's disease (HD) consists of an apparently small population of malignant cells, the morphologically distinguished Hodgkin/Reed-Sternberg cells, as well as background cells such as lymphocytes, histiocytes and macrophages, which are considered to be normal (reactive) cells. The frequency of the malignant mononucleated Hodgkin cells and multinucleated Reed-Sternberg cells varies between 1 to $3 \%$ of the total cell population. These cells express the activation marker antigens CD15 and CD30, molecules that are established markers for the immunocytochemical detection of the malignant cells in Hodgkin's disease ${ }^{\mid 9 !}$.

The genotype of Hodgkin's disease has been extensively analyzed by karyotyping is 20.21 $29,34]$ and by flow cytometry $[1,8,17,23]$. Aneuploidy was observed with both techniques and often hyperdiploidy detected. Structural and numerical chromosome aberrations were discovered by karyotyping, but a specific chromosome abnormality could sofar not be characterized in Hodgkin's disease. A method that allows the simultaneous study of the karyotype and immunophenotype revealed an aberrant karyotype in the CD30 positive Hodgkin/Reed-Sternberg cells ${ }^{[9,28.39]}$.

In this study we have applied the in situ hybridization (ISH) technique for the chromosomal analysis of interphase nuclei. The ISH procedure has been used for the detection of specific numerical chromosome abnormalities and the characterization of the frequency of abnormal cells in several other types of malignant tissues ${ }^{15.11 .43 .15]}$. Large populations of interphase nuclei can be evaluated relatively easily for numerical and structural chromosome aberrations by ISH using specific DNA probes ${ }^{\text {113i. }}$

ISH combined with immunophenotyping has been applied before to detect the chromosome copy number in CD30 positive Hodgkin/Reed-Sternberg cells ${ }^{[25]}$. It was reported that in these cells additional chromosome abnormalities were detected with ISH, which were not 
observed by karyotype analysis ${ }^{\text {[al }}$

To our knowiedge hardly any data are available on the ploidy status of the morphologically

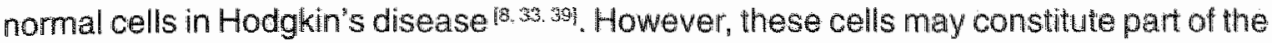
malignant population, as was suggested by the finding of a high aneuploidy fraction in

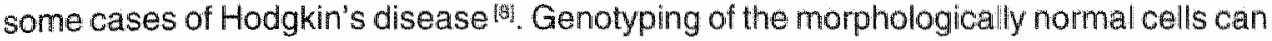
therefore help to further specify the malignant cell population in Hodgkin's disease, and to clarify the relation of these cells to Hodgkin/Reed-Stemberg cells.

\section{Materials \& Methods}

Tissue samples

Paraffin embedded $(n=16)$ and frozen $(n=10)$ biopsy specimens from 21 patients with Hodgkin's disease, and paraffin embedded $(n=6)$ and frozen $(n=10)$ biopsy specimens of reactive lymph nodes were analyzed by single-target ISH. These cases of Hodgkin's disease were histologically classified as nodular sclerosis $(n=12)$, nodular sclerosis lymphocyte depleted $(n=2)$, mixed cellularity/lymphocyte depleted $(n=1)$, mixed cellularity $(n=4)$ and lymphocyte depleted $(n=2)$.

\section{Preparation of nuclei from freshly frozen biopsies}

Nuclei were isolated from $50 \mu \mathrm{m}$ thick sections of frozen biopsy material. The sections were digested with $100 \mathrm{mg} / \mathrm{ml}$ pepsin from porcine stomach mucosa $(2,500-3,500$ units per mg protein; Sigma, St. Louis, MO, USA) in $0.01 \mathrm{~N} \mathrm{HCl}$ for 20 minutes at $37^{\circ} \mathrm{C}$. The digest was cytospinned (Cytospin3, Shandon Scientific Limited, Astmoor, England) for 5 minutes at 700 rpm onto poly-L-lysine (MW 150,000; Sigma) coated glass slides and airdried. Acidic dehydration of slides was performed with $70 \%$ ethanol $/ 0.01 \mathrm{~N} \mathrm{HCl}$ to preserve nuclear morphology. The slides were post-fixed in $1 \%$ paraformaldehyde/0.1M phosphate buffer ( $\mathrm{pH}$ 6.0) for 10 minutes at $4^{\circ} \mathrm{C}$ and subsequently washed in phosphate buffered saline (PBS) pH 7.4, dehydrated in an ascending ethanol serie and air-dried.

\section{Sample preparation from paraffin embedded biopsies}

Isolation of nuclei from $50 \mu \mathrm{m}$ thick sections of paraffin embedded biopsy samples was performed by a method modified from Hedley et all." ${ }^{10 !}$ and Schutte et al. " ${ }^{50 \mid}$. The sections were enzymatically digested for 20 minutes at $37^{\circ} \mathrm{C}$ with $4 \mathrm{mg} / \mathrm{ml}$ pepsin in $0.2 \mathrm{~N} \mathrm{HCl}$. The digest was cytospinned for 5 minutes at $700 \mathrm{rpm}$ onto poly-L-lysine coated glass slides and air-dried. Acidic dehydration of slides was performed with $70 \%$ ethanal/0.01 $\mathrm{N} \mathrm{HCl}$ to preserve nuclear morphology, and subsequently washed in PBS, dehydrated and air-dried.

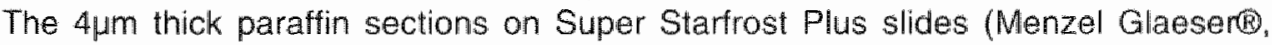
Braunschweig, Germany) were treated with $1 \mathrm{M}$ sodium thiocyanate at $80^{\circ} \mathrm{C}$ for 10 minutes and digested with $4 \mathrm{mg} / \mathrm{ml}$ pepsin in $0.2 \mathrm{~N} \mathrm{HCl}$ at $37^{\circ} \mathrm{C}$ for 5 to 20 minutes, as described by Hopman et al. $|14|$.

\section{DNA probes}

Probes utilized in the $1 \mathrm{SH}$ analysis hybridize to the (peri)centromeric regions of human

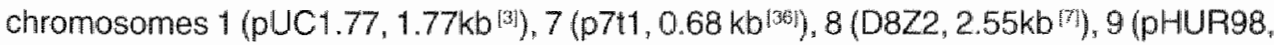

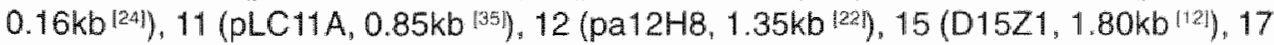
$\left(\mathrm{p} 17 \mathrm{H} 8,2.7 \mathrm{~kb}^{[37}\right)$, and $18\left(\mathrm{L1} .84,0.68 \mathrm{~kb}^{(\mathrm{a})}\right)$. These probes were labeled by a standard nick-translation reaction with biotin-11-dUTP (Sigma) according to the supplier's instructions. Probes for chromosome 1 and 8 were also labeled with FITC-11-dUTP (Boehringer, Mannheim, Germany) for the double-target ISH procedure. 
In situ hybridization and immunocytochemistry

The DNA probes were diluted with hybridization buffer $(60 \%$ formamide, $2 \times S S C \mathrm{pH} 7.0$, $10 \%$ dextran sulphate, $0.2 \mathrm{mg} / \mathrm{ml}$ herring sperm DNA as carrier DNA and $0.2 \mathrm{mg} / \mathrm{ml}$ yeast IRNA as carrier RNA) to a final concentration of $0.4 \mathrm{ng} / \mathrm{ml}$ for pUC 1.77 and $1 \mathrm{ng} / \mathrm{ml}$ for all other autosomal probes. Ten microliters of hybridization mixture were added to the slides under a coverslip. Samples from frozen biopsy material were then denaturated in a moist chamber at $70^{\circ} \mathrm{C}$ for 3 minutes, while samples from paraffin embedded material were denaturated at $80^{\circ} \mathrm{C}$ for 5 minutes. Hybridization was performed overnight at $37^{\circ} \mathrm{C}$. After hybridization, samples were washed twice for 5 minutes in $60 \%$ formamide, $2 \times S S C$ pH 7.0 , at $42^{\circ} \mathrm{C}$, twice for 5 minutes in $2 \times S S C ~ p H 7.0$, at $42{ }^{\circ} \mathrm{C}$, and once in $4 \times S S C /$ $0.05 \%$ Tween 20 buffer for 5 minutes at room temperature. The biotinylated probes in the single-target FISH were detected according to the procedure of Pinkel et al. ${ }^{[27]}$, in subsequent incubations with fluorescein isothiocyanate (FITC) conjugated avidin (AvFITC; Vector, Brunschwig Chemie, Amsterdam, The Netherlands), biotin-conjugated goat antiavidin (BioGaA; Vector) and again FITC-Conjugated avidin, all for 20 minutes at $37^{\circ} \mathrm{C}$ in a $1: 100$ dilution. Nuclei were counterstained with propidium iodide ( $\mathrm{Pl}$, Sigma; $0.5 \mathrm{mg} / \mathrm{ml}$ ) or 4-,6-diaminidino-2-phenylindole (DAPI; Sigma; $1.25 \mathrm{ng} / \mathrm{ml}$ ), both diluted in glycerol containing 2.3\% 1,4-diazobicyclo-(2.2.2.)-octane (DABCO; Sigma). The biotinylated probes in the double-target ISH were detected by subsequent incubations with TexasRedconjugated avidin (Vector), biotin conjugated goat anti-avidin and TexasRed-conjugated avidin. FITC-labeled probes were enhanced with rabbit anti-FITC (DAKO A/S, Glostrup, Denmark) and swine anti-rabbit conjugated FITC (DAKO A/S). Afterwards, nuclei were counterstained with DAPI. In parallel, the $\mathrm{ABC}$ method ${ }^{16 !}$ ! was applied for detection, with the peroxidase activity being visualized with a diaminobenzidine (DAB; Sigma) staining reaction. These slides were counterstained with haematoxylin, dehydrated and mounted in Entellan (Merck, Darmstadt, Germany).

CD30 staining was performed with the anti-CD30 antibody Ber-H2 on $4 \mu \mathrm{m}$ paraffin sections (DAKO A/S). Sections were proteolytically digested with $0.5 \%$ trypsin (Sigma) in $0.1 \%$ $\mathrm{CaCl}_{2}$ for 30 minutes at $37^{\circ} \mathrm{C}$ before Ber- $\mathrm{H} 2$ was applied in a dilution of $1: 20$. The antibody was detected with biotin-conjugated horse anti-mouse (Vector) and the $\mathrm{ABC}$ method and demonstrated with a DAB-reaction.

\section{Data evaluation}

All slides were evaluated and scored following the criteria set by Hopman et al. ${ }^{113.14 !}$. According to these criteria, a correct evaluation includes only cells with proper nuclear morphology, while overlapping nuclei are excluded. One thousand nuclei per chromosome per case were analyzed in order to detect small populations $(1-5 \%)$ of chromosomally abnormal nuclei. Reactive lymph nodes were studied to determine the frequency of numerical chromosome aberrations in normal tissue. The average frequency of nuclei with an abnormal chromosome count in ten reactive lymph nodes was calculated. This average value plus three times the standard deviation was defined as the cut-off limit, thereby setting the diagnostic threshold. The number of aberrant nuclei in Hodgkin's disease samples was regarded as substantially different from the normal lymph nodes when their frequency exceeded this cut-off limit.

The area size of nuclei was determined on basis of haematoxylin stained nuclei after ISH. For this, the border of the nucleus was specified manually in an image recorded with the ISIS program of Metasystems (CCD S30 camera, Sandhausen, Germany). The area size was afterwards calculated with this program. 


\section{Results}

\section{$1 S H$ on isolated nuclel}

Ten frozen reactive lymph nodes and ten frozen samples of Hodgkin's disease were analyzed with nine different chromosome probes to determine the frequency of chromosomally abnormal cells. Nearly all nuclei in the reactive lymph nodes could be evaluated, showing a fraction of nuclei with an increased chromosome copy number varying between $0.1 \%$ and $0.2 \%$, producing cut-off limits ranging from $0.3 \%$ to $0.8 \%$ for the individual chromosomes.

Using the ISH scoring criteria as described, frequencies of nuclei with aberrant chromosome copy numbers in Hodgkin's disease varied from $1 \%$ to $5 \%$ on average, with two cases showing even higher frequencies of aberrations for chromosome 1, i.e. $7 \%$ and $12 \%$ (fig. 1.2a). All cases of Hodgkin's disease exhibited a gain for at least four chromosomes, with trisomies for these chromosomes being detected most frequently. Figure I also shows that the frequency of cells exhibiting abnormal copy numbers varied for the different chromosomes in the individual cases. For example, the two cases with high frequencles of abnormal nuclei for chromosome 1, i.e. $7 \%$ and $12 \%$, showed aberrations for chromosome 8 in only $4 \%$ and $2 \%$ of the cells, respectively, and only in $5 \%$ and $3 \%$ of the cells for chromosome 11, respectively. Furthermore, the former case was analysed with double-target ISH combining probes for chromosomes 1 and 8,1 and 11 , and 8 and 11 . Double-target ISH showed different chromosome constitutions in the abnormal nuclei (fig. 1a-i). Some nuclei had an aberrant copy number for only one chromosome (fig. 1a-f), whereas others displayed abnormalities for both chromosomes (fig. 1g-i). However, a proper determination of the frequencies of abnormal nuclei in the double-target ISH was not possible due to the low frequencies of the subfractions. Since all cases of Hodgkin's disease showed a numerical aberration for chromosome 1 in a relatively large fraction of nuclei isolated from frozen tissue sections, the cell types in which these chromosome aberrations occur were examined in more detail. However, not all nuclei of the Hodgkin/ Reed-Stemberg cell population could be evaluated in the suspensions obtained from frozen biopsies, because of overlap or loss of morphology (fig. 2b). Therefore, ISH was performed on nuclei suspensions isolated from paraffin embedded biopsy material in an attempt to circumvent the loss of morphology. Five reactive lymph node samples and seven cases of Hodgkin's disease were investigated. The cut-off limit for nuclei with a gain for chromosome 1 was established at $1 \%$, on basis of the frequency of numerically aberrant cells in nuclel suspensions. Furthermore, in these samples more than $95 \%$ of the nuclei could be evaluated for ISH results because nuclear overlap and truncation were not hampering the analyses. Nuclei suspensions of six Hodgkin cases revealed fractions of nuclei with abnormal chromosome copy numbers ranging from $2 \%$ to $10 \%$, which exceeded the threshold. However, nuclei from Reed-Sternberg cells might have been excluded in these evaluations as the result of nuclear overlap.

Based on the results on isolated nuclei from frozen and paraffin embedded biopsies, chromosome abnormalities in morphologically normal cells were anticipated. To prove that "normal" cells were chromosomally aberrant, ISH was performed on tissue sections to correlate cellular morphology -normal versus tumor cells- with the chromosome constitution.

\section{ISH on paraffin embedded biopsies}

CD30 staining and bright-field ISH for chromosome 1 were pertormed on parallel paraffin sections of sixteen cases of Hodgkin's disease to further characterize the chromosome copy numbers in tumor cells and morphologically normal cells. Determination of the cut-off limit in paraffin sections of reactive lymph nodes was complicated by nuclear truncation 


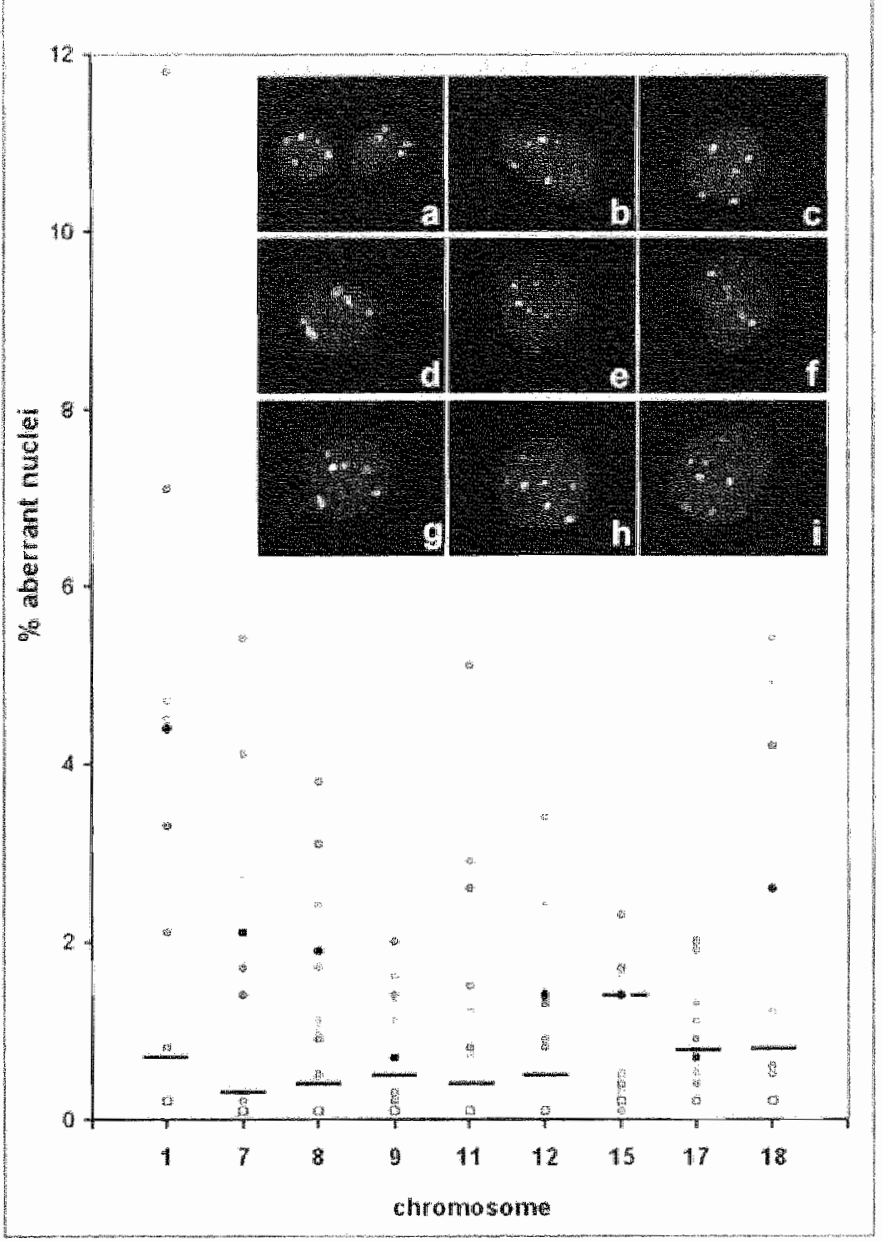

Figure 1. Results obtained with nuclei suspensions isolated from biopsy mateilal of ten reactive lymph nodes and ten cases of Hodgkin's disease after fluorescence in situ hybridization. One thousand nudei per chromosome per case were evaluated for nucle with more than $215 \mathrm{H}$. signals. Average () and cut-off limits (-) represent the values obtained from ten reactive lymph nodes. The colored dots symbolize the analyzed cases of Hodgkin's disease. The cases of Hodgkin's disease which exceed the cut off limit are significantly aberrant. The insert (magnification $\times 1000$ ) shows the results of the double target ISH of a Hodgkin's disease case (puple-blue dof) with $7 \%$ abnormal nuclei for chromosome $1,4 \%$ aberrant nuclei for chromosome 8 and $5 \%$ abnormal nuclei for chromosome 11 in the single-target ISH. Double-target ISH was performed for chromosome 1 (green) and 8 (red) [a,d,gl, chromosome 1 (green) and 11 (red) $[\mathrm{b}, \mathrm{e}, \mathrm{h}$ ], and chromosome 8 (green) and 11 (red) [c, li, Chromosome aberrations for individual chromosones are illustrated for chromosome $1[a, b]$, chromosome $8[\mathrm{c}, \mathrm{d}]$, and chromosome 1fle.f]. Furthermore, nuclei are numerical abnormal for chromosome 1 and $8[\mathrm{~g}]$ ], 1 and $11[\mathrm{~h}]$, and 8 and $11[i]$. For color illustration see page 99. 
and nuclear overlap. For this reason we only evaluated nuclei which could be recognized as individual nuclei without any overlap. Following this approach in reactive lymph node sections, only very few aberrant nuclei were obsenved (always less than $1 \%$ ). Therefore, it seemed realistic to use the cut-off level which was also used in nuclei suspensions.

Nine cases with typical examples of large (multi)nucleated Hodgkin/Reed-Sternberg cells, CD30 positive in the serial sections, had tumor cells with copy number gains for chromosome 1. Figure 2d illustrates CD30 positive Hodgkin and Reed-Sternberg cells and the same area in figure $2 e$ demonstrates cells with trisomies for chromosome 1 which appear to be morphologically normal cells. Reed-Sternberg cells with multiple copies for chromosome 1 are presented in figure $2 e, f, h$. Moreover, as shown in figure $2 f$, nuclei from Hodgkin/Reed-Sternberg cells, with an average nuclear surface area of $195.6 \mu \mathrm{m}^{2} \pm 66$ $\mu \mathrm{m}^{2}(n=8)$ were considerably larger than the nuclei of normal cells with an average nuclear surface area of $24.6 \mu \mathrm{m}^{2} \pm 8.4 \mu \mathrm{m}^{2}(n=300)$. In six cases a gain in chromosome 1 copy number was observed in a fraction of cells with an average nuclear surface area of 30.6 $\mu \mathrm{m}^{2} \pm 8.4 \mu \mathrm{m}^{2}(\mathrm{n}=26)$, i.e. morphollogically normal appearing cells (fig. $\left.2 \mathrm{c}, e, f_{n}, i\right)$. It is obvious that in normal cells nuclear truncation in $4 \mu \mathrm{m}$ thick tissue sections is limited as compared to Hodgkin/Reed-Sternberg cells. Consequently, the detected chromosome copy number represents more accurately the true copy number of chromosomes in morphologically normal cells than in tumor cells.

The results of the paraffin sections of the six cases with chromosome abnormalities in morphologically normal appearing cells are described in detail below.

Case 1: CD30 staining of paraffin sections detected $0.3 \%$ of CD30 positive Hodgkin/ Reed-Sternberg cells. Based on morphological criteria $0.2 \%$ Hodgkin/Reed-Sternberg cells were identified after ISH on paraffin sections and evaluation of 6777 nuclei. In $50 \%$ of these tumor cells three and four ISH-signals per nucleus (55\% and $45 \%$, respectively) were observed for chromosome 1. Moreover, a numerical chromosome abnormality was observed $0.5 \%$ of morphologically normal cells.

Case 2: ISH evaluation of 1600 nuclei in paraffin sections exhibited $1.2 \%$ Hodgkin/ Reed-Sternberg cells. A numerical chromosome abnormality was observed in $65 \%$ of these cells with three, four and more $\mathrm{ISH}$-signals per nucleus in a frequency of $77 \%, 15 \%$ and $8 \%$, respectively. Morphologically normal appearing cells with three ISH-signals were detected in $0.7 \%$ of the total cell population.

Case 3: The frequency of CD30 positive Hodgkin/Reed-Sternberg cells after CD30 staining was $0.8 \%$. Evaluation of 4443 nuclei after ISH demonstrated $0.6 \%$ Hodglkin/ReedSternberg cells on basis of morphology, with $42 \%$ of these cells having a numerical chromosome abnormality. Three and more ISH-signals per nucleus were observed in $80 \%$ and $20 \%$ of these latter cells, respectively. Three ISH-signals were also observed in $1 \%$ of the cells which appeared to be morphologically normal.

Case 4: CD30 staining identified $0.7 \%$ of CD30 positive Hodgkin/Reed-Sternberg cells. Five thousand nuclei were evaluated for ISH-signals, which revealed $0.8 \%$ Hodgkin/Reed= Sternberg cells according to nuclear morphology. More than two signals were observed in $33 \%$ of these tumor cells and the cells had three or four $1 \mathrm{SH}$-signals per nucleus $(77 \%$ and $23 \%$, respectively). A fraction of $1.2 \%$ morphologically normal appearing cells showed three ISH-signals in their nuclei. 
Case 5: Evaluation of 2000 nuclei after ISH exhibited 1.4\% Hodgkin/Reed-Sternberg cells, based on morphological criteria. More than two signals were observed in $79 \%$ of these tumor cells. Hereby, three, four or more ISH-signals per nucleus were detected in a frequency of $48 \%, 22 \%$ and $30 \%$, respectively. In $1.9 \%$ of morphologically normal cells three $1 \mathrm{SH}$-signals were observed.

Case 6: CD30 staining identified 2.2\% Hodgkin/Reed-Stemberg cells. After evaluation of 3054 nuclei in paraffin sections by means of $1 \mathrm{SH}, 1.9 \%$ of Hodgkin/Reed-Sternberg cells were detected. In $74 \%$ of these Hodgkin/Reed-Sternberg cells three, four or more 1SH-signals per nucleus ( $64 \%, 21 \%$ and $14 \%$, respectively) were observed. Morphologically normal appearing cells with three signals for chromosome 1 were detected in $2.3 \%$ of the total cell population.

\section{Discussion}

Many studies using different techniques have demonstrated that the malignant Hodgkin/ Reed-Sternberg cells in Hodgkin's disease are chromosomally aberrant. The chromosome status of the morphologically normal cells, however, was less clear until now. Teerenhovi et al. ${ }^{1331}$ reported that only normal karyotypes were observed in B-and T-lymphocytes of Hodgkin's disease. However, using flow cytometry Erdkamp et al. ${ }^{[8 \mid}$ demonstrated that the aneuploid cell fraction in some cases of Hodgkin's disease was larger than the frequency of Hodgkin/Reed-Sternberg cells, thus implying that morphologically normal cells might also belong to the aneuploid population. Weber-Matthiesen et al. "387, combining FISH with CD30 staining on fresh tumor material, were the first to report that very few of the apparently normal lymphocytes had lost the $Y$ chromosome, but did not regard these lymphocytes as being chromosomally abnormal ${ }^{[39 !}$. Finally, Nolte et al. ${ }^{[25]}$, using the same technique on paraffin sections, reported that chromosome aberrations were limited to the Hodgkin/ReedSternberg cells.

In the present study we have focused on the numerical chromosome constitution of the morphologically normal cells in Hodgkin's disease. In nuclei isolated from frozen and paraffin material $1-12 \%$ of chromosomally abnormal nuclei were observed in the single-target ISH. However, not all nuclei of the Hodgkin/Reed-Sternberg cell population could be evaluated due to the employed evaluation criteria, because of overlap or loss of morphology. Despite this fact, the number of abnormal nuclei detected in the suspensions from Hodgkin's disease exceeded the expected number of Hodgkin/Reed-Sternberg cells in virtually all cases. Furthermore, it cannot be excluded that the frequency of numerical aberrations is considerably higher since chromosomes not yet tested may be numerically altered. Also abnormal chromosomes lacking the centromere may not become visible with the applied technique. Therefore, a relatively large fraction of chromosomally abnormal nuclei may be ascribed to the morphologically normal cell population in Hodgkin's disease.

To prove this assumption, $4 \mu \mathrm{m}$ thick paraffin sections were investigated with ISH and serial sections stained with CD30. Clear evidence was obtained that a proportion of cells surrounding Hodgkin/Reed-Sternberg cells contained numerical chromosome aberrations. When genomically abnormal CD30 negative cells were found in the neighbourhood of CD30 positive Hodgkin/Reed-Sternberg cells, their differences in immunophenotype and size were clearly demonstrated. The Hodgkin/Reed-Sternberg cells revealed high copy numbers for chromosome 1 after ISH. However, the genuine chromosome copy number of these cells is difficult to assess in paraffin sections due to nuclear truncation, resulting in an underestimation of the chromosome copy number ${ }^{[14,26]}$. This nuclear truncation is 


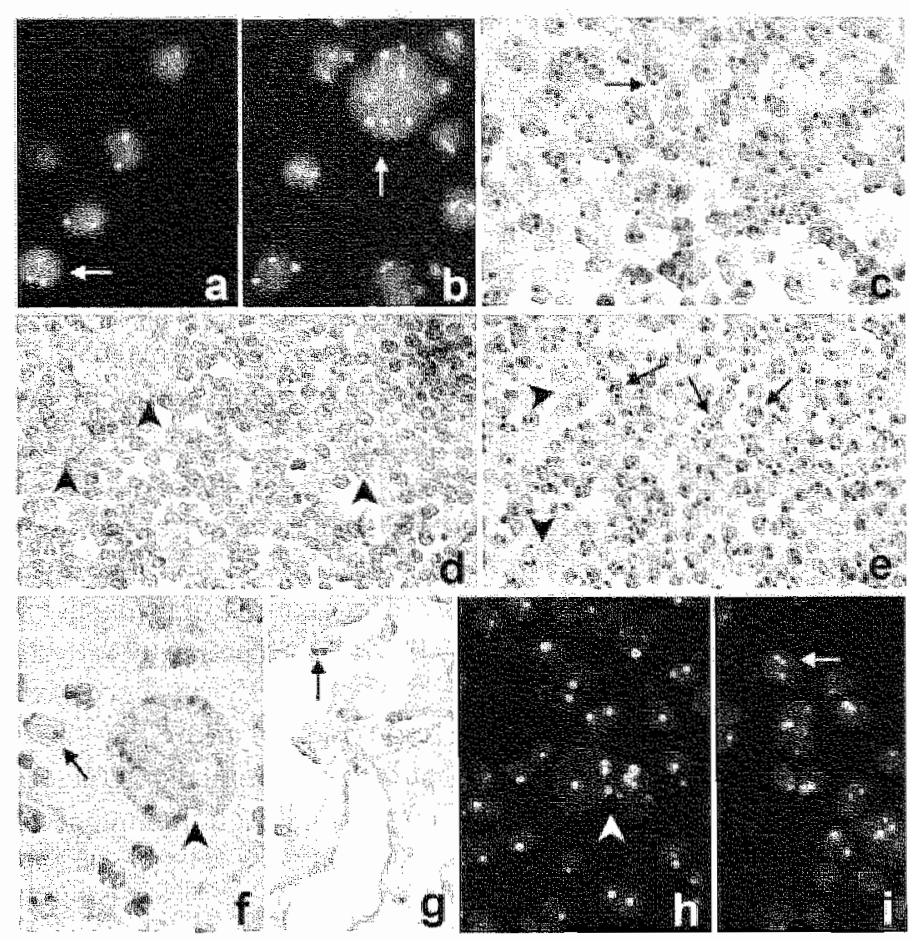

Figure 2. [a,b] Nuclel isolated trom frozen biopsy sample of Hodgkin's disease (nodular sclerosis). In [a] the arrow points to a nucleus with a trisomy for chromosome 1. The arrow in [b] marks a nucleus that was not evaluated because of the loss of morphology or overlap. This nucleus or nuclei may, however, belong to a Hodgkin or Feed-Stemberg cell. [c] A $4 \mu m$ thick paraffin section of Hodgkin's disease (nodular sclerosis) after ISH with chromosome 1 showing a small nucleus with a numerical chromosome abnormality (arrow). [d,e] CD30 positive Hodgkin/Feed-Stemberg cells in 4 um thick serial paraffin sections of Hodgkin's disease (nodular sclerosis). Arrow heads indicate Reed-Sternberg cells [d], of which some are also seen in [e]. Black arrows in [e], however, show nuclei from morphologically nomal cells (see [d]) with a numerical aber ration for chromosome 1. [f-1] Bright-field and fluorescence ISH on paraffin sections of mixed cellularity Hodgkin's disease. Clear differences in morphology and size between nuclei from a Reed-Stemberg cell and a morphologically normet cell (arrow) are illustrated in [f]. Both nuclei have multiple copies for chromosome 1. Figure [g] shows other nuclei from morphologically normal cells with trisomies for chromosome 1 . Finally, $[h$, il $]$ demonstratie chromosomally abnormal nuclei atter FISH from Hodgkin/Rieed-Stemberg cells (arrow head) [h] and a morphologically normai cell (arrow) [1], respectively. (Magnification $\times 400$ ). For color illustration see page 100.

correlated with the size of nuclei and the section thickness. Thus, nuclei from nomal cells are less affected by truncation than large nucleifrom Hodgkin/Reed-Stemberg cells (about eight times the size of the normal nuclei), because the size of nucleif from normal cells is in the range of the section thickness. In addition, the observed chromosome copy number in morphologically normal cells represents more accurately the genuine copy number of the chromasomes.

The frequency of morphologically normal cells with an aberrant copy number for 
chromosome 1 in paraffin sections of Hodgkin's disease ranged from $0.5 \%$ to $2.3 \%$. These cases clearly showed normal cells with chromosome abnormalities on basis of a distinguished morphology and $1 \mathrm{SH}$-signal distribution. In three cases the frequency of $1.2 \%$, $1.9 \%$ and $2.3 \%$ of cells with an aberration for chromosome 1 was higher than the cut-off limit ( $1 \%$ ) assessed in nuclei suspensions of reactive lymph nodes. The cut-off limit for paraffin sections, however, may differ from the threshold for suspensions of nuclei. An underestimation of the cut-off limit will occur in paraffin sections because of loss of signals as a result of truncation. For this reason a statistical analysis was difficult to apply in sections. The observed genomic changes in morphologically normal cells may be clonal, but may also be the result from a genetic instability [?]. Weber-Matthiesen et al. "39]) showed that also Hodgkin/Reed-Stenberg cells exhibit a chromosome instability, as these cells have different abnormal copy numbers for a chromosome. Our single-target ISH results of nuclei suspensions suggests that nuclei with numerous chromosome constitutions may be present. This chromosome instability was confirmed in our double-target ISH in which nuclei with varlous combinations of numerical chromosome abnormalities were present. Our finding that morphologically normal cells in Hodgkin's disease attain genomic changes are supported by the data of Kapp et all. "19l and Wolf et al. "10!, who observed that Hodgkin's disease-like lesions in SCID-mice may have been derived from EBV-infected bystander cells [|3|. Furthermore, these authors found that from peripheral blood mononuclear cells a cell line with Hodgkin/Reed-Sternberg cell characteristics can be obtained ${ }^{(40)}$. This also suggests that precursors of the malignant Hodgkin/Reed-Sternberg cells are amongst the morphologically normal cells.

These morphologically normal cells are randomly scattered throughout the tissue section and sometilmes located in the vicinity of Hodgkin/Reed-Sternberg cells, suggesting that they might originate from T- or B-lymphocytes. However, more studies should be done in order to characterize their immunophenotype and immunoglobulin (lg) gene rearrangernents. Immunophenotyping is necessary to define their cellular origin, whereas Ig gene rearrangement analysis should verify whether Hodgkin/Reed-Sternberg cells are derived from these chromosomally abnormal cells. However, until now we were not able to successfully combine in situ hybridization with immunocytochemistry using enzymatic reactions for bright-field microscopy, due to immunocytochemical shielding of the nuclei by the precipitation product 31.32 .

Although we realize that our data may be controversial in comparison with other reports in literature we strongly feel that the compelling evidence presented here supports the idea that the malignant cell population is not limited to the Hodgkin/Reed-Sternberg cells, but also includes a subset of morphologically normal appearing cells in these lesions.

\section{Heferences}

1. Anastasi, d, Bauer, KD and Variakojis, D. DNA aneuploidy in Hodgkin's disease. A multiparameter flow-Cytometric analysis with cytologic correlation. Am J Pathol 128: $573(1987)$.

2. Barrios, L, Cabalin, MP, Miro, R, Fuster, $\mathcal{C}$, Berrozpe, G, Subias, A, Batle, X and Egozcue, J. Chromosome abnormalities in peripheral blood lymphocytes from untreated Hodgkim's patients. Hum Genet 78: 320 (1988).

3. Cooke, Hand Hindley, J. Cloning of human satellite III DNA: different components are on different chromosomes. Nucleic Acid Res 6: 3177 (1979).

4. Devilee, P, Cremer, T, Slagboom, P, Bakker, E, Scholl, H, Hager, H, Stevenson, A, Cornelisse, C and Pearson. P. Two subsets of human alphoid repetitive DNA show distinct preferential localization in the pericentromeric regions of chromosomes 13, 18, and 21. Cytogenet Cell Genet 41: 


\section{$193(1986)$}

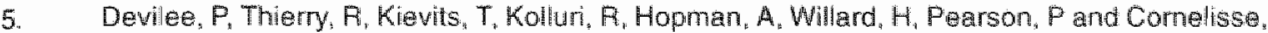
C. Detection of chromosome aneuploidy in interphase nuclei from human primary breast tumors using chromosome-specific reperitive DNA probes. Cancer Res 48: $5825(1988)$.

6. Dohner, $H, B$ Bloomfield, $C$, Frizzera, $G$, Frestedt, $J$ and Arthut, D. Recurring chromosome abnormalities in Hodgkin's disease. Genes Chromosom Cancer 5: 392 (1992).

7. Donion, T, Wyman, A, Muholland, J, Barker, D, Bums, G, Latt, S and Botstein, D. Alpha satellite-like sequences at the centromere cif chromosome 8. Am J Hum Genet 39: A 196 (1986).

8. Erdkamp, $F$, Schouten, $H$, Breed, W, Janssen, W, Hoffmann, $d$, Schutte, B and Bliham, G. DNA aneuploidy in Hodgkin's disease: a mutiparameter flow cytometric analysis. Leuk Lymphoma 12: 297 (1994).

9. Haluska, F. Brufsky A and Canellos, G. The celluiar biology of the Reed-Stemberg cell. Blood 84: $1005(1994)$.

10. Hedley, D, Friedlander, M, Taylor, I, Rugg, C and Musgrove, E. Method for analysis of cellular DNA content of paraffin-embedded pathological material using flow cytometry. I Histochem Cytochem 31: 1333 (1983).

11. Herbergs, $J$, de-Bruine, A, Marx, $P$, Vallinga, $M$, Stockbrugger, $R$, Ramaekers, $F$, Arends, $J$ and Hopman, A. Chromosome aberrations in adenomas of the colon. Prool of trisomy 7 in tumor cells by combined interphase cytogenetics and immunocytochemistry. Int J Cancer 57: 781 (1994).

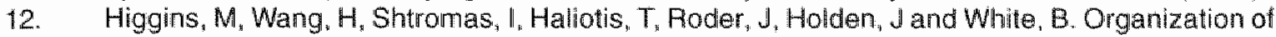
a repetitive human $1.8 \mathrm{~kb} \mathrm{Kpnl}$ sequence locialized in the heterochromatin of chromosome 15. Chromosoma 93: 77 (1985).

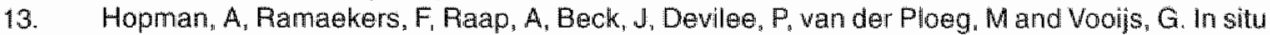
hybridization as a tool to study numerical chromosome aberrations in solid bladder tumors. Histochemistry 89: 307 (1988).

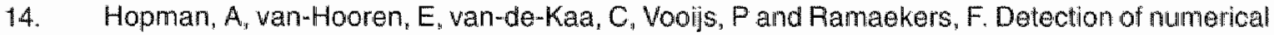
chromosome aberrations using in situ hybridization in paraffin sections of routinely processed bladder cancers. Mod Pathol 4: 503 (1991).

15. Hopman, A. Voorter, C and Ramaekers, F. Detection of genomic changes in cancer by in situ hybridization. Mol Biol Rep 19: 3\# (1994).

16. Hsu, S, Raine, L and Fanger, H. Use of avidin-biotin-peroxidase complex (ABC) immunoperoxidase techniques: a comparison between $\mathrm{ABC}$ and unlabeled antibody (PAP) procedures. J Histochem Cytochem 29:577 (1981).

17. Joensiu, $H$, Klemi, P and Korkeila, E. Prognostic value of DNA ploidy and proliferative activity in Hodgkin's disease. Am J Clin Pathol 90: 670 (1988).

18. Kapp, U, Wolf, J, Hummel, M, Pawlita, M, won-Kalle, $C$, Dallenbach, F, Schwonzen, M, Krueger, G, Muller-Lantzsch, N, Fonatsch, $C$ and al., e. Hodgkin's lymphoma-derived tissue serially trans: planted into severe combined immunodeficient mice. Blood 82: 1247 (1993).

19. Knuutila, $S$, Teerenhovi, L, Larramendy, M, Elonen, E, Franssila, K, Nylund, S, Timonen, $T$, Heinonen, $K$, Mahlamaki, E, Winqwist, R and Rutu, T. Colll lireage involvement of recurrent chromosomal abnormalities in henualologic neoplasms. Genes Chromosom Cancer 10:95 (1994). Koduru, PR, Susin, M, Schulman, P, Catell, D, Goh, JC, Karp, Land Broome, J. Phenotypic and genotypic characterization of Hodgkin's disease. Am J Hematol 44:117 (1993).

21. Ladany, M, Parsa, N, Offit, K, Wachtel, M, Filippa, D and Jhanwar, S. Clonal cytogenetic abnormalities in Hodgkin's disease. Genes Chromosom Cancer 3: 294 (1991).

22. Looijenga, L, Smit, $V$ and Wessels, J. Localization and polymorphism of a chromosome 12. specitic alpha satellite DNA sequence. Cytogenet Cell Genet 54: 216 (1990).

23. Morgan, $K$, Quirke, P, O'Brien, $C$ and Bird, $C$. Hodgkin's disease: a llow cytometric study. J Clin Pathol 41: 365 (1988).

24. Moyzis, $R$, Albright, $K$, Bartholdi, M, Cram, L, Deaven, $L$, Hildebrand, $C$, Joste, $N$, Longmire, $J_{1}$ Meyne, J and Schwarzacher-Robinson. T. Human chromosome-specific repetitive DNA sequences: novel markers for genetic analysis. Chiromosoma 95 : 375 (1987).

25. Nolte, M, Werner, M, von Wasielewski, $\mathrm{A}$, Nielgen, $G$, Wikens, L. and Georgii, A. Detection of numerical karyotype changes in the giant cells of Hodgkin's lymplhomas by a combination of FISH and immunohistochemistry applied to parafin sections. Histochem Cell Biol 105: 401 (1996).

26. Pahiplatz, M, de Wilde, P, Poddighe, $P$, van Dekken, H, Vooinjs, G and Hanselaar, A. A model for evaluation of in situ hybridization: Spot-count distributions in tissue sections. Cytometry 20: 193 (1995). Pinkel, D, Landegent, J, Collins, C. Fuscoe, J, Seagraves, $\mathrm{A}$, Lucas, J and Gray, J. Fluorescence. in situ hybridization with human chromosome-specific libraries: detection of trisomy 21 and translocations of chromosome 4. Proc Natl Acad Sci USA 85: 9138 (1988). 
and Grote. W. Cylogenetic findings and resuls of combined immunophenoyping and karyolyping in Hodgkin"s disease. Leukemia 8: 72 (1994).

29. Schouten, $H$, Sanger, W. Duggan, M, Weisenburger, D. MacLennan, Kand Armitage, J. Chromosomal abnomalities in Hodgkn's disease. Blood 73 . 2149 (1989).

30. Schutte, $B$, Feynders, M, Bosman, $F$ and Bliham, $G$. Flow cytometric detemination of DNA ploidy level in nuclei isolatted from paraftin-embedded tissue. Cytometry 6: 26 (1985).

3H. Speel. E, Jansen, $M$, Famaekers, F and Hopman, A. A novel triple-color detection procedure for brightifid micrascopy, combining in situ hybridization with immunocytochemistry. $J$ Histochem Cytochem 42: 1299 (1994).

32. Strehl, $S$ and Ambros, P. Flworescence in situ tybridization combined with immunohistochemistry for highly sensitive detection of chromosome 1 aberrations in neuroblastoma. Cytogenet Cell Genet 63: 24 (1993).

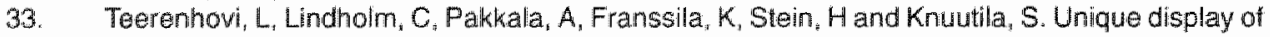
a pathologic karyotyjie in Hodgkin's disease by Reed-Sternberg cells. Cancer Genet Cytogenet $34: 305(1988)$.

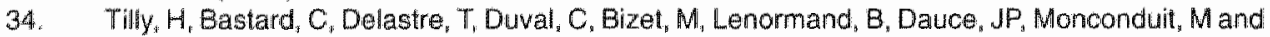
Piguet, H. Cytogenetic studies in untreated Hodgkin's disease. Blood $77: 1298$ (1991).

35. Waye, ll, Creeper, Land Willard, H. Organization and evolution of alpha satellite DNA from human chromosome 11. Chromosoma 95: 182 (1987).

36. Waye, England $S$ and Willard, $H$. Genomic organization of alpha satelite DNA on human chromasome 7: Evidence for two distinct altphoid domains on a single chromosome. Mol Cell Biol 7: $349(1987)$.

37. Waye, $\mathrm{J}$ and Willard, $\mathrm{H}$. Molecular analysis of deletion polymorphism in alpha satellite of human chromosome 17: Evidence for homologous unequal crossing-over and subsequent fixation. Nucleic Acid Res 14:6915 (1986).

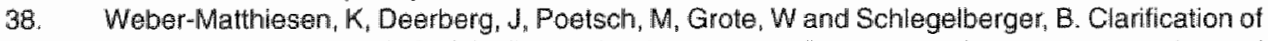
dubious karyotypes in Hodgkin's disease by simultaneous fluorescence immunophenotyping and interphase cytogenetics (FICTION). Cytogenet Cell Genet 70:243 (1995).

39. Weber-Matthiesen, $K$, Deerberg, J, Poetsch, M, Grote, Wand Schlegelberger, B. Numerical chromosome aberrations are present within the CD $30^{\circ}$ Hodigkin and Reed-Sternberg cells in $100 \%$ of analyzed cases of Hodgkin's disease. Blood 86: 1464 (1995).

40. Wolf, J, Kapp, U, Bohlen, H, Kornacker, M, Schoch, C, Stahl, B, Mucke, S, von Kalle, C, Fonatsch, C, Schaeter, H-E, Hansmann, M-L and Diehl, V. Periplzeral blood mononuclear cells of a patient with advanced Hodgkin's lymphoma give rise lo permamently growing Hodgkin-Reed Sternberg cells. Bllood 87: 3418 (1996). 


\section{Chapter 5}

\section{Morphologically normal, CD30 negative B-lymphocytes with chromosome aberrations in classical Hodgkin's disease: The progenitor cell of the malignant clone?}

Maurice PHM Jansen, Anton HN Hopman, Fredrik J Bot, Annick Haesevoets, Marian JPL Stevens-Kroef, Jan Willem Arends, Andrea Jox, Jürgen Wolf, Frans CS Ramaekers, and Harry C Schouten 


\section{Abstract}

In a recent study (Jansen et al., J. Pathol. 185: 145-153, 1998) we observed that numerical chromosome abnomalities in Hodgkin's disease are not restricted to the Hodgkin/ReedStemberg cells, but also occur in a fraction of morphologically normal cells. However, the phenotypic constitution of these genetically abnormal, morphologically nomal cells and their relationship with the Hodgkin/Reed-Stemberg cells could not be established in these earlier cases, because of the low frequency of these cells.

In the present study we investigated two cases of classical Hodgkin's disease containing a relatively large population of such apparently normal cells with aberrant chromosome copy numbers. Their phenotype and position within the developmental route of the malignant compartment were examined by using a combined in situ hybridization and immunocytochemistry approach. Numerical abnormalities for chromosome 1 in one case and for chromosomes $X, Y$ and 1 in the other case were not only observed in CD30 positive Hodgkin/Reed-Sterrberg cells, but also in CD30 negative, morphologically normal cells. It was shown that these genetically aberrant cells express the CD19 antigen, thus confirming their $\mathrm{B}$-cell nature. Our studies indicate a relationship between the genomic aberrations in these genetically abnormal , morphologically nomal B-cells and the Hodgkin/ReedSternberg cells, suggesting that they are progenitor cells of the malignant cell fraction.

\section{Introduction}

Studies on the cell biology of Hodgkin's disease in general focus on the small population of Hodgkin/Reed-Sternberg cells in an attempt to clarify the origin of these tumor cells. Structural and numerical chromosome aberrations are observed in these cells using karyotyping and in situ hybridization procedures, but no specific chromosome abnormality could be found to characterize Hodgkin's disease ${ }^{[5,24-27,34]}$. Furthermore, $V_{H^{-}}$and $V_{L}$-gene rearrangement analysis of single cells has demonstrated that Hodgkin/Reed-Sternberg cells are monoclonal and have a B-cell phenotype ${ }^{111}$ 19. 19.21. 301. However, in cases of Hodgkin's disease cases analyzed by flow cytometry, the fraction of aneuploid cells was larger than that of the fraction Hodgkin/Reed-Sternberg cells ${ }^{|i|}$.

We recently described that chromosome abnormalities in Hodgkin's disease are not restricted to the Hodgkin/Reed-Sternberg cells ${ }^{\left[{ }^{13]}\right.}$. Small populations of morphologically normal cells in malignant lymph nodes were shown to exhibit numerical chromosome aberrations. Therefore, we concluded that the malignant cell population in Hodgkin's disease is not limited to Hodgkin/Reed-Sternberg cells, but also includes a subset of cells with a morphologically normal appearance.

However, the phenotype of these genetically aberrant but morphologically normal cells and their relationship to the malignant Hodgkin/Reed-Sternberg cells could not yet be determined because of their low frequency in the earlier cases examined.

In the present study we analyzed two cases of advanced Hodgkin's disease with high frequencies of genetically aberrant cells using a combined immunocytochemistry and in situ hybridization approach to correlate for the phenotypic (CD19, CD30) and genetic (chromosomes $1, X, Y$ ) characteristics. On basis of our results we propose a model for the development from progenitor cells to Hodgkin/Reed-Sternberg cells. 


\section{Materials \& Methods}

Patient material

Case 1: In April 1994 tumor infiltration of the bone marrow was obsenved in a male patient (age 31) with mixed cellularity subtype Hodgkin's disease, which was orighinally diagnosed in 1991"A A cell line (L1236) could be established from atypical mononuclear lymphocytes of the peripheral blood of this patient [3e]. Paraffin sections ( 4 um thick) of the bone marrow specimen obtained for monitoring tumor progression at time of establishing the cell line were analyzed by combined immunocytochemistry and in situ hybridization.

Case 2: In December 1997 a male patient (age 68) was diagnosed with nodular sclerosing Hodgkin's disease. A fresh lymph node biopsy was used for routine pathological analysis and cytogenetic analysis. The pathological analysis included the CD20 and CD30 staining of the sections. For the cytogenetic analysis, cell suspensions obtained from this biopsy and from peripheral blood were cultured in RPMi11640 containing $15 \%$ fetal calf serum and $1 \%$ glutamin. Cultures were incubated in a $\mathrm{CO}_{2}$-incubator for 48 or 72 hrs when stimulated with pookweed or phytoheamatoglutin. Karyotyping was based on G-banding after trypsin-gilemsa staining.

\section{CD19 and CD30 immunocytochemistry}

Paraffin sections ( 4 um thick) from case 1 were brought onto Super Starfrost Plus glass slides (Menzel Glaesera, Braunschweig, Germany) and CD30 immunocytochemistry was performed according to the manufacturer's protocol (DAKO A/S, Glostrup, Denmark). The anti-CD30 antibody (BerH-2) was detected with biotim labeled horse anti-mouse IgG (Vector, Brunschwig Chemie, Amsterdam, The Netherlands) diluted $1: 200$, followed by avidin/ biotinylated peroxidase (Vector) both diluted 1:50. The sections wert then counterstained with haematoxylin and peroxidase activity was subsequently detected with 3,3,5,5'tetramethylbenzidine (TMB; Sigma, St. Louis, MO, USA) and $\mathrm{H}_{2} \mathrm{O}_{2}$ as described previously by Speel et al. ${ }^{[8,28]}$. Haematoxylin staining prior to the TMB reaction is required to improve the stability of TMB precipitate.

Cell suspensions from a fresh llymph node biopsy of case 2 were cytospinned for 5 min att 700 rpm onto Super Starfrost Plus glass slides (Menzel Glaeser(i⿱ $)$. These preparations as well as frozen sections (4 $4 \mathrm{~m}$ thick) were immunologically stained for CD 19 or CD30 (DAKO A/S) and subsequently pretreated for the in situ hybridization. The protocol for this combined procedure has been described by Weber-Matthiesen

\section{In situ hybridization}

A biotinylated DNA probe for the (peri)centromeric region of chromosome 1 (pUC1.77, $1.77 \mathrm{~kb}^{\text {(3) }}$ ) was prepared according to standard procedures ${ }^{[13]}$. This probe was a informative and reliable marker for general aneuploidy in several different malignancies $11.22,231$. Furthermore, directly fluorochrome labeled DNA probes for the (peri)centromeric regions of chromosomes 1, X (pBam X5,2.0kb ${ }^{1351)}$ and $Y(D Y Z 1,2.1 \mathrm{~kb}$; recognizing the long arm of $Y$ chromosome ${ }^{47}$ ) were prepared according to the supplier's instructions (Boehringer Mannheim, Mannheim, Germany). These DNA probes were labeled with FITC-11-d UTP (Boehringer Mannheim) or modamine-4-dUTP (Amersham, Buckinghamshire, UK).

The $4 \mu \mathrm{m}$ thick paraffin sections were pretreated with $85 \%$ formic acid $/ 0.3 \% \mathrm{H}_{2} \mathrm{O}_{2}(\mathrm{Merck}$, Darmstadt, Germany) for 20 minutes at room temperature, dehydrated with $70 \%$ ethanol/ $0.01 \mathrm{~N} \mathrm{HCl}$, treated with $1 \mathrm{M}$ sodium thiacyanate (Merck) at $80{ }^{\circ} \mathrm{C}$ for 10 minutes and di. 
gested with $4 \mathrm{mg} / \mathrm{ml}$ pepsin from porcine stomach mucosa $(2,500-3,500$ units per mg protein; Sigma) in $0.02 \mathrm{~N} \mathrm{HCl}$ at $37^{\circ} \mathrm{C}$ for 20 minutes ${ }^{[0]}$. Additionally, slides were dehydrated in $70 \%$ thanol/0.01 $\mathrm{N} \mathrm{HCl}$ and digested with $0.1 \%$ Carlsberg protease (Sigma protease XXIV, Sigma) in 0.1M TRIS. HCl pH7.5 and $0.05 \mathrm{M} \mathrm{NaCl}$ for 10 minutes at $3 \mathrm{~T}^{\circ} \mathrm{C}$ [3" and clehydrated again.

The pretreated paraffin sections were denaturated in a moist chamber for 5 minutes at 80 ${ }^{2} \mathrm{C}$. After overnight hybridization with the DNA probes (4 ng probe probe for chromosome 1 and $10 \mathrm{ng}$ probe for the other chromosomes) at $37^{\circ} \mathrm{C}$, sections were washed twice for 5 minutes in $2 \times 5 S \mathrm{C} / 0.05 \%$ Tween20 buffer $\mathrm{pH} 7.0$ at $42{ }^{\circ} \mathrm{C}$ and twice for 5 minutes in $4 \times 5 S C / 0.05 \%$ Tween20 buffer at room temperature. The ABC protocol (Vector) was applied for detection of the biotinylated probe in the procedure combining immunocytochemistry and in situ hybridization. Peroxidase activity was visualized by a diaminobenzidine (DAB; Sigma) precipitation reaction. Counterstaining was performed with haematoxylin and slides were dehydrated and mounted in Entellan (Merck).

Cytospins of the cell suspension from the fresh lymph node biopsy were denaturated in a moist chamber for 5 minutes at $75^{\circ} \mathrm{C}$, hybridized with directly fluorochrome labeled DNA probes overnight at $37^{\circ} \mathrm{C}$, and washed twice for 5 minutes in $2 \times S S C 10.05 \%$ Tween 20 buffer pH7.0 at $42{ }^{\circ} \mathrm{C}$, twice for 5 minutes in $0.1 \times S S C / 0.05 \%$ Tween20 buffer at $60^{\circ} \mathrm{C}$ and finally once for 5 minutes in $4 \times S S C / 0.05 \%$ Tween20 buffer at room temperature. Nuclei were counterstained with 4,6-diaminidino-2-phenylindole (DAPI; Sigma; $1.25 \mathrm{ng} / \mathrm{ml}$ ) diluted in glycerol containing 2.3\% 1,4-diazobicyclo-(2.2.2)-octane (DABCO; Sigma).

Combined immunocytochemistry and in situ hybridization on paraffin sections.

A protocol was established for the combination of immunocytochemistry and in situ hybridrization on paraffin sections for bright-field microscopical analyses.

CD30 reactivity was detected with a TMB precipitate reaction and recorded with a CCD S30 camera (Metasystems, Sandhausen, Germany) using the ISIS program of Metasystems (Sandhausen). $X$ - and $Y$-coordinates of CD30 positive and negative cells were determined and accessory images of an England-finder (Graticules Limited, Tonbridge, Kent, England) were recorded. Subsequently, the precipitate was dissolved in phosphate buffered saline (PBS) resulting in nuclei that were more accessible for the DNA probes used in the in situ hybridization protocol, that was applied as described above. The results of the in situ hybridization reaction were analyzed and recorded after reallocation of the cells on the slide using the $X$-and $Y$-coordinates and the England-finder images. The scoring criteria for the evaluation of the in situ hybridization results have been described earlier by Hopman et al. ${ }^{10.101}$. Finally, the results of CD30 immunocytochemistry and in situ hybridization were combined for the determination of the CD30 phenotype of the chromosomally abnormal cells.

Cell type evaluation.

The pathologists independently evaluated the chromosomally abnormal cell types using CD19 and CD30 staining and cell morphology. Hodgkin cells were defined in this evaluation as large $\mathrm{CD} 30$ positive cells with a large and distinct nucleolus. Reed-Sternberg cells on the other hand were defined as large CD30 positive bi- or multinucleated cells. Only areas with CD30 positive Hodgkin and Reed-Sternberg cells were evaluated in the sections. 


\section{Results}

Case 1

Immunocytochemistry and in situ hybridization procedures were combined on a paraffin embedded bone marrow biopsy in order to characterize the phenotype of chromosomally abnormal cells. Evaluation of the CD30 staining reaction in paraffin sections of this biopsy revealed that approximately $20 \%$ of the cells in this preparation were CD30 positive Hodgkin and Reed-Stemberg cells while the remaining compartment comprised CD30 negative bystander cells. About 300 cells could be evaluated for CD30 positivity or neglativity in combination with their chromosome 1 copy numbers (figure $1 \mathrm{a}-\mathrm{d}$ ). In approximately $10 \%$ of cells numerical chromosome 1 abnomalities were detected. One third of aneusomic nuclei clearly belonged to CD30 negative, morphologically nomal cells. Trisomy for chromosome 1 is mainly observed, although multiple copies for chromosome 1 were also detected, but were only seen in morphologically abnormal Hodgkin/Reed-Sternberg cells. More copies may be present but lost due to nuclear truncation in tissue sections. The largest population ( $\pm 66 \%$ ) of nuclei with an aberrant chromosome 1 copy number was observed in the CD30 positive Hodgkin and Reed-Stemberg cell population.

\section{Case 2}

The karyotype obtained from the fresh lymph node biopsy of this male patient fevealed about $10 \%$ of metaphase spreads with one extra copy for chromosome $X$, and no additional numerical or structural chromosome abmormalities. Peripheral blood lymphocytes showed a normal XY constitution.

In situ hybridization for chromosomes $X, Y$ and 1 was combined with immunocytochemistry for CD30 and CD19 to determine the phenotypic constitution of the chromosomally abnormal cells. This was performed on $4 \mu \mathrm{m}$ thick frozen sections and on a cell suspension obtained from the fresh lymph node biopsy (figure 1e-m). Of the one thousand cells that were analyzed a minority showed two copies for chromosome $X(3.5 \%)$, loss of the $Y$ chromosome $(3.0 \%)$, or an extra copy for chromosome $1(2.2 \%)$ (figure 1 e-g). Approximately half of the cells with an extra $X$ chromosome were CD30 negative and appeared morphologically normal. These genetically aberrant cells expressed CD 19 (figure $\| k \sim m$ ), whereas Hodgkin/Reed-Sternberg cells lacked CD19 and CD20. Furthermore, loss of the $Y$ chromosome was not limited to the CD30 positive Hodgkin/Reed-Stemberg cells. Again, approximately half of the genetically aberrant cells for the $Y$ chromosome were CD30 negative, and appeared morphologically normal. In addition, approximately one quarter of the cells with a gain in copy number for chromosome 1 was CD30 negative. Multiple-target fluorescence in situ hybtidization (figure $1 \mathrm{~h}$-j) showed that half of the genetically abnormal , morphologically nomal cells contained only a numerical abnormality for chromosome X (disomy), but not for chromosomes $Y$ or 1 , thus corresponding with the chromosomal constitution of the karyotyped cells. The other half of genetically aberrant cells contained $50 \%$ of cells with only a loss of the $Y$ chromosome and $50 \%$ of cells with a disomy for chiromosome $X$ and no $Y$ chromosome. CD30 negative morphologically normal cells with aberrant copy numbers for chromosome 1 were always seen with additional abnormalities for chromosomes $X$ or $Y$. Finally, all Hodgkin/Reed-Sternberg cells contained an extra copy of the $X$ chromosome, but had also lost the $Y$ chiromosome and contained an extra copy of chromosome 1 per nucleus. 


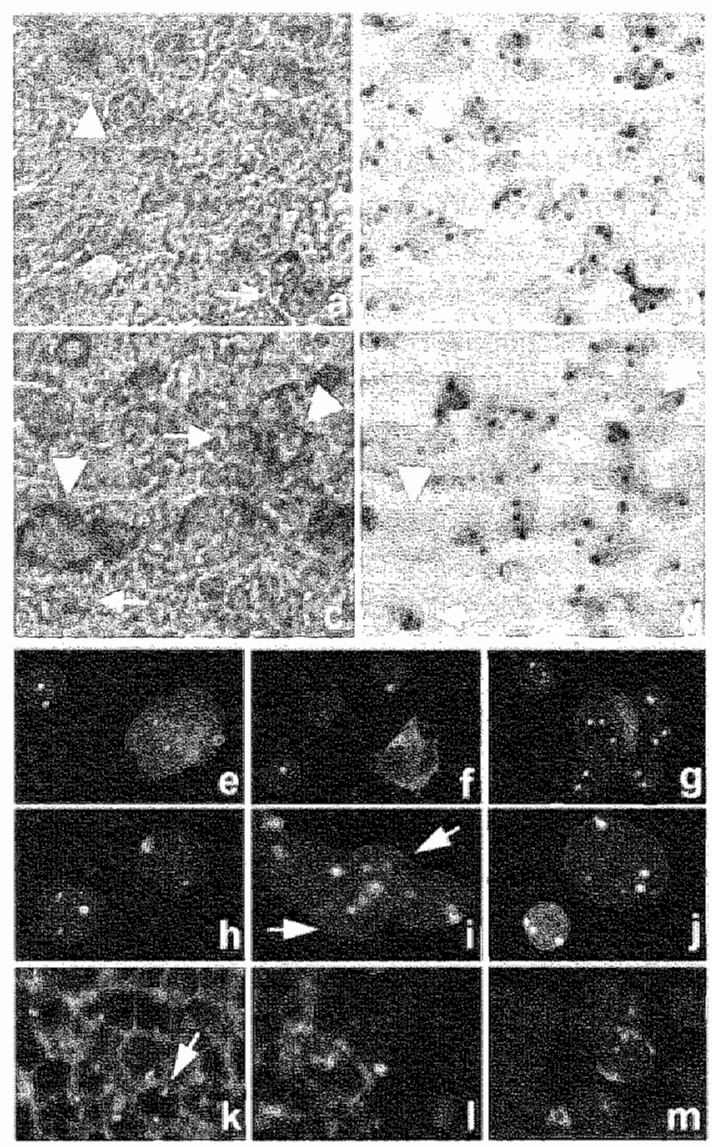

Figure 1. Paraffin sections of a bone marrow biopsy of Hodgkin's disease (case 1), analyzed for CD30 immunostaining $[a, c]$ and numerical aberrations for chromosome 1 with in situ hybridization $[b, d]$. It is demonstrated in corresponding that numerical chromosome aberrations are nol restricted to the CD30 positive Hodgkin/Fieed-Stemberg cells (arrowheads), but include also CD30 negative morphologically normal cells (arrows). Cell suspensions from the second case analyzed with the FICTION techmique $[\mathrm{e}-\mathrm{g}, \mathrm{k}-\mathrm{m}]$ or with multiple-target fluorescence in situ hybridization (FISH) [h-j]. CD30 positive Hodgkin/Reed-Sternberg cells (red staining reaction) and CDSo negative morphologically nomal cells (arrows) with numerical aberiations for chromosome $X$ (one extra copy) [e], Y chromosome (loss) [f], and chromosome 1 (one extra copy) [g]. Double-target FISH demonstrated numerical abnormalities for only chromosome X (two red signals) but not for the Ychromosome (one green signal) in a morphologically normal cell [h]. Numerical abnormalities for chromosome $X$ (wo red signals) and $Y$ (loss of green signal) were also observed in a morphologically normal cell [1]. Triple-target FISH showed numerical aberrations for chromosome $X$ (wwo red signals), $Y$ (loss of green signal), and 1 (three yellow signals) in a Hodgkin/ReedStemberg cell [j]. CD19 positive, morphologically normal cells (red staining reaction) with numerical aberrations for chromosome $X$ (one extra green signal) in a $B$-cell ricti area (arrow) $[\mathrm{k}]$, and an area with a low frequency of $\mathrm{B}$-Hymphocytes $[1, \mathrm{~m}]$. For colorf illustration see page 101. 
Figure 2 provides a schematic overview of the correlation between morphology. immunophenotypic and genetic characteristics of the individual cell types present in this case.

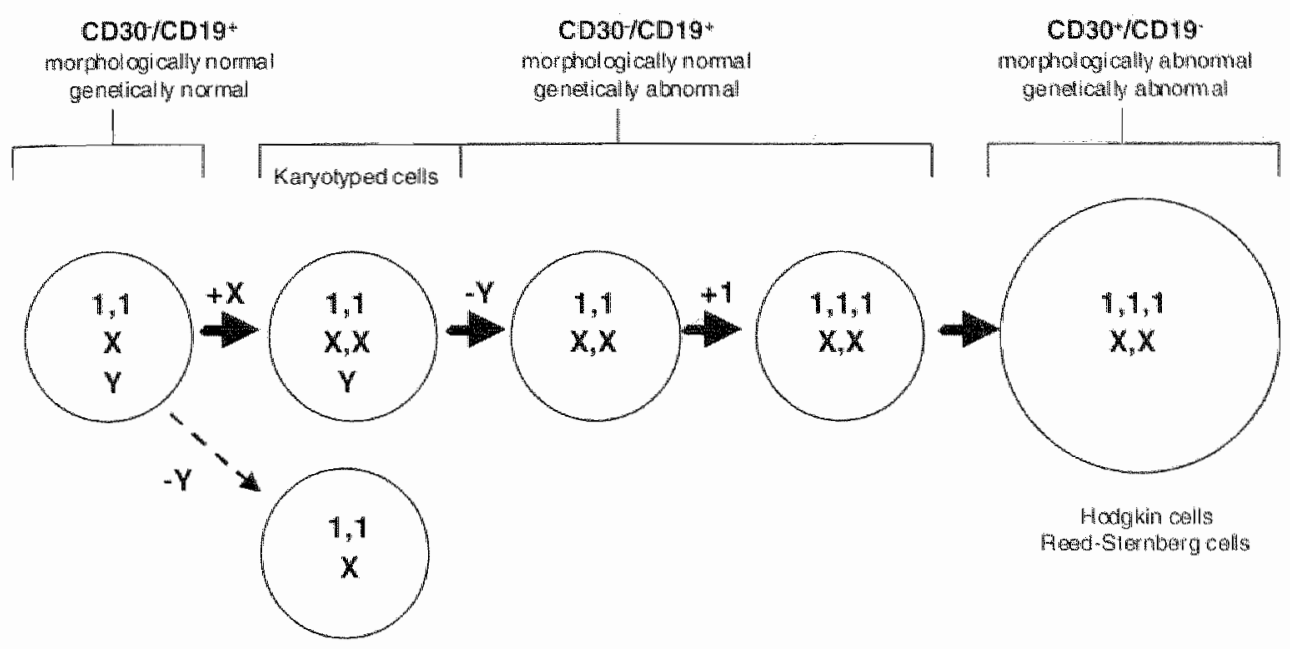

Figure 2. A model for tumor cell development in a male patient with classical Hodgkin's disease proposed on basis of results of the karyotyping and the combined immunocytochemical and in situ hybridization technique.

\section{Discussion}

In a recent study ${ }^{[13]}$ we observed that numerical chromosome abnormalities in Hodgkin"s disease are not restricted to Hodgkin/Reed-Sternberg cells, but are also detected in morphologically normal cells. The phenotypic constitution of these genetically aberrant "morphologically normal cells and their relationship to the Hodgkin/Reed-Sternberg cells could not however be investigated due to their low frequency. In this study tissue samples of two patients with classical Hodgkin's disease containing a relatively large population of chromosomally aberrant, but morphologically normal cells were used to determine their nature. Both cases showed numerical chromosome abnormalities in the CD30 positive Hodgkin/ Reed-Sternberg cell population. However, CD30 negative, morphologically normal cells with aberrant chromosome copy numbers were also observed. To circumvent false negative results due to CD30 staining heterogeneity, only areas with strong CD30 staining in the Hodgkin/Reed-Sternberg cells were evaluated. The CD30 negative, genetically abnormal cells did not exhibit a Hodgkin/Reed-Stermberg cell morphology. Taken together, these data demonstrate that CD30 negative, genetically aberrant, but morphologically nomal cells do exist in Hodgkin's disease.

The phenotypic and genetic constitution of the CD30 negative, morphologically normal cells and CD30 positive Hodgkin/Reed-Sternberg cells was further characterized in cell suspensions and frozen sections. Immunostaining for the B-cell antigen CD19 was observed in genetically abnormal, morphologically normal cells. As expected, the Hodgkinf Reed-Sternberg cells did not express the CD19 antigen, which is in accord with findings reported in literature ${ }^{[?, 17]}$. Recent studies have demonstrated that Hadgkin/Reed-Sternberg 
cells are derived trom B-Iymphocytes ${ }^{132}$. 15. 19.20.37.

The genotypic constitution was investigated in more detall to assess the relationship between the genetically aberrant, morphologicaly normal B-lymphocytes and the Hodgkinf Reed-Sternberg cells. Karyotyping revealed one extra copy for chromosome $X$ in cultured cells with no other numerical chromosome abnormalities. CD30 staining combined with single- and multiple-target in sifu hybridization revealed in single cell suspensions numerical abnormalities for chromosomes $Y$ and 1 , in addition to the disomy for chromosome $X$ in CD30 positive Hodgkin/Feed-Sternberg cells. Consequently, the karyotyped cells could not have originated from CD30 positive Hodgkin/Reed-Sternberg cells. Another study described similar results, i.e. the genetic constitution of CD30-positive Hodgkin/ReedStermberg cells did not correspond with the abnormal karyotype, because extra chromom some abnormalities in the malignant cells were observed with the in situ hybridization procedure ${ }^{[33}$.

In search for the cell of origin of the observed karyotype "morphologically normal cells were characterized by the combined immunocytochemistry and multiple target in situ hybridization procedure. It was demonstrated that several populations of CD 30 negative, morphologically normall cells with numerical abnomalities for chromosomes $X, Y$ or 1 existed, of which the largest fraction exhibited only one extra copy for chromasome $X$, with no abnormalities for chromosomes $Y$ and 1 . Therefore, these cells are the most likely to give rise to the observed abnormal karyotype. Furthermore, these cells expressed CD19 and are clonogenic, based on the observation that this karyotype was obtained from several divid. ing cells. Hence, these genetically aberrant, morphologically normal B-lymphocytes might be progenitor cells of the malignant Hodgkin/Reed-Sternberg cells, because they are genetically related to each other. Similarly, Weber-Matthiesen et al. [33] found a very small fraction of CD30 negative, morphologically normal cells which showed an identical genetic constitution when examined by in situ hybridization and by karyotyping but which could not be further analyzed. In the process of progression additional numerical chromosome abnomalities accumulated in the Hodgkin/Reed-Stemberg cell population.

A model for the development of Hodgkin/Reed-Sternberg cells from this progenitor cell can be described according to the phenotypic and genetic relationships mentioned above (figure 2). Phenotypically, the CD19-antigen is last during the tumor cell development whereas the CD30-antigen is acquired ${ }^{2 a}$. Genetically, the progenitor cells which had gained one extra copy for chromosome $X$, as seen in the karyotype and in the in situ hybridization procedure on cell suspensions, underwent a loss of the $Y$ chromosome and finally gained an extra copy for chromosome 1, resulting in the Hodgkin/Reed-Sternberg genotype. The population of cells with only a loss of the $Y$ chromosome was not observed in the karyotype, implying a growth disadvantage of this clone and thus this fraction did not contribute to the developmental route (figure 2) 229. How all these observations fit in the hypothesis of malignant transformation of the follicle center cells has to be assessed. It is postulated that tumor cell development starts with crippling mutations in germinal center cells from which a small population of mulated cells is rescued and transformed into Hodkgin/ReedSitemberg cells ${ }^{110.18}$. The chromosomal aberrations described above then develop easily in the malignant process.

Summarizing, immunocytochemistry combined with in situ hybridization marks a population of CD30 negative, morphologically normal B-lymphocytes with numerical chromosome abnormalities in Hodgkin's disease. Since these cells show aneusomy for several chro- 
mosomes, they have to be regarded as malignant cells. Furthermore, since these cells proliferate when brought in culture, they may be progenitors of the Hodgkin/Reed-Stemberg cell population, a conclusion also based on the observed genetic relationships.

\section{Acknowledgements:}

We thank Elena Martini for providing the directly labelled probes for chromosomes $1, X$ and $Y$. Furthermore, we are grateful to the Nijbakker-Mora Foundation and the Ank van Vlissingen Foundation for their financial support.

\section{References}

1. Atkin, N. Chromosome t aberrations in cancer. Cancer Genet Cyrogene $21: 279(1986)$.

2. Bai, $M$. Jiwa, $N$, Horstman, $A$, Vos, W, Kluin, P, Van-der-Valk, P. Mullink, H, Walboomers, $J$ and Meijer, C. Decreased expression of cellular markers in Epstein-Barr virus-positive Hodgkin's disease. J Pathol 174: 49 (1994).

3. Cooke, $H$ and Hindley, J. Cloning of human satellite III DNA: different components are on different chromosomes. Nucleic Aaids Res6: 3177 (1979).

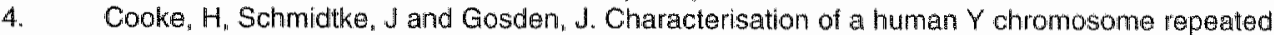
sequence and related sequences in thigher primates. Chromosoma 87: 491 (1982).

5. Deerberg Wittram, J, Weber-Matthiesen, K and Schlegelberger, B. Cytogenetics and molecular cytogenetics in Hodgkin's disease. Ann Oncol7 (Sup 4): 49 (1996).

6. Erdkamp, F, Schouten, H, Breed, W, Janssen, W. Hoffmann, J, Schutte, B and Blijham, G. DNA aneuploidy in Hodgkin's disease: a multiparameter flow cytometric analysis. Leuk Lymphoma 12 : 297 (1994).

7. Haluska, F, Birufsky, A and Canellos, $\mathrm{G}$. The cellular biology of the Reed-Sterntberg cell. Blood 34 : $1005(1994)$.

8. Hopman, $\mathrm{A}_{0}$ Claessen, $\mathrm{S}$ and Speel, E. Multi-colouir brightfield in situ hybridisation on tissue sections. Histochem-Cell-Biol 108: 291 (1997).

9. Hopman, A, Podidighe, P. Smeets, A, Moesker, O, Beck, J, Vooijs, G and Pamaekers, F. Detection of numerical chromosome aberrations in bladder canceir by in situ hybridization. Am $J$ Pathol 135: $1105(1989)$.

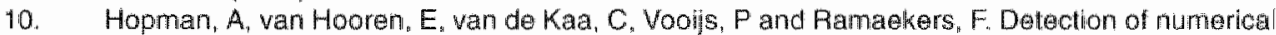
chromosome aberrations using in situ hybridization in paraffin sections of routhely processed bladder cancers. Mod Parthol 4: 503 (1991).

11. Hummen, M, Marafiot!, T, Ziemann, Kand Stein, H. Ig rearrangements in isolated Reed-Stemberg cells: conclusions from four different studies. Ann Oncol 7 (Sup 4): 34 (1996).

12. Hummel, M, Ziemann, $K$, Lammert, H, Pileri, S, Sabattini, E and Stein, H. Hodgkin's disease with unonoclonal and polyclonal populations of Feed-Sternberg cells. N Engl J Med 333: 901 (1995).

13. Jansen, M. Hopman, A. Haesevoets, A, Gennolte, II, Bot, F. Arends, d, Ramaekers, F and Schoutten, H. Chromosomal abnormalities in Hodgkin's disease are not restnicted to Hodghin/Reed-Sternberg cells. I Pathol 185: 145 (1998).

14. Jox, A, Zander, T, Dielh, V and Wolf, J. Clonal relapse in Hodgkin's disease. N Engl J Med337: $499(1997)$.

15. Kanzler, H, Hansmann, M-L, Kapp, U, Wolt, J, Diehl, V, Rajewsky, Kand Küppers, R. Molecular single cell analysis demonstrates the derivation of a peripheral blood-derived cell line (L1236) from the Hodgkin/Reed-Sternberg cells of a Hodgkin's lymphoma patient. Blood87: 3429 (1996).

16. Kanzler, $H$, Küppers, $R$, Hansmann, $M-L$ and Rajewsiky, K. Hodgkin and Feed-Sternbergl cells in Hodgkin's disease represent the outgrowth of a dominant tumor clone derved from (crippled) germinal center B cells. J Exp Med 184: 9495 (1996).

17. Koduru, P, Susin, M, Schuman, P, Catell, D, Goh, JC, Karp, L and Broome, J. Phenotypic and genotypic characterization of Hodgkin's disease. Am i Hematof 44: 117 (1993).

18. Küppers, R and Rajewsky, K. The origin of Hodgkin and ReedSternberg cells in Hodgkin's dis. 
ease. Arinu Fev immunol 16: 471 (1998).

19. Kuppers, $A$, Fajewsky, $K$, Zhao, $M$, Simons, $G$, Laumann, $R$, Fischer, $F$ and Hansmann, M-L. Hodgkin's disease: clonal lg gene rearrangements in Hodgkin and Reed-Stemberg cels picked from histological sections. Ann N Y Acad Sci 764: 523 (1995).

20. Leoncini, L. Spina, D, Megha, T, Galorini, M, Tosi, P. Hummel, M, Stein, H, Piler, S, Kraft, R, Laissue, J and Cottier, H. Cell kinetics, morphology, and molecular IgVH gene rearrangements in Hodgkin's disease. Leuk Lymphoma 26: 307 (1997).

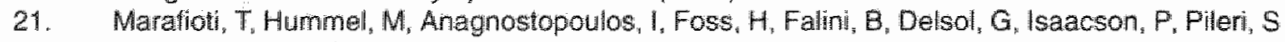
and Stein, H. Origin of nodular lymphocyte-predominant Hodgkin's disease from a clonal expansion of highly mutated germinal-center B cells. N Engl J Med 337: 453 (1997).

22. Mertens, $F$, Johansson, $B$, Hoglund, Mand Mitelman, F. Chromosomal imbalance maps of malignant solid tumors: a cytogenetic survey of 3185 neoplasms. Cancer Fes $57: 2765$ (1997).

23. Miteiman, $F$, wohansson, $B$, Mandahl, $N$ and Mertens, F. Clinical significance of cytogenetic findings in solid tumors. Cancer Genet Cytogenet 95: 1 (1997).

24. Noite, Marner, M, von Wasielewski, $\mathrm{R}$, Nietgen, $\mathrm{G}$, Wilkens, L and Georgii, A. Detection of numerical karyotype changes in the giant cells of Hodgkin's lymphomas by a combination of FiSH and immunohistochemistry applied to paraftin sections. Histochem Cell Biol 105: 401 (1996).

25. Pringle,, shaw, d, Gillies, A and Lauder, I. Numerical chromosomal aberrations in Hodgkin's disease detected by in situ hybridisation on routine paraffin sections. J Clin Patho/ 50: 553 (1997).

26. Schlegelberger, B, Weber-Matthiesen, K, Himmler, A, Bartels, H, Sonnen, R, Kuse, $R$, Feller, A and Grote. W. Cytogenetic findings and results of combined mmunophenotyping and karyotyping in Hodgkin's disease. Lewkemia 8: 72 (1994).

27. Schouten, H, Sanger, W, Duggan, M, Weisenburger, D, MacLennan, Kand Armitage, d. Chromosomal abnormalities in Hodgkin's disease. Bload73: 21,49(1989).

28. Speel, E, Jansen, M, Flamaekers, F and Hopman, A. A novel triple-color detection procedure fior brightfield microscopy, combining in situ hybridization with immunocytochemistry. I Histochem Cytochem 42: 1299 (1994).

29. Stone, J and Sandberg, A. Sex chromosome aneuploidy and aging. Mutat Res 338: 107 (1995).

30. Tamaru, J, Hummel, M, Zemlin, M, Kalwelage, B and Stein, H. Hodgkin's disease with a B-cell phenotype often shows a VDJ rearrangement and somatic multations in the VH genes. Bload 84 : $708(1994)$.

31. Wang, N, Pan, $Y$, Heiden, $T$ and Tribukailt. B. Improved method for release of cell nuclei from paraftin-embedded cell material of squamous cell carcinomas. Cytometry 14:931 (1993).

32. Weber-Matthiesen, K, Deerberg, J, Muller Hermelink, A, Schllegelberger, B and Grote, W. Rapid immunophenotypic characterization of chromosomally aberrant cells by the new FICTION method. Cytogenet Cell Genet63: $123(1993)$.

33. Weber-Matthiesen, K, Deerberg. J, Poetsch, M, Grote, W and Schlegelberger, B. Claritication of dubious karyotypes in Hodgkin's disease by simultaneous fluorescence immunophenotyping and interphase cytogenetics (FICTION). Cytogener Cell Genet 70: 243 (1995).

34. Weber-Matthiesen, $K$, Deerberg, J, Poetsch, M, Grote, W and Schlegelberger, B. Numerical chromos ome aberations are presenl within the $\mathrm{CD} 30+$ Hodgkin and Reed-Stemberg cells in $100 \%$ of analyzed cases of Hodgkin's disease. Blood 86: 1464 (1995).

35. Willard, H, Smith, Kand Sutherland, J. Isolation and characterisation of a major fandem repeat family from the human X chromosome. Nucleic Acids Res 19:3237 (1983).

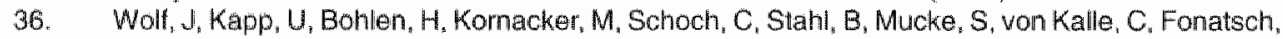
C. Schaefer, HE, Hansmann, M-L and Dieh, W. Peripheral blood mononuclear cells of a patient with advanced Hodgkin"s lymphoma give rise to permariently growing Hodgkin-Reed Sternberg cells, Blood 87: 3418 (1996).

37. Yatabe, Y, Oka, $K$, Asai, J and Mori, N. Poor correlation between clonal immunoglobulin gene rearrangement and immunoglobulin gene transcription in Hodgkin's disease. Am J Pathol 49 : 1351 (1996). 


\section{Chapter 6}

Genotyping and phenotyping of distinct cell populations in the Hodgkin-derived cell line L1236 provides evidence for progressive in vitro differentiation of precursor cells into Hodgkin/Reed-Sternberg-like cells.

Maurice PHM Jansen, Anton HN Hopman, Fredrik J Bot, Annick Haesevoets, Frans CS Ramaekers, and Harry $\mathrm{C}$ Schouten 


\section{Abstract}

The phenotypic and genetic constitution of morphologically distinct cell populations in the Hodgkin-derived cell line L1236 was established and compared to the characteristics of the cells in the tumor from which the cell line has originated.

Three major cell populations can be distinguished in the culture on basis of cell morphology and nuclear size, i.e. small mononucleated cells, larger mononucleated cells, and large multinucleated cells. The latter two cell populations morphologically resemble the Hodgkin/ Reed.Sternberg cells detected in the tumor. The CD30 make up of these different cell populations differs slightly but all in all only one quarter of the total cell culture was found to express the CD30 antigen. To establish the proliferative versus differentiated status of the individual cell populations, Ki-67-antigen and A-type lamin expression patterns were immunocytochemically determined.

The Ki-67 antigen was detected in the majority of cells in an exponentially growing culture, whereas onlly half of the cells in a nutritionally deprived culture expressed the Ki-67 antigen. No differences in expression between small and large cells were observed for this antigen. A-type lamins were expressed to a limited extent $( \pm 20 \%)$ in the three cell types of an exponentially growing culture. However, in a nutritionally deprived culture A-type lamin expression increased dramatically in the large cells but was maintained at the same level in the small cells. This suggests that large cells attain a more differentiated phenotype than small celis, despite the fact that both cell types retain the ability to prolliferate.

For the genetic constitution, copy numbers for chromosomes 1,9 , and 11 were determined in the bone marrow infilltrate of the primary Hodgkin tumor, as well as in the cell line. Morphologically distinguishable Hodgkin cells and a small population of CD30 negative morphologically normal cells (precursors) in the tumor had a trisomy for chromosome 1. Trisomies for chromosome 11, and less frequently for chromosome 9 , were also observed in the tumor. Furthermore, some large cells in the tumor had multiple copies for the investigated chromosomes.

The major fraction of small cells in the cell line had a trisomy for chromosomes 1 and 11 , whereas there was a disomy for chromosome 9. Large Hodgkin and Reed-Sternberg-like cells had multiple copies for chromosomes 1,9 , and 11 , showing that endoreduplication does occur in these cells. Furthermore, the nuclei of multinucleated cells differed in chromosome 1 constitution, indicating that multinucleated cell development does not evolve via cell fusion but via endoreduplication and chromosome instability. The lack of CD30 staining in the majority of cells in the cell line, suggests that the cell line originates from the genetically aberrant, CD30 negative, morphologically normal cells in the tumor. The population of small CD3o negative cells in the cell line could be shown to have on the one hand proliferative potential and on the other hand the ability to differentiate into Hodgkin-like and Reed-Sternberg-like cells.

\section{Introduction}

In a recent study we have characterized a potential progenitor cell type for Hodgkin's disease ${ }^{\left.1{ }^{13}\right]}$. This morphologically normal, but genetically aberrant B-cell type is CD30 negative and not terminally differentiated (see chapter 5). From one of the cases of Hodgkin's disease that contained a small, but distinct fraction of these precursor cells in the bone marrow infiltrate of the primary tumor (see chapter 5), a cell line (L1236) was derived by culturing blood samples taken from the patient ${ }^{30 !}$.

In the present study we used this cell line as a model system in an attempt to obtain further proof for the existence of the precursor cell of Hodgkin's disease. Similarly to the situation 
tions, which could be distinguished on basis of morphology and nuclear size. Like the Hodgkin cells and Reed-Sternberg cells in vivo, large mononucleated and multinucleated cells were seen in vitro. The different cell populations in the cell line were, therefore, characterized separately for their phenotypic and genetic constitution and compared to the results obtained with the patient's tumor.

In an earlier study immunoglobulin gene rearrangements were observed, indicating that the cell line originated from B-lymphocytes, but when the cell line was phenotypically characterized for $\mathrm{B}$ - and T-cell antigens, a lack of these antigens was seen in all cells ${ }^{[30 \mid}$. The immunoglobulin gene rearrangements were also determined in the Hodgkin/ReedSternberg cells of the primary tumor and found to be identical with those in the cell line ${ }^{[16 !}$. Furthermore, the cell line exhibits a near-triploid karyotype, revealing abnormal copy numbers for most chromosomes ${ }^{[30]}$. The aberrant chromosome copy numbers in the cell line were, however, not analyzed in the different cell populations of the culture.

Therefore, chromosome copy numbers of small cells, large cells and multinucleated cells were determined separately using the in situ hybridization technique. Furthermore, the chromosome content and CD30 constitution of the different cell populations in the cell line was established simultaneously, to allow a further characterization. Comparison with the in vivo situation, where CD30 negative morphologically normal cells were found to exhibit genomic aberrations, appeared feasible (see chapter 5).

For a further characterization of the different cell populations, with the major goal of establishing their proliferative capacity versus differentiated phenotype, we applied antibodies to the $\mathrm{Ki}-67$ antigen and A-type lamins, respectively. In general it is accepted that A-type lamins are expressed in well-differentiated cells and tissues and are absent in highly proliferating and/or poorly differentiated cells $[4,6,7,9,19,23]$. Furthermore, in Hodgkin's disease it was observed that the Hodgkin/Reed-Sternberg cells expressed A-type lamins, whereas this lamin subtype was lacking in proliferating follicle center cells of the reactive lymph node ${ }^{[14]}$.

These studies provide further evidence for the existence of a CD30 negative, chromosomally aberrant tumor cell population in the Hodgkin-derived cell line, derived from a precursor cell population present in the tumor. This cell population has maintained the capacity to differentiate into larger, (CD30 positive) cells and to form multinucleated cells.

\section{Materials And Methods}

\section{Patient material}

Tumor infiltration of the bone marrow was observed three years after the initial diagnosis in a male patient (age 31) with mixed cellularity subtype Hodgkin's disease [15]. Paraffin sections ( $4 \mu \mathrm{m}$ thick) of the bone marrow specimen obtained for monitoring tumor progression could be analyzed by the situ hybridization technique.

\section{Cell line}

A cell line (L1236) could be established from atypical mononuclear lymphocytes of the peripheral blood of this patient ${ }^{[30]}$. This cell line was grown in RPMI 1640 medium containing $10 \%$ heat inactivated foetal calf serum (FCS), $50 \mu \mathrm{g} / \mathrm{ml}$ gentamicin, and $2 \mathrm{mmo} / / \mathrm{L}$-glutamine in a $5 \% \mathrm{CO}_{2}$ atmosphere at $37^{\circ} \mathrm{C}$. Furthermore, two different culture experiments were applied. The first set of experiments used an exponentially growing culture, obtained by renewal of the culture medium every other day. The second set of experiments used a nutritionally deprived culture, obtained after a four day renewal of the culture medium. 


\section{Antibodies used in this study}

Mouse monoclonal antibodies against A- and B-type lamins were used for immunocytochemical analyses. The monoclonal antibody $133 \mathrm{~A} 2$ (IgG3) against lamin $\mathrm{A}$ was kindly provided by Dr. Y. Raymond (Montreal, Quebec, Canada), and diluted 1:1000 112! Antibody $41 \mathrm{CC} 4(\mathrm{lgM})$ against lamin $\mathrm{A} / \mathrm{C}$ and kindly provided by Dr. G. Warren (Heidelberg, Germany), reacts more strongly with the lamin $C$ isoform than with lamin $A$, and was used

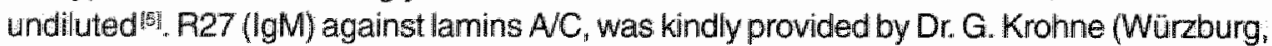
Germany), and was used undiluted [31!. The monoclonal antibody X223 (tgG1) against lamin $\mathrm{B2}$, also a gift from Dr. G. Krohne, was diluted 1:100"10. Antibody 101B7.2 (lgG1) against lamin B2 (Matritech Inc., Cambridge, MA), was diluted 1:100. LN43 (IgG1) against lamin B2, was kindly provided by Dr. E.B. Lane (Dundee, UK) and was used undiluted [a! . The monocional antibody 119D5 (lgG1) against lamin B1, was a gift from Dr. Y. Raymond, and was diluted 1:750.

Furthermore, Anti-CD30 (Ber-H2 clone; DAKO A/S, Glostrup, Denmark), a mouse monoclonall $\lg$ G1, diluted 1:25, was used for the detection of Hodgkin/Reed-Sternberg cells ${ }^{120}$. 21]. Finally, a rabbit polyclonal antiserum recognizing the proliferation marker Ki-67 (DAKO

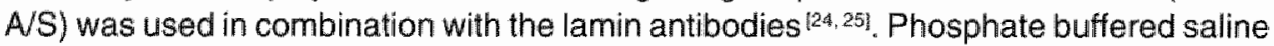
(PBS) pH 7.0 withoult primary antibodies were used as a negative control.

Several conjugated secondary antibodies were used for the detection of antibody binding in the immunofluorescence analyses. Fluorescein isothiocyanate (FITC) conjugated swine anti rabbit (DAKO A/S), was used for the detection of anti-Ki-67 and diluted 1:100. Biotin labeled horse anti mouse (DAKO A/S), diluted 1:200, was combined with FITC or Texas Red conjugated avidin (Vector, Brunschwig Chemie, Amsterdam, The Netherlands), both diluted 1:100, for the detection of all lamin antibodies and anti-CD30.

\section{Sample preparation}

Samples from the cell line were cytospinned for 5 minutes at 1200 rpm onto Super Starfrost Plus slides (Menzel Glaeser ${ }^{\text {t }}$, Braunschweig, Germany) and air dried at room temperature for 1 hour. For the immunocytochemical procedure, slides were fixed in $100 \%$ methanol for 1 minute before applying primary antibodies.

For the in situ hybridization procedure, cytospinned samples from the cell line were pretreated with $0.1 \mathrm{mg} / \mathrm{ml}$ pepsin from porcine stomach mucosa $(2,500-3,500$ units per $\mathrm{mg}$ protein; Sigma) in $0.01 \mathrm{~N} \mathrm{HCl}$ at $37^{\circ} \mathrm{C}$ for 20 minutes, or pre-treated according to the FICTION procedure whenever combined with CD30 immunocytochemical staining procedure ${ }^{228}, 2$. Paraffin sections ( $4 \mu \mathrm{m}$ thick) from the bone marrow biopsy were treated with $85 \%$ formic acid $/ 0.3 \% \mathrm{H}_{2} \mathrm{O}_{2}$ (Merck, Darmstadt, Germany) for 20 minutes at room temperature. After dehydration with $70 \%$ ethanol $/ 0.01 \mathrm{~N} \mathrm{HCl}$, the sections were treated with $1 \mathrm{M}$ sodium thiocyanate (Merck) at $80^{\circ} \mathrm{C}$ for 10 minutes and digested with $4 \mathrm{mg} / \mathrm{ml}$ pepsin from porcine stomach mucosa (2,500-3,500 units per mg protein; Sigma) in $0.02 \mathrm{~N} \mathrm{HCl}$ at $37^{\circ} \mathrm{C}$ for 20 minutes ${ }^{111}$. Additionally, slides were dehydrated in $70 \%$ ethanol/0.01 $\mathrm{N} \mathrm{HCl}$ and digested with $0.1 \%$ Carlsberg protease (Sigma protease XXIV, Sigma) in $0.1 \mathrm{M}$ TRIS.HCl pH7.5 and $0.05 \mathrm{M} \mathrm{NaCl}$ for 10 minutes at $37^{\circ} \mathrm{C}$, and dehydrated again [26].

\section{Immunofiturescence procedure}

For a singlle antigen analysis the slides were incubated with antibodies against a lamin subtype, Ki-67 or CD30 antigen for 30 minutes at $37^{\circ} \mathrm{C}$. For the combined detection of two antigens, the slides were incubated with mouse monoclonal antibodies against the Atype lamins simultaneously with the polyclonal antibody against the Ki-67 antigen, also for 30 minutes at $37^{\circ} \mathrm{C}$. The $\mathrm{Ki}-67$ antigen was stained with FITC conjugated swine anti 
rabbit Ig. The lamins were detected with biotin labeled horse anti mouse Ig and Texas Red conjugated avidin. For the combination of the in situ hybridization procedure with immunom cytochemistry, CD30-antigen was detected with horse radish peroxidase labeled rabbit anti mouse Ig and horse radish peroxidase labeled swine anti rabbit lg. Peroxidase activity was visualized by the catalyzed reporter deposition (CARD) system. (NEN Life Sciences, Boston, MA, USA), amplifying the signal by deposition of fluorochrome-labeled tyramide molecules ${ }^{[1.2 .22]}$. After each incubation step, slides were washed with PBS at room temperature. Slides were dehydrated and nuclei were counterstained with 4;,6-diamidino-2-phenylindole (DAPl; Sigma; $1.25 \mathrm{ng} / \mathrm{mll}$ ) in 90\% glycerol, $0.02 \% \mathrm{NaN3}, 10 \%$ $0.2 \mathrm{M}$ Tris-HCl (pH8.0), and 2.0\% 1,4-diazobicyclo-(2.2.2)-octane (DABCO; Sigma) (pH8.0), to reduce photobleaching. Control incubations included omission of the primary antibodles and incubation with all secondary antibodies. The staining reactions were analyzed with a Leica DM fluorescence microscope and recorded with a CCD S30 camera (Metasystems, Sandhausen, Germany).

\section{In situ hybridization procedure}

Probes used for the in situ hybridization analysis hybridize to the (peri)centromeric regions of human chromosomes 1 (pUC1.77, $1.77 \mathrm{~kb}^{[8]}$ ), 9 (pHUR98, $0.16 \mathrm{~kb} \mathrm{p}^{117}$ ), and 11 $\left(\mathrm{PLC}_{11 \mathrm{~A}}, 0.85 \mathrm{~kb}^{[27}\right)$. These DNA probes were dissolved in hybridization buffer, containing $60 \%$ formamide, $2 \times S S C \mathrm{pH} 7.0,10 \%$ dextran sulphate, $0.2 \mathrm{mg} / \mathrm{m} /$ herring sperm DNA and yeast tRNA as carrier DNA and RiNA, respectively. The final probe concentration was $0.4 \mathrm{ng} / \mathrm{ml}$ for pUC1.77 and $1 \mathrm{ng} / \mathrm{m} /$ for the other autosomal probes. Ten microliters of hybridization mixture were added to the slides under a coverslip. Samples were then denaturated in a moist chamber at $75^{\circ} \mathrm{C}$ for 3 minutes. Hybridization was allowed overnight at $37^{\circ} \mathrm{C}$. Samples were washed twice for 5 minutes in $2 \times \mathrm{SSC} / 0.05 \%$ Tween20 buffer $\mathrm{pH} 7.0$, at $42^{\circ} \mathrm{C}$, twice for 5 minutes in $0.01 \times \mathrm{SSC} / 0.05 \%$ Tween 20 buffer $\mathrm{pH} 7.0$, at $60^{\circ} \mathrm{C}$, and once in $4 \times S S C / 0.05 \%$ Tween 20 buffer for 5 minutes at room temperature. The biotinylated probes were detected according to the procedure of Pinkel et al, ${ }^{[16]}$, in subsequent incubations with fluorescein isothiocyanate (FITC) conjugated avidin (AvFITC; Vector, Brunschwig Chemie, Amsterdam, The Netherlands), biotin-conjugated goat anti-avidin (BioGaA; Vector) and again FITC-conjugated avidin, all for 20 minutes at $37^{\circ} \mathrm{C}$ in a 1:100 dilution. Nuclei were counterstained with 4-,6-diaminidino-2-phenylindole (DAPI; Sigma; $1.25 \mathrm{ng} / \mathrm{ml})$, diluted in glycerol containing $2.3 \% 1,4$-diazobicyclo-(2.2.2.)-octane (DABCO; Sigma).

\section{Data evaluation}

The ISIS program of Metasystems (Sandhausen, Germany) was used to measure the surface area of the recorded nuclei. The average nuclear surtace area plus one time the standard deviation was used as a threshold to distinguish small cells from large cells.

\section{Results}

Phenotyping of the different cell populations

The average nuclear surface area of the different cell populations in the tumor ranged from $35 \mu \mathrm{m}^{2} \pm 10 \mu \mathrm{m}^{2}$ (median $=40 \mu \mathrm{m}^{2} ; \mathrm{n}=219$ ) for sinall, morphologically normal, cells to $105 \mu \mathrm{m}^{2} \pm 45 \mu^{2}$ (median $=95 \mu \mathrm{m}^{2} ; n=97$ ) for large Hodgkin/Reed-Sternberg cells. In the cell line, the average nuclear surface area ranged from $45 \mu \mathrm{m}^{2} \pm 13 \mu \mathrm{m}^{2}$ (median $=42$ $\mu \mathrm{m}^{2} ; n=206$ ) for small cells to $107 \mu \mathrm{m}^{2} \pm 33 \mu \mathrm{m}^{2}$ (median $=94 \mu \mathrm{m}^{2} ; \mathrm{n}=22$ ) for large Hodgkin/Reed-Stemberg-like cells in the cell line. Cell line L1236 was immunocytochemi 

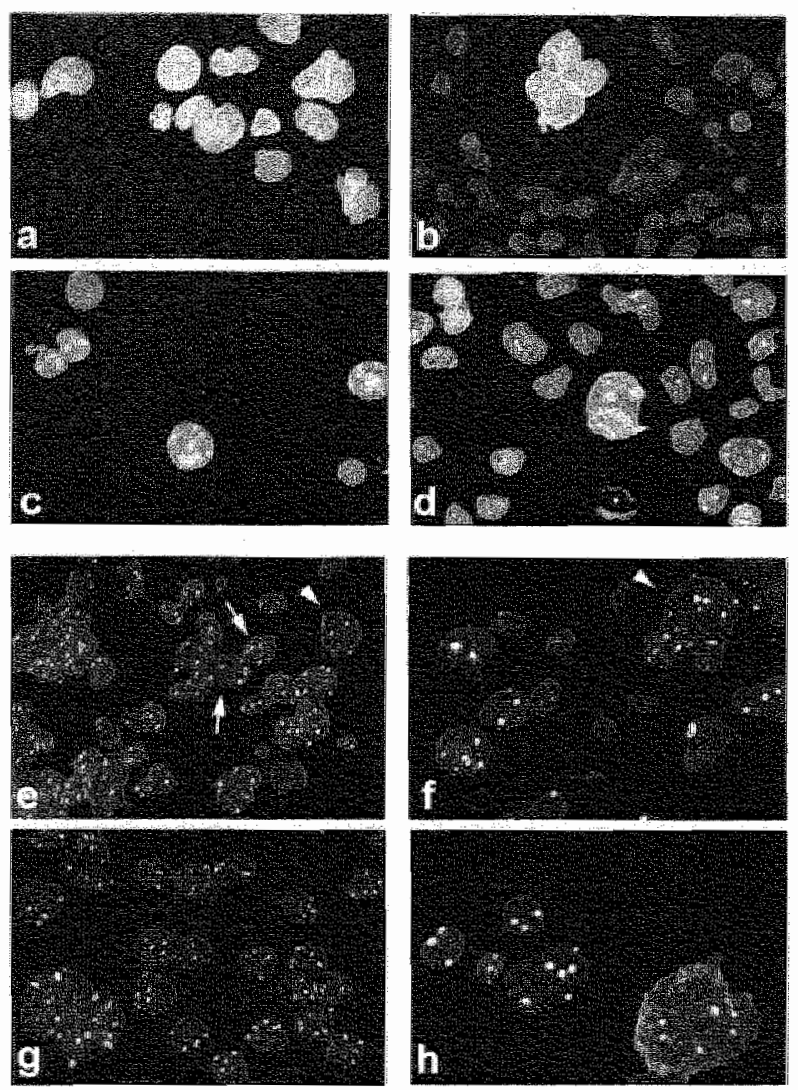

Figure 1. The phenotypic and genetic constitution determined on cytaspins of the Hodgkin-derived cell line L1236 $[\mathrm{a}-\mathrm{d}, \mathrm{g}, \mathrm{h}]$ and on paraffin sections from the bone marrow infiltrate of the Hodgkin tumor [e,f]. All figures were recorded at a $400 \times$ magnification and thereatter processed. [a] Lamin B2 expression as detected with the LN43 antibody, showing that most cells were lamin B2 positive. [b] Lamin AVC expression as detected with the R27 antibody, demonstrating the strong positivity of the large Hodgkin/Reed-Sternberg-like cells. [c] Ki-67 antigen detection with the polyclonal antibody shows both positive as well as negative cells. [d] Combined lamin $A / C$ and Ki-67 antigen immunophenotyping demonstrating Hodgkin/Peed-Sternberg-like cells with lamin $A / C$ (red) and Ki-67 (green) prositivity and small cells with only K 16 . and/or lamin AC positivity. [e] Numerical abnormalities for chromosomes 1 (green) and 9 (red) as detected with in situ hybridization in morphologically nomal cells (arrows) and in Hodgkin/ReedSternberg cells (arrowhead) of the primary tumor. [1] A Hodgkin/ReedSternberg cell (arrow) of the primary tumor with a polysomy for chromom. somes 1 (green) and 9 (red). [g] Chromosome 1 (green) and 9 (red) constitution of the Hodgkin-derived cell line shows predominant?y a trisomy for chromosome $f$ and a disomy for chromosome 9. Furthermore, a large multinucieated Reed-Sternberg-like cell with a high copy number for chromosomes 1 and 9 . [h] CD30 immunophenotyping showing a CD30 negative Hodgkin-like cell with multiple copies for chromosome 1 and CD30 positive multinucleated Reed-Sternberg-like cell with different copy numbers in each nucleus for chiromosome 1. For color illustration see page 102. 
cally analyzed for expression of $\mathrm{A}$ - and B-type lamins, $\mathrm{Ki}-67$ antigen and $\mathrm{CD} 30$ antigen to investigate whether the small and large cells present in the cell line differ in phenotype (figure 1a-d, $1 \mathrm{~h}$ ).

CD30 antigen expression: Remarkably, the majority of small and large cells in the cell line lacked the CD30 antigen, although the catalyzed reporter deposition (CARD) system was used for signal amplification in this immunocytochemical analysis (figure th).

B-type lamin expression: All small and large cells expressed lamin B2 as detected with the antibodies $L N 43, X 223$, and 101B7.2. The expression pattern was homogeneous, with most small and large cells being strongly positive (figure 1a). Lamin B1 was also expressed in the cell line but most cells stained weakly with 119D5. The large cells, however, exhibited higher staining intensities than small cells.

A-type lamin expression: A-type lamins, recognized by antibodies 133A2, R27, and $41 \mathrm{CC} 4$, were expressed in the cell line, in a heterogeneous manner. Both lamin $\mathrm{A} / \mathrm{C}$ and lamin A antibodies showed the same distribution pattern in small cells as well as in large cells in that the periphery of the nuclei was stained and react with a similar percentage of cells.

A-type lamin expression was evaluated in 300 cells, of which $10 \%$ were large cells, in an exponentially growing culture and a nutritionally deprived culture. The expression of A-type lamins increased dramatically in large cells of the nutritionally deprived culture (figures $1 \mathrm{~b}$, 2). Small cells in both culture conditions on the other hand expressed the A-type lamins to varying degrees. Few cells showed a strong reaction whereas most small cells lacked the A-type lamins (figures $1 \mathrm{~b}, 2$ ).

Ki-67 antigen expression: The staining pattern for the proliferation marker Ki-67 was dependent on the growth conditions in the culture. The population of Ki-67 positive small and large cells was considerably larger in an exponentially growing culture than in a nutritionally deprived culture. About $70 \%$ of both small and large cells were $\mathrm{Ki}-67$ positive in an exponentially growing culture, whereas in a nutritionally deprived culture only $40 \%-50 \%$ of both cell types expressed the Ki-67 antigen (figures $1 \mathrm{C}, 2$ ).

Direct comparison of A-type lamin and $\mathrm{Ki}-67$ antigen expression: Double-staining experiments with antibodies against the Ki-67 antigen and A-type lamins (detected with $41 \mathrm{CC} 4$ ) were performed on samples from a nutritionally deprived culture (Table 1, figure 1d). The expression pattern of these antigens was determined in the different cell populations. Most small cells did not express A-type lamins, however, half of these A-type lamin negative cells exhibited the Ki-67 antigen. Few small cells expressed both antigens. On the other hand the majority of large cells were positive for A-type lamins and to a lesser extent also for the Ki-67 antigen.

Table 1. Results of the combined Ki-67 antigein and A-type lamin immunostaining in a nutritionally deprived cell cullture L1236.

\begin{tabular}{|c|c|c|c|c|c|}
\hline \multirow[t]{2}{*}{ Small cells } & \multicolumn{2}{|c|}{ A-type lamin } & \multirow[t]{2}{*}{ Large cells } & \multicolumn{2}{|c|}{ A-type lamin } \\
\hline & negative & positive & & negalimo & posilive \\
\hline negative & $42 \%$ & $10 \%$ & negatiwe & $16 \%$ & $32 \%$ \\
\hline $\mathrm{Ki}-67$ & & & $\mathrm{Kil}-67$ & & \\
\hline positive & $37 \%$ & $11 \%$ & positive & $8 \%$ & $44 \%$ \\
\hline
\end{tabular}




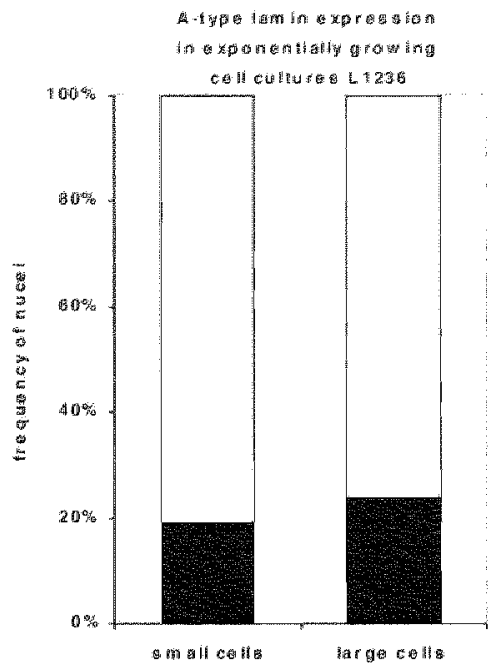

A-

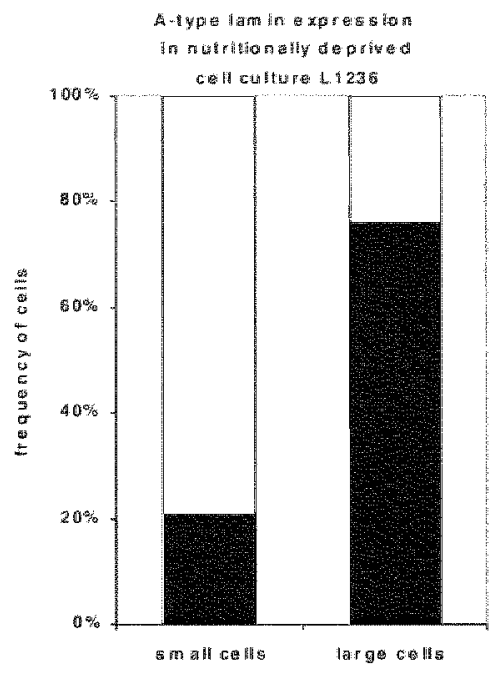

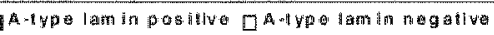
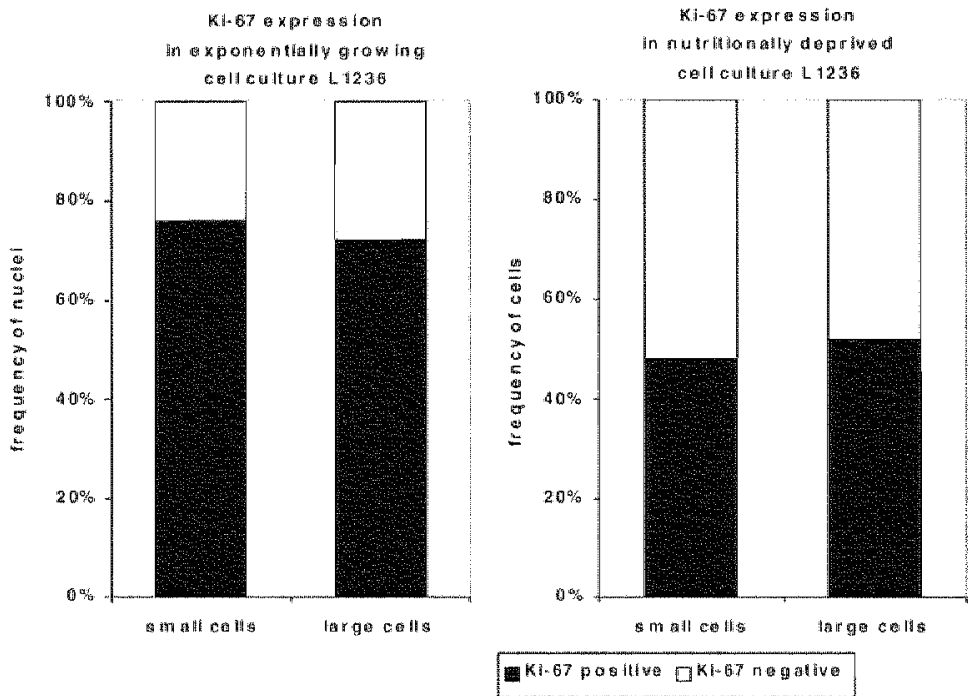

Figure 2. Schematic representation of the frequencies of cels positive for Ki-67 antigen or A-type larnins under different growth conditions and in the small versus large cells.

Genetic constitution of the different cell populations in the tumor and in cell line L1236. Cell line L1236 and the primary tumor from which this cell line was derived, were genetically characterized and compared to each other. Copy numbers for chromosomes 1,9 and 11 were determined in about 300 nuclei per sample. The distribution pattern of chromosome 1 are presented in figure $3 \mathrm{a}$ and $3 \mathrm{~d}$, respectively. Chromosome constitution in the primary tumor was analyzed in paraffin sections, where normal lymphocytes showed most frequently a disomy for chromosome 1 . However, a trisomy for this chromosome was detected in morphologically normal cells (precursor cells) at a very low frequency (figure 3b) and in Hodgkin/Reed-Sternberg cells (figure 3c). This trisomy was also predominantly detected in the cell line (figure $3 \mathrm{~d}$ ). 


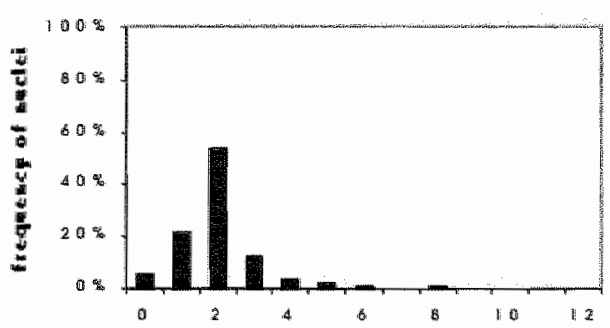

a.

chomosome copy mumbor

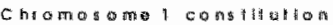

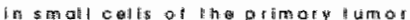

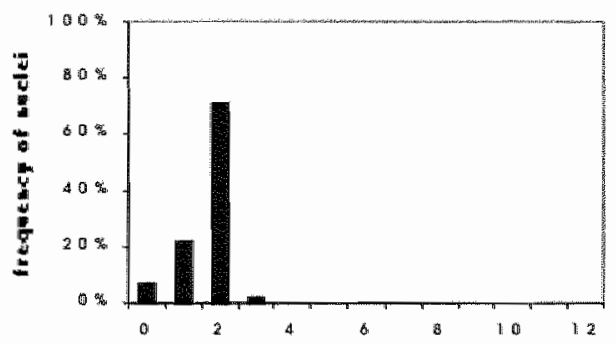

b.

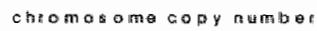

Chimoname 1 constituation

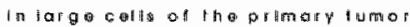

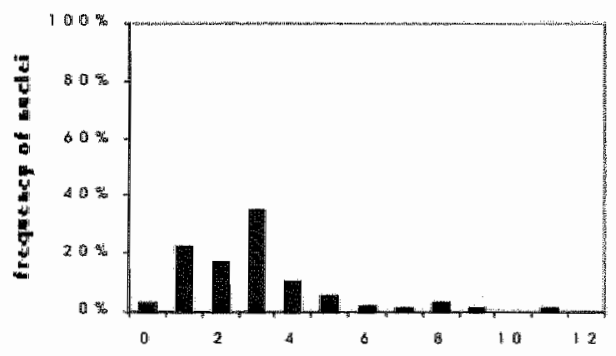

c..

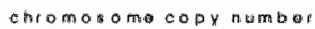

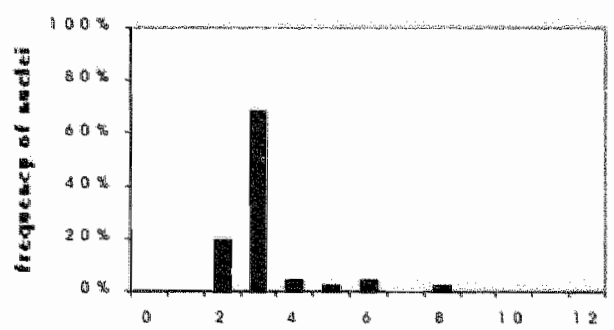

d.

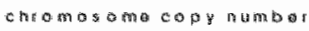

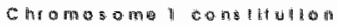
in s⿴囗十

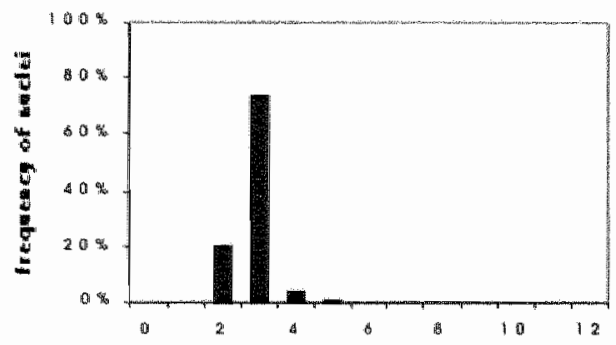

e.

atก

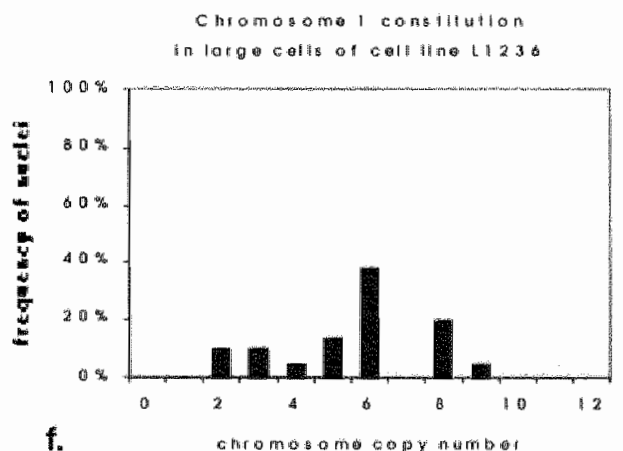

Figure 3. Representation of chromosome 1 copy numbers distribution among the different cell types in both the primary tumor and the Hodgkin-derived cell line L1236.

The majority of morphologically distinguishable (CD30 positive) Hodgkin/Reed-Sternberg cells in the tumor were genetically abnormal for chromosomes 1 and 11, showing a trisomy in mast of the nuclei examined (see figure $3 \mathrm{c}$ for chromosome 1). Although the majority of the Hodgkin/Reed-Sternberg cells showed two signals for chromosome 9 , in a small fraction of these Hodgkin/Reed-Sternberg cells a trisomy for chromosome 9 was detected (figures $1 e, 1 f)$. Multiple copies for chromosomes 1, 9, and 11 were also observed in Hodgkin/ Reed-Sternberg cells. Figure 1f shows an example of a Hodgkin/Reed-Sternberg cells with multiple copies for chromosome 1 and 9. Moreover, we detected in this tumor a trisomy for chromosome 1 in (CD30 negative) morphologicaily normal precursor cells (see chapter 5). 
The largest fraction of cells in the cell line, l.e. the small cells, showed a trisomy for chromosomes 1 and 11 (figures $1 \mathrm{~g}, 1 \mathrm{~h}, 3 \mathrm{~d}$ ) and a disomy for chromosome 9 (figure 1g, 3d). Also a minor fraction of cells showed a disomy for chromosome 1 (figures 3d, 3e). Multiple copies for chromosomes 1,9 , and 11 were detected in a fraction of the large cells of the cell line (figures $1 \mathrm{~g}, 1 \mathrm{~h}, 3 \mathrm{f}$ ). The majority of large mononucleated cells gained the double amount of copy numbers for chromosome 1 (six copies), chromosome 9 (four copies), and chromosome 11 (six copies), as compared to the copy numbers observed in the small cells. Furthermore, the majority of multinucleated cells thad two or three nuclei with each nucleus containing different chromosome copy numbers ranging from zero to ten signals for chromosome 1 (figure $1 h$, Table 2).

Table 2. Chromosome 1 constitution of the individual nuclei from multinucleated cells observed in the Hodgkin-derived cell line L1236.

\begin{tabular}{ccccc}
\hline multinucleated cell: & Nucleus I & Nucleus II & Nucleus III & Nucleus II \\
\hline i & 4 & 3 & & \\
ii & 5 & 3 & & \\
lii & 5 & 3 & & \\
in & 7 & 5 & & \\
w & 10 & 5 & & \\
vi & 5 & 3 & 2 & \\
vii & 5 & 5 & 1 & \\
viii & 7 & 3 & 1 & \\
ix & 3 & 2 & 1 & 2 \\
xi & 6 & 5 & 3 & 2 \\
xi & 8 & 4 & 4 & 2 \\
\hline
\end{tabular}

\section{Discussion}

Cell line L1236 has been derived by culturing blood samples from a patient with Hodgkin's disease ${ }^{[30]}$. We show that L1236 can be used as a model system to study Hodgkin/ReedSternberg cell development from a population of potential precursor cells recently shown to be present in classical Hodgkin's disease (see chapter 5). Our conclusions are based on the comparison of the phenotypic and genetic constitution of the different cell populations present in the tumor and represented in the cell line. Also the properties of the different cell types were compared to each other and to the potential precursor cells.

The majority of cells in the cell line lacks the CD30 antigen and is trisomic for chromosomes 1 and 11 . These characteristics corresponded with the constitution observed in the precursor (morphologically normal) cell population in the tumor (see chapter 5), and it is therefore tempting to suggest on basis of these similarities that the cell line L1236 originate from these precursors. However, the cell line consists at least partly of CD30 positive and lamin A positive Hodgkin/Reed-Sternberg-like cells which most probably originate from the CD30 negative, lamin A negative cells. In particular when the cells in culture become nutritionally deprived, a situation that may bare resemblance to the in vivo conditions under which tumor cells grow, the process of progressive differentiation seems to be initiated as concluded from the induction of A-type lamin expression in a major fraction of the large cells. In vivo, it was observed that most Hodgkin/Reed-Sternberg cells were positive for A-type lamins and it was concluded that the tumor cells attained a more mature phenotype during their development than the surrounding ceils which lacked the Atype lamins ${ }^{[i 4]}$. The fact that the llarge mononucleated and multinucleated Hodgkin/ReedSternberg-like cells for which A-type lamin positivity indicates a relatively high degree of 
differentiation still show immunoreactivity for the $\mathrm{Ki}-67$ antigen indicates that the se cells retain their proliferative potential ${ }^{24}$, 2 is . Ki-67 antigen expression may, however, also occur during DNA endoreduplication without cellular division. However, also a considerable fraction of lamin A positive, but $\mathrm{Ki}-67$ antigen negative cells are found amongst the large, most likely more differentiated, cells, which is in accord with our results in Hodgkin tumors ${ }^{\text {idy }}$. The results of the genotypic studies reveal a two-step process in the generation of the genetically instable, polysomic Reed-Sternberg-like cells from the small, presumed pre. cursor cells which exhibit a trisomy for chromosomes 1 and 11 , and a disomy for chromosome 9. The first step seems to involve endoreduplication without nuclear division, result:ing in Hodgkin-like, large cells with a hexasomy for chromosomes 1 and 11, and a tetrasomy for chromosome 9. The second step involves endoreduplication, with nuclear division, resulting in multinucleated Reed-Sternberg cells. The heterogeneity in the distribution of chromosome 1 indicates a considerable genetic instability in these cells. Furthermore this heterogeneity also excludes the possibility that Reed-Sternberg cells originate from cell fusion, since the homogeneous (trisomic) chromosome 1 distribution in the small cells of the cell line L1236 would then give rise to multinucleated cells with a homogeneous genetic constitution amongst the individual nuclei.

In conclusion, A-type lamin expression increased dramatically in the large Hodgkin/ReedSternberg-like cells of a nutritionally deprived culture but maintained at the same level in the small cells, suggesting that Hodgkin/Reed-Sternberg-like cells attain a more differentiated phenotype than the small (precursor) cells. Furthermore, the majority of the genetically aberrant cells in the cell line lacked CD30 staining, suggesting that the cell line originates from genetically aberrant, CD30 negative, morphologically normal precursor cells in the tumor. This population of CD30 negative cells in the cell line have proliferative potential but also have the ability to differentiate into Hodgkin-like and Reed-Sternberg-like cells.

\section{Acknowledgements:}

We thank Professor V. Diehl for providing the Hodgkin-derived cell line L1236. Dr. E.B. Lane, Dr G. Krohne, Dr. Y. Raymond and Dr. G. Warren are acknowledged tor providing the lamin antibodies. Furthermore we are grateful to the Nijbakker-Morra Foundation and Ank van Vilssingen Foundation for their financial support.

\section{References}

1. Adams, J. Biotin amplification of biotin and horseradish peroxidase signals in histochemical stains. J Histochem Cytochem 40: 1457 (1992)

2. Bobrow, M. Harris, T, Shaughnessy, Kand Litt, G. Catalyzed reporter deposition, a novel method of signal amplification. Application to immunoassays. I immunol Methods $125: 279(1989)$.

3. Bridger, J, Kill, ${ }_{1}$, OFarrell, Mand Hutchison, C. Intemal lamin structure within Gl nuclei of humar dermal fibroblasts. Cell Sici. 104: 297 (1993).

4. Broers, J, Machiels, B, Kuijpers, H. Smedis, F, van den Kieboom, $\mathrm{A}$, Raymond, Y and Ramaekers, F. A- and B-type lamins are differentially expressed in normal human tissues. Histochem. Coll Biar. 107: 505 (1997).

5. Burke, $B, T o o z e, G$ and Warren, $G$. A monocional antibody which recognises each of the nuclear lamin polypeplides in mammalian cells. EMBO J.2: 361 (1983).

6. Cance, W, Chaudhary, N. Worman, Hل, Blobel, G and Cordon-Cardo, C. Expression of the nuclear lamins in normal and neoplastic human tissues. J. Exp. Clin. Cancer Res. 11: 233 (1992).

7. Coates, P, Hobbs, P, Crocker, J, Rowlands, D, Murray, P, Quinlan, R and Hall, P. Identification of thes antigen recognized by the monoclonal antibody BU31 as lamins $A$ and $C$. J. Pathol. 178: 21 (1996).

8. Cooke, $\mathrm{H}$ and Hindley, J. Cloning of human satellite III DWA different components are on different chromosomes. Nucleic Acid Res. 6: 3177 (1979). 
Guilly, M, Kolb, J, Gost, F, Godeau, Fand Courvalin, J. Lamins $A$ and $C$ are not expressed at early stages of human lymphocyie differentiation. Exp. Cell Res. 189:145 (1990).

10. Hoger, $T$, Zatloukal, $K$, Waizenegger, I and Krohne, G. Characterization of a second highly conserwed B-type lamin present in cells previously thought to contain only a single B-type lamin. Chromosoma 100: 67 (1990).

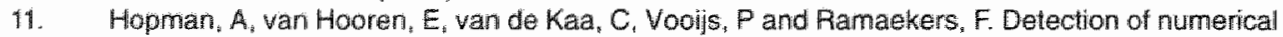
chromosome aberrations using in situ hybridization in paraftin sections of routinely processed bladder cancers. Mod Pathol 4: 503 (1991).

12. Hozák, P, Sasseville, M-J, Raymond, $Y$ and Cook, P. Lamin proteins form an intemal nucleoskeleton as well as a perpheral lamina in human cells. J. Cell SCl. 108: 635 (1995).

13. Jansen, M, Hopman, A, Haesevoets, A, Gennotte, I, Bot, F, Arends, J, Famaekers, F and Schouten, H. Chromosomal abnormalities in Hodgkin's disease are not restricted to Hodgkin/Reed-Sternberg cells. J Pathol 185: 145 (1998).

14. Jansen, M, Machiels, B, Hopman, A, Broers, ${ }_{\text {, B }}$ Bot, F, Arends, J "Ramaekers, F and Schouten. H. Comparison of $\mathrm{A}$ and $\mathrm{B}$-type lamin expression in reactive lymph nodes and nodular sclerosing Hodgkin's disease. Histopathology 31: 304 (1997).

15. Jox, A, Zander, T, Diehl. V and Wolf, J. Clonial relapse in Hodgkin's disease. N Engl J Med 337: $499(1997)$.

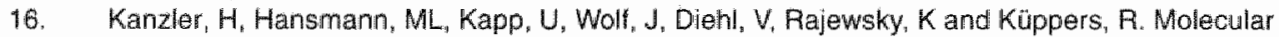
single cell analysis demonstrates the derivation of a peripheral blood-derived cell line (L1236) from the Hodgkin/Reed-Sternberg cells of a Hodgkin's lymphoma patient. Bload 87: 3429 (1996).

17. Moyzis, $\mathrm{F}$, Albright, K, Bartholdi, M, Cram, L, Deaven, L, Hildebrand, $C$, Joste, $N_{1}$ Longmire, $\mathbb{N}_{x}$ Meyme, J and Schwarzacher-Fobinson, T.Human chromosome-specific repetitive DNA sequences: novel markers for genetic analysis. Chromosoma 95: 375 (1987).

18. Pinkel, D, Landegent, J, Collins, C, Fuscoe, J, Seagraves, R, Lucas, J and Gray, J. Fluorescence in situ hybridization with human chromosome-specific libraries: detection of trisomy 21 and translocations of chromosome 4. Proc. Natl. Acad. Sci. USA 85: 9138 (1988).

19. Röber, $\mathrm{R}$, Weber, $\mathrm{K}$ and Osborn, M. Differential timing of nuclear lamin AvC expression in the various organs of the mouse embryo and the young animall: a developmental study. Development $105.365(1989)$.

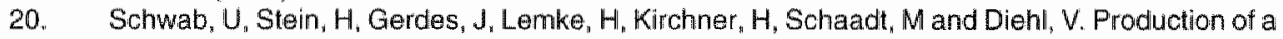
monoclonal antibody specific for Hodgkin and Sternberg-Reed cells of Hodgkin's disease and a subset of normal lymphoid cells. Nature 299:65 (1982).

21. Schwarting, R, Gerdes, J, Durkop, H, Falini, B, Pileri, S and Stein, H. BER-H2: a new anti-Ki-1 (CD30) monoclonal antibody directed at a formol-resistant epilope. Blood 74: 1678 (1989).

22. Speel, $E_{\text {"Ramaekers }} F$ and Hopman. A. Sensitive multicolor fluorescence in situ hybridization using catalyzed reporter deposition (CARD) amplication. J Histochem Cytochem 45: 1439 (1997).

23. Trudel, M, Oligny, L, Caplan, S, Caplan, C. Schipper, H and Wang, E. Statin - a novel marker of nonproliferation (Expression in nonneoplastic lymphoid tissues and follicularlymphomas). Am. J. Clin. Pathol. 101: 421 (1994).

24. Verheijen, R, Kuijpers, H, Schingeman, R, Boehmer, H, Van Driel, R, Brakenhof, G and Ramaekers, F. Ki67 detects a nuclear matrix associaled proliferation antigen. Part I. Intracollular localisation during interphase. J Coll Sci92: 123 (1989).

25. Vertheilen, R, Kuljpers, H, Van Driel, R, Beck, J, Van Dierendonck, J, Brakenhoff, Gand Ramaekers, F. Ki67 detects a nuclear matrix associated proliferation antigen. Part II. Localisation in mitotic cells and association with chromosomes. J Cell Sci $92: 531$ (1989).

26. Wang, N, Pan, Y, Heiden, T and Tribukait, B. Improved method for retease of cell nuclei from paraftin-embedded cell material of squamous cell carcinomas. Cytometry 14:931 (1993).

27. Waye, J, Creeper, $L$ and Willard, H. Organization and evolution of alpha satellite DNA from human chromosome 11. Chromosoma 95: 182(1987).

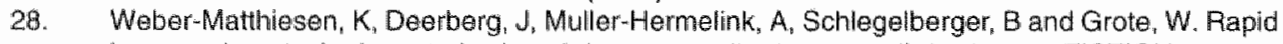
immunophenotypic characterization of chromosomally aberrant cells by the new FICTION method. Cytogenet Cell Genet 63: 123 (1993).

29. Weber-Matthiesen, K, Pressl, S, Schlegelberger, B and Grote, W. Combined immunophenotyping and interphase cytogenetics on cryostat sections by the new FICTION method. Leukemia 7: 646 (1993).

30. Woll, J, Kapp, U, Bohlen, H, Konnacker, M, Schoch, C, Stahl, B, Mucke, S, von Kalle, C, Fonatsch. C. Schaeter, HE, Hansmann, M-L and Diehl, V. Petipheral blood mononuclear cells of a patient with advanced Hodgkin"s lymphoma give rise to permanently growing Hodgkin-Reed Stemberg cells. Blood 87: 34 18 (1996).

31. Zatloukal, K, Denk, H, Spurej, G and Hutter, H. Modulation of protein composition of nuclear lamina reduction of lamins-B1 and lamins-B2 in livers of griseofulvin-treated mice. Lab. Invest. 66: 589 (1992). 


\section{Chapter 7}

\section{Summary and General Discussion}

\section{Summary}

This thesis describes the phenotyping and genotyping of both Hodgkin/Reed-Sternberg cells as well as morphologically normal cells in Hodgkin's disease. It is generally accepted that Hodgkin/Reed-Sternberg cells are part of the malignant cell fraction in Hodgkin's disease, but they constitute only a minor fraction of cells in the tumor ${ }^{[3.15]}$. Hodgkin/Reed-Sternberg cells have been extensively analyzed to determine their origin and nature. Recently it has been concluded that the Hodgkin/Reed-Sternberg cells are derived from B-lymphocytes

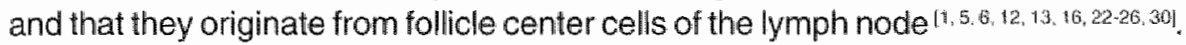
We hypothesized that the malignant clone in Hodgkin's disease not only consists of Hodgkin/ Reed-Sternberg cells, but also includes morphologically normal cells, which may be their progenitor cells. Flow cytometric analysis of Hodgkin's disease showed that the aneup loid cell fraction exceeded the Hodgkin/Reed-Sternberg cell population, indicating that other cells should also contain an aberrant genetic constitution [7]. Therefore, morphologically normal cells were investigated in this study in an attempt to identify precursor cells of the Hodgkin/Reed-Sternberg cells amongst this bystander cell population.

For the analysis of the phenotype and genotype of cells a novel triple-color detection procedure for brightfield microscopy has been developed (chapter 2) and was used to determine the phenotype and genetic constitution of both Hodgkin/Reed-Sternberg cells and morphologically normal cells (chapter 5). The procedure allowed a combined detection of phenotypic and genetic parameters. It was demonstrated for this purpose that two peroxidase detection reactions could be performed using different precipitating reagents, such as diaminobenzidine (brown) and tetramethylbenzidine (green). A mild acid treatment was used as an inactivation step between the two peroxidase detection reactions. In chapter 5 , the two peroxidase enzyme reactions described in this procedure were used to determine CD30 and chromosome constitution of cells in Hodgkin's disease.

The phenotypic constitution of Hodgkin/Reed-Sternberg cells and morphologically normal cells has been analyzed and compared to determine whether certain characteristics may distinguish precursor cells in Hodgkin's disease and link them to Hodgkin/Reed-Sternberg cells. For this purpose lamin subtype and Ki-67 antigen expression have been analyzed in reactive lymph nodes and in Hodgkin's disease (chapter 3 ). It is shown that Hodgkin/ Reed-Sternberg cells express A-type lamins, which indicates that these fumor cells are more differentiated than the morphologically normal cells that mostly lack A-type lamins. In general the expression of A-type lamins coincided with the absence of the cell proliferation marker Ki-67, although a small fraction of apparently differentiated (lamin A positive) Hodgkin/Reed-Sternberg cells did show reactivity with the Ki-67 antibody. Furthermore, 
lamin B2 is present in Hodgkin/Reed-Sternberg cells but also in most bystander cells, with the exception of the follicle center cells of the reactive lymph node. Although differences in phenotypic constitution between Hodgkin/Reed-Sternberg cells and the morphologically normal cells exist, they in themselves were not able to recognize precursor cells in Hodgkin's disease.

The genetic constitution of Hodgkin/Reed-Stemberg cells and morphologically normal cells was analyzed to see whether or not aneuploidy is restricted to the Hodgkin/Reed-Sternberg cells. Chapters 4 and 5 describe the results obtained with the in situ hybridization technique applied on Hodgkin's disease. In chapter 4 , it has been demonstrated in six cases that not only Hodgkin/Reed-Sternberg cells but also very small populations of morphologically normal cells gain numerical chromosome abnormalities. The phenotypic constitution of these genetically aberrant, morphologically normal cells has been extensively explored in two cases (chapter 5), containing a relatively high traction of such cells, showing that they express the CD19-antigen and lack the CD30-antigen. This indicates that the genetically aberrant, morphologically normal cells are of a B-lymphocyte origin. Results of chromosome analyses suggest that they are precursor cells of the Hodgkin/Reed-Sternberg cells, which gain additional chromosomal abnormalities during the development into Hodgkin/Reed-Sternberg cells.

In chapter 6 phenotypic and genetic characteristics of Hodgkin/Reed-Sternberg cells and of morphologically normal cells observed in the previous studies (chapters 3-5) have been analyzed in a cell line derived from a patient with Hodgkin's disease and compared to the original tumor. It was demonstrated that the expression of A-type lamins was increased in Hodgkin/Reed-Sternberg-like cells whereas small cells showed no increase. This suggests that the large Hodgkin/Reed-Sternberg-like cells are more differentiated than the small cells. The lack of CD30 antigen in the majority of small and large cells of the cell line, and the chromosomal abnormalities observed in these cells suggest that the cell line contain cell populations also observed in the tumor. Furthermore, the genotype of ReedSternberg-like cells in the cell line as compared to that of small cells, indicates that the large cells result from endoreduplication and not from cell fusion.

\section{General discussion}

Reflecting upon the data presented in this thesis, it can be stated that an important piece has been added to the complicated jigsaw puzzle called Hodgkin's disease. The technique we used in this quest was a combined immunocytochemistry and in situ hybridization procedure. This combined procedure allowed us to identify a precursor cell population in Hodgkin's disease. These precursor cells have been characterized as CD30 negative B-lymphocytes, and their malignant nature is demonstrated by their chromosomal abnormalities.

The value of this work lies in the identification of these precursor cells and in describing the in situ hybridization procedure to identify them. However, the identification of the precursor cells is only at its beginning. These cells have to be characterized phenotypically and genotypically in more detail and the position of the precursor cells in the sequence of events involved in tumor cell development has to be established for Hodgkin's disease (see figure) $\left.{ }^{[27}, 35\right]$ 
Normal B-lymphocyte development in follicle centre

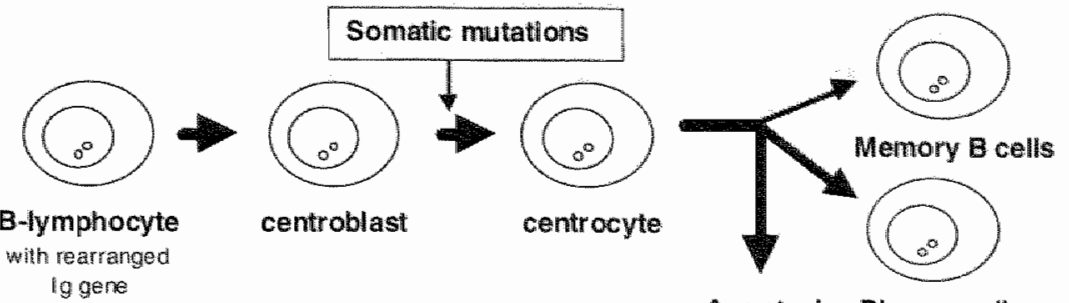

Apoptosis Plasma cells

Tumor cell development in Hodgkin's disease

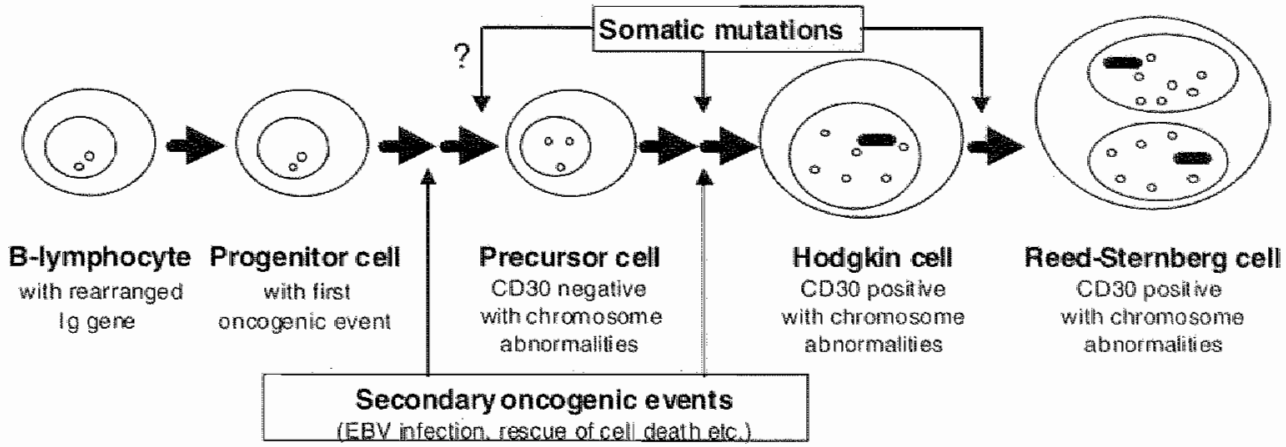

From the identification of immunoglobulin gene rearrangements in Hodgkin/Reed-Sternberg cells it may be inferred that the progenitor and precursor cells are derived from follicle centre cells. At some point the precursor cells transform, acquiring the morphology of a Hodgkin cell, including the expression of CD30. This transformation event may perhaps be compared with the development of a centroblast out of a naive lymphocyte in the follicle centre upon activation by antigen (see figure). Indeed cells with the morphology of Hodgkin cells and even of Reed-Stermberg cells may be found in normal lymph nodes upon activation. The comparison with the events in a normal follicle centre ends at this point, since centrocytes are not formed out of Hodgkin cells but instead multinucleated Reed-Sternberg cells emerge, perhaps through endoreduplication.

Analysis of tumor cell development in Hodgkin's disease, however, may be performed further against the background of the dynamics in the follicle centres [19, 29]. From this point of view, the role of activation by antigen has to be addressed as well as the role of $T$-cell help, next to B-cell maturation. Precursor cells, therefore, have to be characterized for phenotypic and genetic markers in order to obtain a proper understanding of the molecular mechanisms involved, for example, in activation, in differentiation and in programmed cell death rescue.

If activation by antigen would be a critical factor in lymphocyte development, the question remains which antigen in Hodgkin's disease is the critical factor for the transformation of the precursor cell into a Hodgkin/Reed-Sternberg cell? Epstein-Barr virus related antigens might be good candidates, because Hodgkin/Reed-Sternberg cells of classical Hodgkin's disease are often infected with Epstein-Barr virus ${ }^{[11,14,42.45]}$. This virus has the ability to immortalize B-lymphocytes and it was demonstrated that the Epstein-Barr virus LMP1 antigen modulates the phenotype of tumor cells in Hodgkin's disease and induces in vitro morphologically normal cells to transform into Hodgkin/Reed-Sternberg-like cells 
110.11.21] "Furthermore, EBV-positive lymphocytes obtained from Hodgkin's disease were able to generate EBV-associated tumors in SCID mice [17, 32]. This suggests that EBVantigens may be present in precursor cells and that these antigens might have the ability to transform precursor cells into tumor cells. However, it is believed that EBV associated antigens do not initiate the transformation process in Hodgkin's disease. Therefore, other sofar unidentified non-EBV antigens inay be of importance for the initiation of tumor cell development.

Another important event during the differentiation process of B-lymphocytes is the rearrangement of immunoglobulin genes and the occurrence of somatic (hyper)mutations ${ }^{[4]}$. Furthermore, it is suggested that lymphocytes with mutated rearranged immunoglobulin genes may undergo other genomic alterations, such as deletions, duplications and translocations [3.20]. For Hodgkin's disease, it is already demonstrated that Hodgkin/ReedSternberg cells contain immunoglobulin gene rearrangements with somatic hypermutations and have also acquired genomic instability $11,5,12,16,25,26,30,34,36,37,39,40,44]$. The clonal derivation of primary Hodgkin/Reed-Sternberg cells from genetically aberrant but morphologically normal cells, i.e. the precursor cells, has to be demonstrated in future studies by detection of immunoglobulin gene rearrangements from single cells of both fractions ${ }^{\text {t22. }}$. 23.41]. The immunoglobulin rearrangement status of the precursor cell relative to the Hodgkin/ Reed-Sternberg cell is of vital importance to determine whether the precursor cell has a naive lymphocyte configuration or has acquired somatic mutations ${ }^{\text {as: }}$. Some of the mutations acquired during the transformation into Hodgkin/Reed-Sternberg cell might be "crippling" mutations. Such mutations may block on the one hand the maturation potential and on the other hand block the apoptosis machinery, which would otherwise be activated. Apoptosis is used for the antigen-driven selection of lymphocytes in the follicle centre. It is most evident in the light zone of the follicle centre, in which the centrocytes reside. It is suggested that immunoglobulin-negative centroblasts are unaffected by apoptosis. This indicates that (antigen specific) cell death in the follicle centre may be mediated by surface immunoglobulin engagement ${ }^{|19|}$. Therefore, cells which have surface immunoglobulins, but have lost antigen binding or show a reduced antigen binding, may die due to the activation of the apoptotic pathway ${ }^{[31]}$. Moreover, it is believed that the apoptotic events are triggered before the onset of somatic mutations [27]. All this, and the observation of (anti)apoptotic markers such as bax, fas, bcl-2 and bcl-x in Hodgkin/Reed-Sternberg cells, indicate that they may be derived from immunoglobulin-negative centroblasts or from centrocytes with an inadequate antigen binding capacity due to the failure of Hodgkin//ReedSternberg cells to activate the apoptotic machinery ${ }^{22.29 .33 .38,46 .}$. Consequently, the precursor cells also originate from centroblasts or centrocytes and, similar to the Hodgkin/ReedSternberg cells, fail to trigger apoptosis. However, the exact molecular mechanism of cell death inhibition in precursor cells and Hodgkin/Reed-Sternberg cells is still an enigma and has to be elucidated in future studies.

A striking difference between centroblasts and centrocytes is their proliferative capacity. Centroblasts are highly proliferative, whereas centrocytes do not divide ${ }^{[4,18,27]}$. Proliferation markers have been detected in Hodgkin/Reed-Sternberg cells. However, only a very small population of tumor cells (about $1 \%$ ) is detected in the tumor area, implying a low frequency of cell division for Hodgkin/Reed-Sternberg cells. Therefore, the Hodgkin/ReedStemberg cells resemble more likely the centrocytes than centroblasts, not only due to their proliferative capacity but also to their mutations in the rearrranged immunoglobulin genes. The phenotype of precursor cells, on the other hand, most probably matches with a (pre)centroblast phenotype, but conclusive evidence has to be collected.

Finally, receptors and cytokines involved in the interactions between T-helper cells and 
Hodgkin/Reed-Sternberg cells may be of importance in the transformation process and. therefore, have to be characterized for the interaction between T-helper cells and precursor cells: T-lymphocytes in the follicle centre and surrounding the Hodgkin/Reed-Sternberg cells in Hodgkin's disease are (activated) CD4-positive T cells ${ }^{[3}$ 18]. Cytokines, such as IL-1, IL-2, IL-6, TNF, CD30-ligand, CD40-ligand and CD95-ligand are important for the interaction between Hodgkin/Reed-Sternberg cells and T-lymphocytes, but may also important for the interaction between precursor cells and T-lymphocytes. On the other hand, IL-4 and IFN-g are cytokines which are involved in polykaryon formation "I9! One may speculate that due to the above-mentioned interactions, T-lymphocytes may induce polykaryon formation in precursor cells via IL-4 and IFN-g secretion, and therefore, transform them into Hodgkin/Reed-Sternberg cells. However, other cyltokines and receptors might be of importance for the initiation of tumor cell development in Hodgkin's disease.

Future studies in Hodgkin's disease have to elucidate the molecular mechanisms involved in the transformation of precursor cells into Hodgkin/Reed-Sternberg cells.

\section{Conclusion}

This thesis shows that the malignant cell population in Hodgkin's disease is not limited to the Hodgkin/Reed-Sternberg cells by identifying a small precursor cell population that have numerical chromosome abnormalities. These precursor cells have the ability to proliferate and to differentiate into Hodgkin and Reed-Sternberg cells. During the process of differentiation genetic aberrations accumulate in the Hodgkin/Reed-Stemberg cells. Finally, on basis of the observed genetic relationships, the precursor cells are suggested to be progenitor cells of the Hodgkin/Reed-Sternberg cell population.

\section{References}

1. Braeuningeir, A, Küppers, R, Strickler, J, Wacker, H, Rajewsky, Kand Hansmann, M-L. Hodgkin and Reed-Sternberg cells in lymphocyte predominant Hodgkin's disease represent clonal populations of germinal center-derived tumor colls. Proc Natl AcadSei USA 94: 9337 (1997).

2. Brousset, P. Benharroch, D, Krajewski, $S$, Laurent, $G$. Meggetto. F, Rigal-Huguet, F, Gopas, a, Prinsloo, I, Pris J, Delsol, G, Reed, J and Schlawifer, D. Frequent expression of the cell death. inducing gene baxin Reed-Sternberg cells of Hodgkin's disease. Blood87: 2470 (1996).

3. Burke, J. Hodgkin's disease: histopathology and differential diagnosis. In: D. Knowles, ed. Neoplastic Hematopathology. Baltimore: Williams \& Wilkins; 497 (1992).

4. Burrows, P, Keamey, J, Schroeder, $\mathrm{H}$ and Cooper, M. Normal B lymphocyte differentialion. Bailhière's Clin Haematol 6: 785 (1993).

5. Delabie. J, Tierens, A, Gravil, T, Wu, G, Weisenburger, D and Chan, W. Phenotype, genotype and clonality of Reed-Sternberg cells in nodular sclerosis Hodgkin's disease: results of a single-cell study. Br J Haematol $94: 198$ (1996).

6. Delabie. J, Tierens, A, Wu, G, Weisenburger, D and Chan, W. Lymphocyte predominance Hodgkin's disease: lineage and clonality determination using a single-cell assay. Blood 84 : 3291 (1994).

7. Erdkamp, FL, Schouten, HC, Breed, WP, Janssen, WC, Hoffmann, JJ, Schutte, B and Bliham, GH. DNNA aneuploidy in Hodgkn's disease: a multiparameter flow cytometric analysis. LQuk Lymphoma 12: $297(1994)$.

8. Goossens, T, Klein, U and Küppers, R. Frequent occurrence of deletions and duplications during somatic thypermutation: Implications for oncogene translocations and heavy chain disease. Proc Natl Acad Sci USA 95: 2463 (1998).

9. Grüss, H-J, Pinto, A, Duyster, J Poppema, $S$ and Herrmann, F. Hodgkin's disease: a fumor with disturbed immunological pathways. Immunol Today 18: 156 (1997)

10. Herbst, $H$, Raff, $T$ and Stein, $H$. Phenotypic modulation of Hodgkin and Reed-Stemberg cells by 
Epstein Barr Virus. JPathol 179:54 (1996).

11. Herbst, $H_{i}$ Stain, $H$ and Nedobitek, $Q$. Epstein-Barr virus and $C D 30+$ malignarit lymphomas. Crit Fev oncog 4: 191 (1993).

12. Hummel, M, Marafiot, T, Zlemann, $k$ and Stein, H. Ig rearrangements in isolated Reed-Stemberg cells: conclusions from four different studies. Ann Oncol7 (Sup 4): 31 (1996).

13. Hummel, M, Ziemann, $K$, Lammen, $H$, Piler, $S$, Sabattini, E and Stein, H. Hodgkin's disease with monocional and polyclonal populations of Reed-Sternberg cells. N Engl J Med 333: 901 (1995).

14. Jarret, $R$, Armstrong, $A$ and Alexander, $F$. Epstein-Barr virus and the epidemiology of Hodgkin's disease Ann Oncol 7 (sup 4): S5 (1996).

15. Kadin, M. Pathology of Hodgkin's disease. Current Opinion in Oncology 6: 456 (1994).

16. Kamzler, $H$, Küppers, R, Hansmann, ML and Rajewsky, K. Hodgkin and Reed-Sternberg cells in Hodgkin's disease represent the outgrowth of a dominant tumor clone derived from (crippled) germinal center B cells. J Exp Med 184: 1495 (1996).

17. Kapp, U, Woll, J, Hummel, M, Pawlita, M, von-Kalle, C, Dallenbach. F, Schwonzen, M, Krueger, GR, Muller-Lantzsch, N, Fonatsch, C and al, e. Hodgkin's lymphoma-derived tissue serially transplanted into severe combined immunodeficient mice. Blood 82: 1247 (1993).

18. Kelsoe. G. The germinal center: a crucible for lymphocyte selection. Semin Immuno ;8:179 (1996).

19. Kalsoe, G. Lite and death in germinal centers (redux). Immunity 4: 107 (1996).

20. Kirsch, I and Lista, F. Lymphocyte-specific genomic instability and risk of lymphoid malignancy. Semin Immunol 9: 207 (1997).

21. Knecht, $H$, McQuain, $C$, Martin, J, Rothenberger, 3 , Drexler, $H$, Berger, $C$, Bachmann, $E_{x}, K i t t e r, E$, Odermatt, B and Quesenberry, P. Expression of the LMPI oncoprotein in the EBV negative Hodgkin disease cell line L-428 is associated with Reed-Stemberg cell morphology. Oncogene 13: 947 (1996).

22. Küppers, $R$, Hansmann, ML, Diehl, $V$ and Rajewsky, $K$. Molecular single-cell analysis of Hodgkin and Roed-Sternberg cells. Mol Med Today 1: 26 (1995).

23. Küppers, R, Kanzler, H, Hansmann, ML and Rajewsky, $K$. Single cell analysis of Hodgkin/ReedSternbergl cells. Ann Oncol 7 (Sup 4): 27 (1996).

24. Küppers, $R$ and Rajewsky, K. The ongin of Hodgkin and Reed/Sternberg cells in Hodgkin's disease. Annu Rev Immunol 16: 471 ( 1998$)$.

25. Küppers, R, Rajewsky, K, Zhao, M, Simons, G, Laumann, R, Fischer, R and Hansmann, ML. Hodgkin's disease: clonal lg gene rearrangements in Hodgkin and Feed-Sternberg cells picked from histological sections. Ann N Y Acad Sci 764: 523 (1995).

26. Leoncini, L, Spina, D, Megha, T, Gallorini, M. Tosi, P. Hummel, M, Stein, H, Pileri, S, Kraft, R, Laissue, JA and Cottier. H. Cell kinetics, morphology, and molecular IgVH gene rearrangements in Hodgkin's disease. Leuk Lymphoma 26: 307 (1997)"

27. Liu, Y-J Arpin, $C_{\text {, }}$ de Bouteiller, $O$, Curet $C_{*}$ Banchereau, J, Martinez-Valdez, H and Lebecque, $S$. Sequential triggering of apoptosis, somatic mutation and isotype switch during geminal center devellopment. Sem /mmunol 8: 169 (1996).

28. Liu, $Y-J$, Malisan, $F$, de Bouteiller, $O$, Guret, $C_{1}$ Lebecque, $S$, Banchereau, J, Mills, $F$, Max, Eand Mertinez-Valdez, $\mathrm{H}$. Within germinal centers, isolype switching of immunoglobulin genes occurs after the onset of somatic mutation. Immunity $4: 241$ (1996).

29. Lorenzen, J. Thiele, J and Fischer. F. The mummified Hodgkin cell: cell death in Hodgkin's disease. J Pathol 182: 288 (1997).

30. Marafiot, T, Hummel, M, Anagnostopoulos, I. Foss, HD, Falini, B, Delsol, G, Isaacson, PG, Pilleri, S and Stein, H. Origin of nodular lymphocyte-predominant Hodgkin's disease from a clonal expansion of thighly mutated germinal-center B cells. N EnglJ Med 337; 453 (1997).

31. Mcmeyzer-Williams, M. Immune response decisions at the single cell level. Semin Immunol 9: 219(1997).

32. Meggetto F, Muller $C_{1}$ Henry, S, Selves, J, Mariamé, B, Brousset, P, Saati, TA and Delsol, G. Epstein-Barr Virus (EBV)-associated lymphoproliferations in severe combined immunodefficient mice transplanted with Hodgkin's disease lymph nodes: Implication of EBV-positive bystander Bilymphocytes rather than EBV-infected Reed-Sternberg cells. Blood 87: 2435 (1996).

33. Messineo, $C$. Jamerson, M, Hunter, E, Braziel, R. Bagg, A, Irving, S and Cossman, J. Gene expression by single Reed-Sternberg cells: Pathways of apoptosis and activation. Blood'91: 2443 (1998).

34. Nolte, $M$, Wemer, $M$, von Wasielewski, $A$, Nietgen, $G$, Wilkens, $L$ and Georgil, $A$. Detection of numerical karyotype changes in the giant cells of Hodgkin"s lymphomas by a combination of FISH and immunohistochemistry applied to paraffin sections. Histochem Cell Bio/ 105: 401 (1996).

35. Pasculal, $V, L i u, Y, J$ and Banchereau, J. Normal human B cell sub-populations and their malignant counterparts. Bailière's Clin Haematol 10: 525 (1997).

36. Pringle, JH, Shaw, JA, Gillies, A and Lauder, I. Numerical chromosomal aberrations in Hodgkin's disease detected by in situ hybridisation on routine paraffin sections. J Clin Pathol 50: 553 (1997).

37. Roth, J, Daus, H, Trümper, L, Gause, A, Salamon-Looijen, M and Pfreundschuh, M. Detection of 
immunoglobulin heavy-chain gene rearrangement at the single-cell level in malignant lymphomas: no rearrangement is found in Hodgkin and Reed-Stemberg cells. Im J Cancer 57 . 799 (1994).

38. Schlaifer, D, March, M, Krajewski, S, Laurent, G, Pris, J, Delsol, G, Reed J and Brousser, P. High expression of the bol-x gene in Reed-Stemberg cells of Hodgkin's disease. Shood85: 2671 (1995).

39. Schoulen, $H$, Sanger, W, Duggan, $M$, Weisenburger, $D$, Maclennan, $K$ and Amitage, J. Chromosomal abnormalities in Hodgkin's disease. Blood 73: 2149 (1989).

40. Tilly, $H$, Bastard, $C$, Delastre, $T$, Duval, $C$,Bizet, M, Lenormand, $B$, Dauce, JP, Monconduit, Mand Piguet, H. Cytogenetic studies in untreated Hodgkin's disease. Blood 77: 1298 (1991).

41. Trümper, L, Brady, G, Bagg, A, Gray, D, Loke, S, Greisser, $H_{3}$, Wagman, $\mathrm{A}$, Brazial, A, Gascoyna, $\mathrm{A}_{i}$ Vicini, S, Iscove, N, Cossman, J and Mak, T. Singlewell analysis of Hodgkin and Reed-Sternberg cells: Molecular heterogeinity of gene expression and p53 mutations. Blood B 1: 3097 (1993).

42. Vassallo, J, Brousset, P, Knecht, $H_{4}$ Lamant, L, Odermatt, BF and Delsol, G. Detection of EpsteinBarr virus in Hodgkin's disease. Applied immunohistochemistry 1: 213 (1993).

43. Wagner, Sind Neuberger, M. Somatic hypermutation of immunoglobulin genes. Annu Rev mmunot 14: $441(1996)$.

44. Weber-Matthiesen, $K$, Deerberg, $J$, Poetsch, $M$, Grote, W and Schlegelberger, B. Numerical chromosome aberrations are present within the CD30. Hodgkin and Reed-Stemberg cells in $100 \%$ of analyzed cases of Hodgkin's disease. Blood 86 : 1464 (1995).

45. Weiss, LM, Movahed, LA, Warnke, RA and Sklar, J. Detection of Epstein-Barr viral genomes in Reed-Stemberg cells of Hodgkin's disease. N Engl M Med 320:502 (1989).

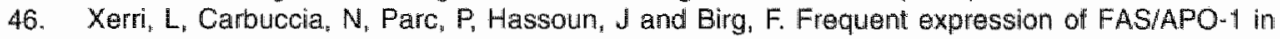
Hodgkin's disease and anaplastic large cell lymphoma. Histopathology 27 : 235 (1995). 

De ziekte van Hodgkin is een kwaadaardige tumor van de lymfklier die voor hel eerst als zodanig beschreven werd in 1832 door Thomas Hodgkin. Het is een ziekte die zich zowel op jonge als op oudere leeftijd kan manifesteren. Dankzij radio-en chemotherapie zijn de overlevingskansen de laatste vier decennia aanzieniljk verbeterd.

Tumorcellen bij de ziekte van Hodgkin werden in het begin wan deze eeuw herkend en beschreven door Reed en Sternberg. De populatie morfologisch duidelijk herkenbare tumorcellen, Hodgkin/Reed-Sternberg cellen genoemd, vormt echter maar $1 \%$ van de totale celpopulatie in de tumor.

Dit proefschrift beschrijft de fenotypering en genotypering van zowel Hodgkin/Reed-Stemberg cellen als van morfologisch normale cellen in de ziekte van Hodgkin. De Hodgkin/ Reed-Sternberg cellen zijn al uitvoerig bestudeerd in andere studies om hun oorsprong en eigenschappen te bepalen. Onlangs is vastgesteld dat Hodgkin/Reed-Sternberg cellen afstammen van B-lymphocyten en waarschijnlijk ontstaan uit cellen van het follikel centrum in de lymfklier.

Onze hypothese is dat de maligne kloon in de ziekte van Hodgkin niet alleen uit Hodgkin/ Reed-Sternberg cellen bestaat, maar ook uit morfologisch normale cellen, die voorloperof zelfs stamcellen van Hodgkin/Reed-Sternberg cellen kunnen zijn. Tot nu toe zijn echter geen voorlopers van Hodgkin/Reed-Sternberg cellen geïdentificeerd. Flow cytometrisch onderzoek bij de ziekte van Hodgkin toonde echter aan dat de populatie cellen met een afwijkende DNA inhouid (aneuploid) groter was dan de populatie aneuploide Hodgkin/ Reed-Sternberg cellen, wat dus betekent dat ook andere cellen genetisch afwijkend zijn. Daarom zijn in ons onderzoek ook morfologisch normale cellen bestudeerd in een poging de voorlopers van Hodgkin/Reed-Sternberg cellen te identificeren.

Een nieuwe driekleuren detectie procedure voor he derveld microscopie werd ontwikkeld om het fenotype en genotype van cellen te kunnen onderzoeken (Hoofdstuk 2), en werd gebruikt bij de fenotypering en genotypering van Hodgkin//Reed-Sternberg cellen en morfologisch normale cellen (Hoofdstuk 5). De methode maakt het mogelijk om (gelijktijdig) zowel fenotypische als genotypische kenmerken te bestuderen. Ten behoeve hiervan werd aangetoond dat twee peroxidase reacties na elkaar uitgevoerd konden worden na tussentijdse inactivatie door een milde zuur behandeling. Verder werden hiervoor verschillende neerslagprodukten gebruikt zoals diaminobenzidine (bruin) en tetramethylbenzidine (groen). Deze procedure werd in hoofdstuk 5 gebruikt om de CD30 en chromosoom samenstelling van de cellen bij de ziekte van Hodgkin vast te stellen. Het fenotype van Hodgkin/Reed-Sternberg cellen en van morfologisch normale cellen werd onderzocht en met elkaar vergeleken om te bepalen of voorlopercellen bij de ziekte van Hodgkin herkend konden worden door fenotypische eigenschappen. Verder werd gekeken of deze eigenschappen in verband gebracht konden worden met het fenotype van Hodgkin/ Reed-Sternberg cellen. De expressie van verschillende lamines en van het proliferatie antigen Ki-67 werden onderzocht, zowel bij reactieve lymtklieren als bij de ziekte van Hodgkin (Hoofdstuk 3). Hodgkin/Reed-Slernberg cellen brachten A-type lamines tot expressie, zodat de tumorcellen meer gedifferentieerd zijn dan de morfologisch normale cellen die namelijk geen A-type lamines bezitten. In het algemeen werden A-type lamines en de celproliferatie marker Ki-67 niet samen tot expressie gebracht, hoewel er een kleine populatie Hodgkin/Reed-Sternberg cellen toch Ki-67 positief was ondanks hun gedifferentieerd fenotype (lamine A positief). Verder was lamine B2 aanwezig in Hodgkin/ Reed-Sternberg cellen en in de meeste omringende cellen, met uitzondering van de cellen in het follikel centrum bij reactieve lymfklieren. De verschillen in fenotype tussen Hodgkin/ 
Reed-Sternberg cellen en morfologisch normale cellen konden echter niet gebruikt worden om voorlopercellen bij de ziekte van Hodgkin op te sporen.

De genetische samenstelling van Hodgkin/Reed-Stemberg cellen en morfologisch normale cellen werd onderzocht om te achterhalen of abnormale chromosoom aantallen (aneuploidie) niet alleen in Hodgkin/Reed-Stemberg cellen voorkomen, maar ook in potentielle voorlopercellen aanwezig zijn. Hoordsiukken 4 en 5 beschrijven de resultaten die verkregen zijn met behulp van de in situ hybridisatie techniek bij Hodgkin/ReedSternberg cellen en morfologisch normale cellen. In hoofdstuk 4 wordt voor zes gevallen aangetoond dat numerieke chromosomale afwijkingen niet alleen in Hodgkin/ReedStermberg cellen woorkomen maar ook in morfologisch normale cellen. Het fenotype van deze genetisch afwijkende, morfologisch normale cellen werd bepaald in hoofdstuk 5 voor twee nieuwe gevallen. De genetisch afwijkende, maar morfologisch normale cellen brachten het B-lymfocyt kenmerkende CD19-antigen tot expressie maar miste het Hodgkin/ReedSternberg cel kenmerkende CD30-antigen. Dit duidt erop dat deze cellen afstammen van Bulyrnfocyten. De resultaten in hoofdstuk 5 toonden verder aan dat deze genetisch afwijkende, morfologisch normale B-lymfocyten waarschijnuljk voorlopers zijn van Hodgkin/ Reed-Sternberg cellen. Deze voorlopercellen verkrijgen gedurende de ontwikkeling tot Hodgkin/Reed-Sternberg cellen extra genetische afwijkingen.

De fenotypische en genotypische kenmerken van Hodgkin/Reed-Sternberg cellen en morfologisch normale cellen zoals die in vorige onderzoeken (hoofdstuk 3-5) waargenomen waren, werden in hoofdstuk 6 onderzocht in een cellijn en vergeleken mel de Hodgkin tumor waarvan de cellijn verkregen was. De expressie van A-type lamines nam drastisch toe in Hodgkin/Reed-Sternberg lijkende cellen in een voedingsarme kweek, terwijl de kleine cellen in de kweek geen toename in A-type lamine expressie lieten zien. Dit duidt erop dat de grote op Hodgkin/Reed-Sternberg lijkende cellen meer gedifferentieerd zijn dan de kleine cellen. De meerderheid van kleine en grote cellen in de cellijn miste het CD30antigen terwijl de chromosoomafwijkingen in deze cellen overeen kwamen met de afwijkingen in Hodgkin/Reed-Sternberg cellen en genetisch afwijkende, CD30 negatieve, morfologisch normale cellen van de tumor. Dit alles wijst erop dat de cellijn ontstaan is uit deze celpopulaties in de tumor. Het genotype van Reed-Sternbergachtige cellen in de cellijn bleek instabieler te zijn dan van de kleine cellen wat zou kunnen betekenen dat grote cellen mogelijk gevormd worden door endoreduplicatie en niet door celfusie.

Concluderend, dit proefschrift toont aan dat de tumorcelpopulatie bij de ziekte van Hodgkin niet alleen uit Hodgkin/Reed-Sternberg cellen bestaat maar ook uit voorlopercellen die numerieke chromosoomafwijkingen bezitten. Deze voorlopercellen kunnen delen en zich ontwikkelen tot Hodgkin/Reed-Sternberg cellen. Gedurende dit rijpingsproces tot Hodgkin/ Reed-Sternberg cel kunnen extra genetische afwijkingen ontstaan. De voorlopercellen kunnen stamcellen van de Hodgkin/Heed-Sternberg celpopulatie zijn op basis van de waargenomen genetische verwantschap. 


\section{Dankwoord}

Dierbare lezer van dit proefschrift, de wetenschappelijke verhandeling zit erop. Rest mil alkeen nog woorden van dank aan $u$ en aan mijn collega's, familie en vrienden voor de interesse en samenwerking.

Beste lezer van deze pagina, niet iedereen kan ik persoonlijk noemen, hienvoor mijn verontschuldigingen.

Dit proefschrift is het resultaat van 5 jaar arbeid en gemeenschappelijk overleg. Het waren jaren van hard werken, soms tot het uiterste, soms "borderline", soms zelfs zonder het licht aan het einde te zien, maar uiteindelijk is het er toch van gekomen.

Als AlO van de vakgroep inteme Geneeskunde had ik mijn werkplek bij de vakgroep Moleculaire Celbiologie \& Genetica, terwijl bij het gemeenschappelijk overleg ook de vakgroep Pathologie aanwezig was. Deze drie vakgroepen will ik daarom bedanken voor de samenwerking, de begeleiding en de steun tijdens soms barre omstandigheden.

In het bijzonder wil ik Ton Hopman en Harry Schouten bedanken. Beste Ton, ondanks dat iji toch geen co-promotor bent geworden, was jij De Hopman. Ons dagelijks contact op de werkwloer en jouw inzet, inzicht en steun hebben een belangrijke bijdrage geleverd aan de totstandkoming van dit proefschrift. Jij hebt mij de verborgen schatten van de FISH techniek laten zien en met jouw enthousiasme heb ik ook grenzen kunnen verleggen. Zonder jouw hulp was dit niet mogelijk geweest. Ik betreur het daarom dat jouw inbreng niet gehonoreerd is.

Beste Harry, als directe begeleider van Interne Geneeskunde en co-promotor, was jij diegene die het project gestalle heeft gegeven. dij waakte over de klinische vraagstelling, waar we samen (en met anderen) soms flinke discussies over hadden, maar het bleef steeds een uitdaging tot aan het eincle toe. Door jouw inbreng en opmerkingen heb ik kennisgemaakt met de klinische invalshoek. Deze bijdrage was voor mij en het proefschrift waardevolen daarvoor ben ik je zeer erkentelijk.

Drie andere mensen die een rol gespeeld hebben bij de begeleiding zijn Jan Willem Arends, Freek Bot en Frans Ramaekers.

Beste Jan Willem, als promator heb jij plaatsgemaakt voor Freek als co-promotor. Onze gedachtenwisselingen waren meestal kort maar krachtig, soms wetenschappelijk, soms over /talië of politiek. maar ze waren bovenalleerzaam. Grazie.

Beste Freek, uiteindelijk ben jij mijn tweede co-promotor geworden. Jouw expertise en inbreng zijn belangrijk geweest voor het onderzoek en het proefschrift. Het was altijd heel erg boeiend om met jou te 
filosoferen over (het ontstaan van) de ziekte van Hodgkin. Verder was het altijd heel plezierig met jou samen te werken dankzil jouw humoristische opmerkingen. Hiervoor mijn dank.

Beste Frans, minn promotor van begin tot eind, zonder jou w hulp en inzet zou het proefschrift niet op tijd af geweest zijn. Je wist mij op de juiste momenten te motjveren om de resultaten miet alleen te verzamelen maar ook te gebruiken. Verder bewonder ik hoe jij een verzameling woorden in lets zinnigs kunt veranderen. Dankzij jou kon het project bij Moleculaire Celbiologie uitgevoerd worden. Voor alles bedankt.

Beste Annick, gelukkig had jij altijd goede zin en met grappige, soms pittige Belgische opmerkingen kon jij mij opvrolijken, ook al ging het soms niet zo goed... Het is ons gelukt, het is af en nu zal je naast mij als paranimf zitten en een beetje trots op ons werk zijn! Lieve Monique, ciao bella Pancia! Bij mij zit het erop, de "bevalling" heb ik achter de rug (werkelijk en wonderlijk), nu ben ij aan de beurt. $1 k$ vind het geweldig dat je, met 7 maanden buik, naast mij wilt staan (sorry, zitten) als paranimf. Jii bent altijd een morele steun geweest en hebt altijd opbeurende woorden gehad. Harm Jan heeft bij de gezelligheid van onze weekendjes een belangrijke rol gespeeld.

Beste Inge, heel wat coupes zijn van het mes afgekomen sinds je bij mij als studente bent komen werken, maar zoals je ziet ben ik jou nog steeds heel erkentelijk voor de bijdrage. Het was altijd heel gezellig met jow en Arnick samen te werken.

Frank, mijn maat bij de sportieve uitdagingen. Mountain-biken is een heel goede therapie tegen opkomende promotie stress. $\mathrm{Dr}$. Frank, bedankt!

Prolessor Diehl, Jürgen Wolf, und Andrea Jox, es war schön nach Köln zu fahren und mit euch über Hodgkin's disease zu diskutieren. Danke schön führ Eure Zusammenarbeit.

Verder wil ik al mijn (ex-)MCB collega's danken voor de gezellige tijd op het lab. Helma, mijn kamergenote. Jij hebt me niet zoveel op de kamer gezien, maar het was fijn om met jou de kamer te delen. Mieke en Marie-Helène, dankzij jullie heb ik geleerd hoe je cellen moet kweken en analyseren. Manon, Joris en Victor wil ik succes wensen met hun promotie-onderzoek en bedanken voor hun belangstelling en de gezellige etentjes. Miriam en Monique, zonder jullie zou het FISH-lab niet kunnen draaien, zouden we als een kip zonder kop zijn. Jullie zorgden ervoor dat we ons in Maastricht en op het lab thuiswoelden. Wiel, de man die alles kan, bedankt voor de (technische) ondersteuning. Jos, Bert, en Guillaume, jullie hebben op het werk (of op de berg) met mij wan gedachten gewisseld over het onderzoek. Hiervoor ben ik jullie zeer erkentelijk. Francine, 
dankzij jou werden details geregeld. Jannie en Christien, het was altijd gezellig om met jullie te joggen en te dineren. Erika, ili stond altijd klaar als er weer eens PCR probleempjes waren. Roger en Jacqui, het was attijd spannend welk gerecht er op het menu stond tijdens onze culinaire uitspattingen. Mieke, Jolanda, Ingrid en Annemarie van Interne, jullie belangstelling en hulp gaven mij het Inteme gevoel. Zonder mijn trouwe labmaatjes Kwik, Kwek, Kwak en Donald was al dit werk niet uitgevoerd.

Pappa, mamma, Pascal en Tina, jullie hebben altijd meegeleefd met onze AlO- en promotie-stress. Pappa en mamma, jullie ondersteuning, begrip en bereidheid ons te helpen tijdens moeilijke perioden, verhuizingen, etc. heb ik altijd enorm gewaardeerd.

More, come te non c'è nessuno. Zonder jou was het me niet gelukt. Bracio e Bacio. Martino, babbo è molto orgoglioso di te!

Maastricht, 25/11/98 



\section{Curriculum vitae}

Maurice Jansen werd geboren op 19 januari 1966 te Nuth. In 1982, 1984 en 1986 behaalde hij respectievelijk het MAVO, HAVO en atheneum B diploma aan het Sint Jans College te Hoensbroek. Hierna is hij begonnen met de studie werktuigbouwkunde aan de HTS te Heerlen en heeft hij gewerkt als administratief medewerker om in 1987 met de studie biologie aan de Landbouwuniversiteit Wageningen te beginnen. Het doctoraal examen werd in augustus 1992 behaald. Tijdens deze studie heeft hij onderzoekservaring opgedaan bij de vakgroepen Functionele Diermorfologie (Dr. R Akster) en Erfelijkkeidsleer (Dr. H van den Broek) van de Landbouwuniversiteit en bij de afdeling Moleculaire Genetica (Dr. M Snoek) van het NKI. Na zijn af́studeren heeft hij als vrijwilliger gewerkt bij de vakgroep Moleculaire Celbiologie \& Genetica (Dr. AHN Hopman) van de Universiteit Maastricht. In 1993 trad hij als Assistent in Opleiding in dienst bij de vakgroep Interne Geneeskunde (Dr. $\mathrm{HC}$ Schouten) van het Academisch Ziekenhuis Maastricht in een samenwerkingsverband met de vakgroepen Moleculaire Celbiologie \& Genetica (Prof. dr. FCS Ramaekers, Dr. AHN Hopman) en Pathologie (Prof. dr. JW Arends, Dr. FulBot). 



\section{Publications}

Maurice PHM Jansen, Anton HN Hopman, Fredrik I Bot, Annick M Haesevoets, Frans CS Ramaekers, and Harry C Schouten. Genotyping and phenotyping of distinct cell populations in the Hodgkin-derived cell line L1236 provides evidence for progressive in vitro differentiation of precursor cells into Hodgkin/Reed-Sternberg-like cells. Submitted.

Maurice PHM Jansen, Anton HN Hopman, Fredrik J Bot, Annick M Haesevoets, Marian JPL Stevens-Kroef, Jan-Willem Arends, Andrea Jox, Jürgen Wolf, Frans CS Ramaekers, and Harry C Schouten. Morphologically normal, CD30 negative B-lymphocytes with chromosome aberrations in classical Hodgkin's disease: The progenitor cell of the malignant clone? Submitted.

Maurice PHM Jansen, Anton HN Hopman, Annick M Haesevoets, Inge AF Gennotte, Fredrik J Bot, Jan-Willem Arends, Frans CS Ramaekers, and Harry C Schouten.Chromosone abnormalities in Hodgkin's disease are not restricted to Hodgkin/Reed-Sternberg cells. J Pathol 185: 145-152 (1998).

Maurice PHM Jansen, Barbie Machiels, Anton HN Hopman, Jos LV Broers, Fredrik J Bot, Jan-Willem Arends, Frans CS Ramaekers, and Harry C Schouten. Comparison of Aand B-type lamin expression in nodular sclerosing Hodgkin's disease and reactive lymph nodes. Histopathology 31, 304-312 (1997).

EJM Speel, MPHM Jansen, FCS Ramaekers, and AHN Hopman. A novel triple-colour detection procedure for bright-field microscopy, combining in-situ hybridization with immunocytochemistry. J Histochem Cytochem 42, 1299-1307 (1994).

Margriet Snoek, Maurice Jansen, Mark G. Olavesen, R. Duncan Campbell, Cory Teuscher, and Huub van Vugt. Three Hsp70 genes are located in the C4-H-2D region: Possible candidates for the Orch-1 locus. Genomics 15, 350-356 (1993). 


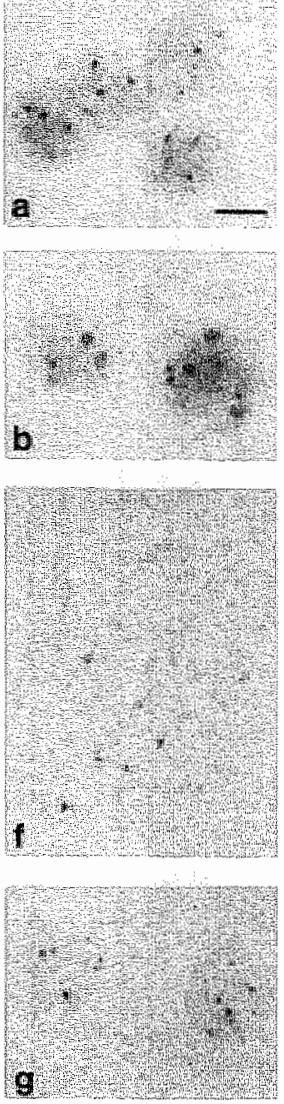
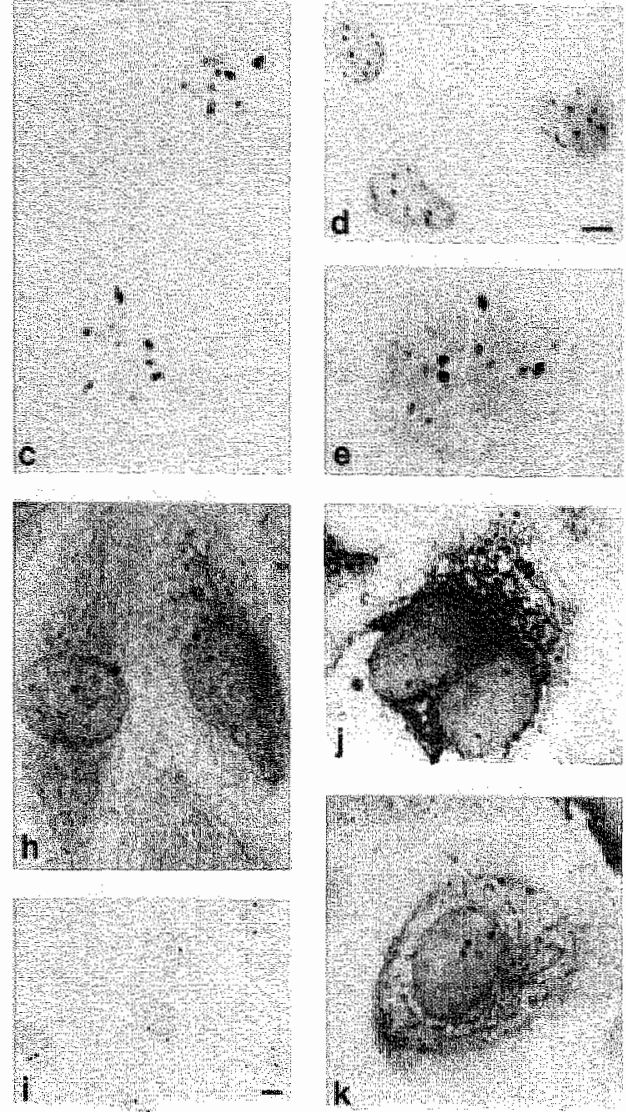

Chapter 2, page 28 - Figure 1. Brightfield detection of (a) single-target, (b,h-j) double-target, and (c-g, $\mathbf{k}$ ) triple-target $1 S H$ in T24 cells (a-e), human lymphocyte metaphase spreads (f-g), and HUVE cells (h-k). Some of these cell preparations were immunocytochemically stained for vimentin before the ISH procedure $(\mathbf{h}, \mathbf{l}, \mathbf{k})$. Nuclei were counterstained with heematoxylin $(\mathbf{a}, \mathbf{b}, \mathbf{d}$ g) or ethyl green (i). DNA probes used were: pUC 1.77 biotin (a) in combination with either $p 1.79$ fluorescein (b) or $p 711$ digoxygenin (h-j), pUC 1.77 biotin in combination with either $\mathrm{p} 7 \mathrm{t}$ fluorescein or $\mathrm{p} 17 \mathrm{HB}$ digoxygenin (c) or $\mathrm{p} 7 \mathrm{t1}$ digoxygenin and $p \| 7 H B$ fluorescein $(d-g, h)$. (a) Detection of the (sub)centromeric regions of chromosome 1 in green (PO-TMB). (b) Detection of the (sub)icentromeric and (sub)telomeric regions of chromosome 1 in brown (PO-DAB) and green (PO-TMB), respectively. (c) Detection of the (sub)centromeric regions of chromosomes 1,7 , and 17 in brown (PO-DAB). green (PO-TMB), and red (APase-Fast Red), respectively, (d-gl) Detection of the (sub) centromeric regions of chromosomes 1,7 , and 17 in brown ( $P O$ DAB), red (APase-Fast Red), and green (PO-TMB), respectively. (h) Sinultaneous detection of the intermediate filament protein vimentin in blue ( $B$-Gal. BClG) and the(sub)centromeric regions of chromosomes 1 and 7 in brown (PO-DAB) and green (PO-TMB). (i) Similar detection of the chromosomal regions as seen in h without ICC staining. (j) Similar ICC-HSH staining as seen in h, except for the (sub) centromeric region of chromosome 7, which is now shown in red (APase-Fast Red). (k) Similar lCC-ISH staining as seen in with the extra detection of the (Sub) centromeric region of chromosome 17 in green (PO-TMB). Bars: $5 \mu \mathrm{m}$. 


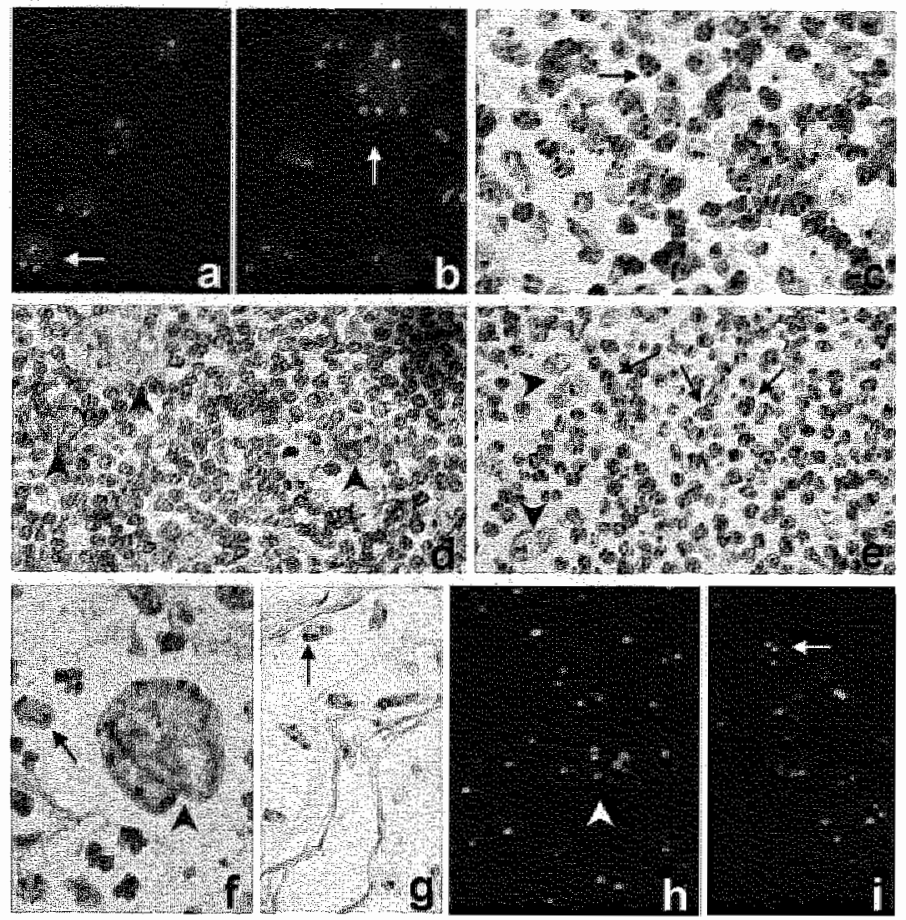

Chapter 4 "page 53 - Figure 2. [a,b] Nuclei isolated from frozen biopsy sample of Hodgkin's disease (nodular sclerosis). In [a] the arrow points to a nucleus with a trisomy for chromosome 1 . The arrow in $[b]$ marks a nucleus that was not evaluated because of the loss of morphology or overlap. This nucleus or nuclei may, however, belong to a Hodgkin or ReedSternberg cell. [c] A $4 \mu \mathrm{m}$ thick paraflin section of Hodgkin's disease (nodular sclerosis) after ISH with chromosome 1 showing a small nucleus with a numerical chromosome abnormality (arrow). [d,e] CD30 positive Hodgkin/Reed-Stemberg cells in $4 \mu m$ thick serial paraffin sections of Hodgkin's disease (nodular sclerosis). Arrow heads indicate Reed-Stemberg cells [d], of which some are also seen in [e]. Black arrows in [e], howewer, show nuclei from morphologically normal cells (see [d]) with a numerical aberration for chromosome 1. [f-i] Bright-fiald and fluorescence ISH on paraffin sections of mixed cellularity Hodghin's disease. Clear differences in morphology and size between nuclei from a Reed-Stemberg cell and a morphologically normal cell (arrow) are illustrated in [f]. Both nuclei have multiple copies for chromosome 4. Figure [g] shows other nuclei from morphologically normal cells with trisomies for chromosome 1 . Finally $[h, i]$ demonstrate chromosomally abnormal nučlei after FISH from Hodgkin/Reed-Stemberg cells (arrow head) [h] and a morphologicaly nomal cell (arrow) [i], respectively. (Magnification $\times 400)$. 


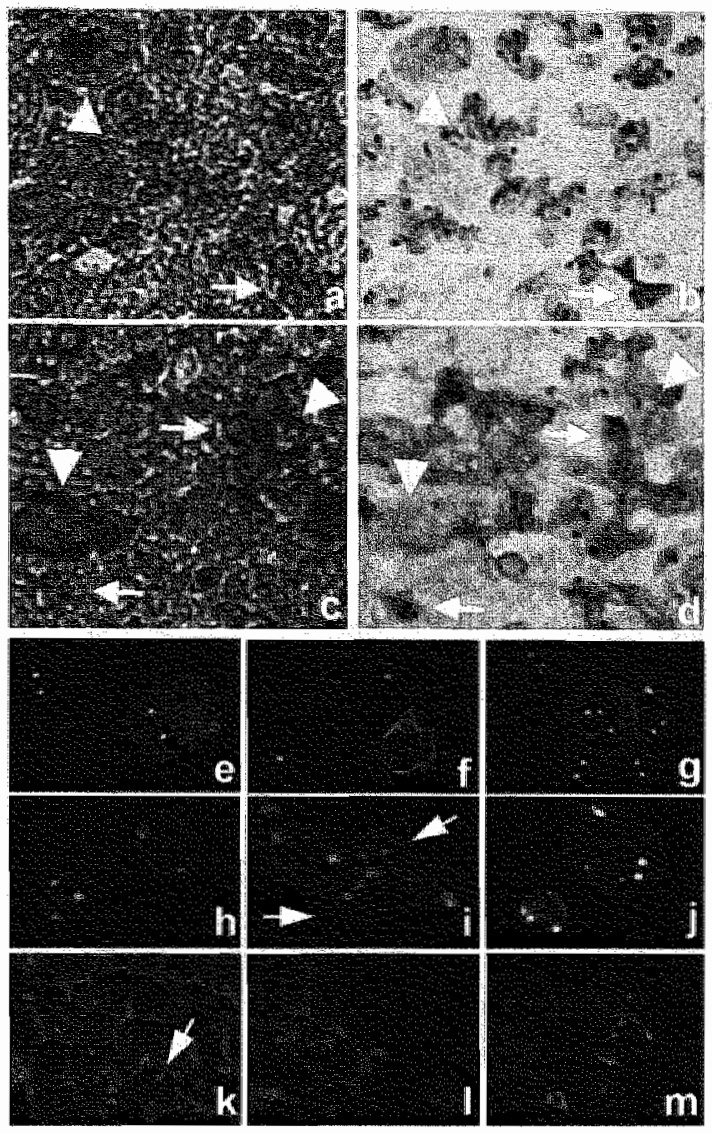

Chapter 5 , page 62 - Figure 1. Paraffin sections of a bone marrow biopsy of Hodgkin's disease (case 1), analyzed for CD30 immunostaining $[\mathbf{a}, \mathbf{c}]$ and numerical aberrations for chromosome 1 with in situ hybridization [b, d]. It is demonstrated in corresponding that numerical chromosome aberrations are not restricted to the CD30 positive Hodgkin/Reed-Sternberg cells (arrowheads), but in. clude asso CD30 negative morphologically normal cells (arirows). Cell suspensions from the second case analyzed with the FICTION technique $[e-g, k-m]$ or with multiple-target fluorescence in situ hybridization (FISH) [h-1]. CD30 positive Hoogkin/Aeed-Stemberg cells (red staining reaction) and CD30 negative morphologically normal cells (arrows) with numerical aberrations for chromosome $X$ (one extra copy) [e], $Y$ chromosome (loss) [1], and chromosome (one extra copy) [g]. Double-target FISH demonstrated numerical abnormalities for only chromosome $X$ (two red signals) but not for the $Y$ chromosome (one green signal) in a morphologically normal cell [h]. Numerical abnormalities for chromosome $X$ (two red signals) and $Y$ (loss of green signal) were also observed in a morphologically normal cell [i]. Triple-target FISH showed numerical aberrations for chromosome X (two red signals), $Y$ (loss of green signal), and 1 (three yellow signais) in a Hodgkin/Reed-Stemberg cell [1]. CD19 positive, morphologically normal cells (red staining reaction) with numerical aberrations for chromosome $X$ (one extra green signal) in a B-cell rich area (arrow) [k], and an area with a low frequency of $B$-lymphocytes $[1, \mathrm{~m}]$. 

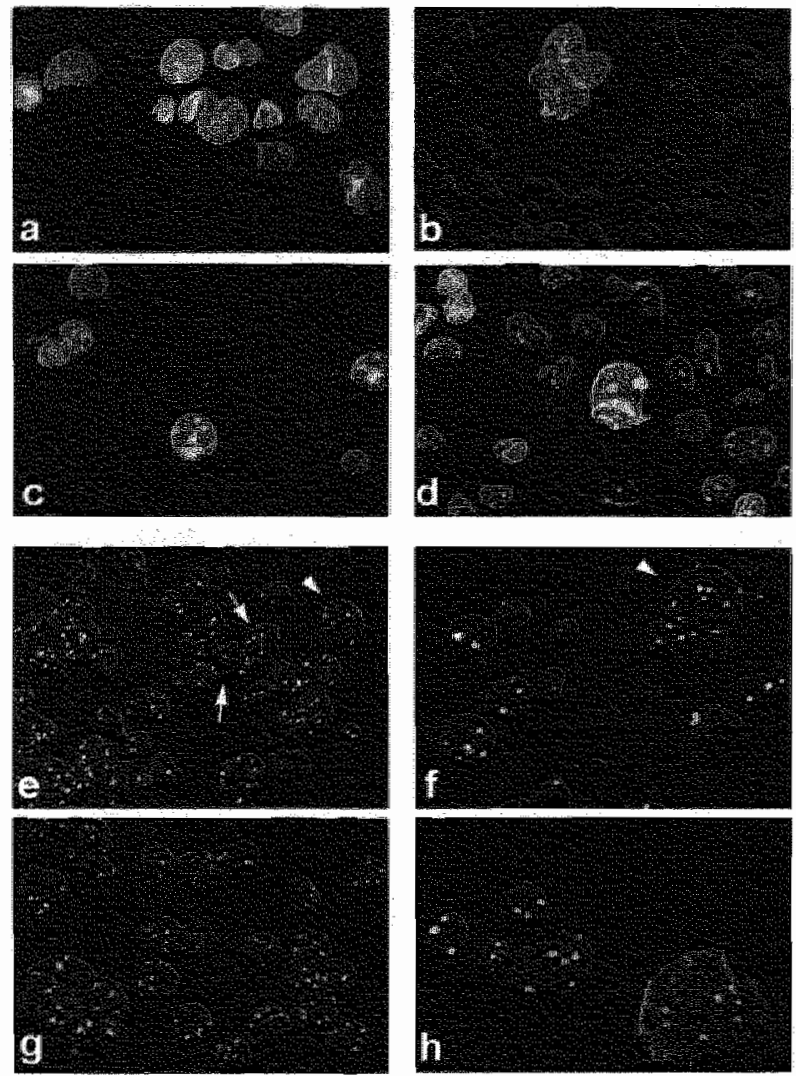

Chapter 6, page 72 - Figure 1. The phenotypic and genetic constitution determined on cytospins of the Hadgkin-derived cell line $\mathrm{L} 1236[\mathrm{a}-\mathrm{d}$, $\mathbf{g}, \mathrm{h}]$ and on paraffin sections from the bone marrow infiltrate of the Hodgkin tumor $[\mathrm{e}, \boldsymbol{\eta}]$. All figures were recorded at a $400 \times$ magnificalion and thereafter processed. [a] Lamin B2 expression as detected with the LN43 antibody, showing that most cells were lamin B2 positive. [b] Lamin A/C expression as detected with the R27 antibody, demonstrating the strong positivity of the large Hodgkin/Reed-Stemberg-like cells. [c] Ki-67 antigen detection with the polyclonal antibody shows both positive as well as negative cells. [d] Combined lamin $\mathrm{A} / \mathrm{C}$ and $\mathrm{Ki}-67$ antigen immunophenotyping demonstrating Hodgkin/Reed-Sternberg-like cells with lamin $\mathrm{A} / \mathrm{C}$ (red) and $\mathrm{Ki}-67$ (green) positivity and small cells with only $K \mathrm{~K}-67$ and/or lamin $\mathrm{A} / \mathrm{C}$ positivity. [e] Numerical abnomalities for chromosomes 1 (green) and 9 (red) as detected with in situ hybridization in morphologically nomal cells (arrows) and in Hodgkin/Reed-Stemberg cells (arrowhead) of the primany tumor [f] A Hodgkin/Reed-Sternberg cell (arrow) of the primary tumor with a polysomy for chromosomes 1 (green) and 9 (red) [g] Chromosome 1 (green) and 9 (red) constitution of the Hodgkin-derived cell line shows predominantly a trisomy for chromosome 1 and a disomy for chromosome 9 . Furthermore, a large multinucleated Reed-Sternberg-like cell with a high copy number for chromosomes 1 and 9. [h] CD30 immunophenotyping showing a CD30 negative Hodgkin-like cell with multiple copies for chromosome 1 and a CD30 positive multinucleated Reed-Stemberg-like cell with different copy numbers in each nucleus for chiromosome 1. 
